Sodium and Protein Nutrition of Lactating Cows under Tropical Conditions

Wandee Thiangtum 


\section{Thesis committee}

\section{Promotor}

Prof. Dr W.H. Hendriks

Professor of Animal Nutrition

Wageningen University \& Research

\section{Co-promotors}

Dr J.Th. Schonewille

Assistant Professor, Department of Farm Animal Health

Utrecht University

Prof. Dr M.W.A. Verstegen

Emeritus Professor of Animal Nutrition

Wageningen University \& Research

\section{Other members}

Prof. Dr B. Kemp, Wageningen University \& Research

Prof. Dr G. Janssens, Ghent University, Belgium

Prof. Dr V. Fievez, Ghent University, Belgium

Dr H. Everts, Utrecht University

This research was conducted under the auspices of the Graduate School of Wageningen Institute of Animal Sciences (WIAS). 


\title{
Sodium and Protein Nutrition of Lactating Cows under Tropical Conditions
}

\author{
Wandee Thiangtum
}

\section{Thesis}

submitted in fulfillment of the requirements for the degree of doctor

at Wageningen University

by the authority of the Rector Magnificus,

Prof. Dr A.P.J. Mol,

in the presence of the

Thesis Committee appointed by the Academic Board

to be defended in public

on Monday 7 May 2018

at 1.30 p.m. in the Aula. 
Wandee Thiangtum

Sodium and Protein Nutrition of Lactating Cows under Tropical Conditions, 124 pages.

$\mathrm{PhD}$ thesis, Wageningen University, Wageningen, the Netherlands (2018)

With references, with a summaries in English and Thai

ISBN 978-94-6343-771-4

DOI http://doi.org/10.18174/445849 


\section{Table of Contents}

Chapter 1

General introduction

Chapter 2

An initial investigation into the relationship between

ration composition and milk production of dairy cows in Thailand: A cross sectional study

Chapter 3

An attempt to define the sodium requirement of lactating dairy cows in a tropical environment

Chapter 4

Response of salivary $\mathrm{Na} / \mathrm{K}$ ratio to changing $\mathrm{Na}$ supply

of lactating cows under tropical conditions

Chapter 5

Effect of dietary protein levels on rumen metabolism

and milk yield in mid-lactating cows under hot and humid conditions

Chapter 6

General discussion

Summary

Acknowledgments

About the author

Curriculum vitae

List of publications 



\section{Chapter 1}

General Introduction 


\section{GENERAL BACKGROUND OF THAI GEOGRAPHY, AGRICULTURE AND THE DAIRY INDUSTRY}

Thailand, a country situated in the heart of southeast Asia, is located between $5^{\circ} 37^{\prime}$ to $20^{\circ} 27^{\prime}$ north latitude and $97^{\circ} 22^{\prime}$ to $105^{\circ} 37^{\prime}$ east longitude (TMD, 2007). The local climate is tropical and characterized by monsoon; from mid-May to September, there is a rainy, warm and cloudy southwest monsoon while from November to mid-March, the northeast monsoon can be characterized as dry and cool. The southern isthmus is hot and humid. The average of minimum and maximum temperature ranges between $24{ }^{\circ} \mathrm{C}$ and $33{ }^{\circ} \mathrm{C}$, respectively (TMD, 2012). Rice is the country's most important crop. Other important agricultural products include fish and fishery products, cassava, rubber, grain and sugar (Falvey, 2000).

Historically, milk has not been an important food product within the Thai culture, and hence there were not many dairy cattle until the second half of the twentieth century (Kehren and Tisdell, 1998). Traditionally, meat from cattle and buffalo was obtained from retired working animals (Murphy and Tisdell, 1995) and surplus income was gained by farmers through the sale of animals for slaughter. In the 1950s, Indian settlers initiated dairying operations in Thailand, with Bangkok as the main market for their milk (Kehren and Tisdell, 1996). The commercial production of dairy cattle in Thailand commenced after the establishment of the Thai Danish Farm and Training Centre at Muek-Lek, which was a joint venture between the Thai and Danish governments in the early 1960s (Pichet, 1991). Another joint venture, the Thai-German Dairy Training and Processing Plant, was established in Chiang Mai in 1968, and this joint venture was taken over by the Thai Department of Livestock Development in 1977. Governmental promotion of milk consumption, in particular for children, resulted in a slow but steady increase in demand throughout the 1970s (ADC, 1993). Despite ongoing governmental actions to promote the dairy industry through various national economic and social initiatives, the dairy industry in Thailand does not yield sufficient milk to support current national demand. The national demand for milk keeps increasing due to an increase of both the population's income and the tourist industry to date. As such, Thailand imports increasing amounts of dairy products from other countries, and milk powder as a substitute for mother's milk, represents a significant proportion of the total import of dairy products. 


\section{DAIRY INDUSTRY IN THAILAND}

To date, there are approximately 512,000 dairy cows in Thailand. The cows are not equally distributed across the country. The majority of the total dairy population $(61 \%)$ is found in the central part of Thailand and $24 \%$ in the northeastern part (Isan) of the country. Virtually all of the remaining cows of the Thai dairy population are found in the northern part of Thailand because only $1 \%$ of the population lives in the southern part of Thailand (DLD, 2014). Almost all dairy cows are Holstein Friesian crossbreds (87.5\% HF) (Koonawootrittriron, 2014). Practically $95-99 \%$ of the dairy cow in Thailand are kept by small scale or small-holder farmers under mixed crop-livestock farming system (Chantalakhana and Skunmun, 2002; Wanapat, 1995). Typically, most dairy farmers in Thailand (59.9\%) are small holders managing on average of 30 dairy cows per farm (DLD, 2014). There are a small number of farms $(23.8 \%)$ with a herd size of 11 to 20 dairy cows and only $16.3 \%$ of the dairy farmers manage less than 11 dairy cows (DLD, 2014). Thai farmers keep their dairy cows in two types of housing systems, the tie-stall barn or a loose-stall barn system. The tie-stall barns are mainly used in the central and northern part of Thailand whereas loose-stall barns are typically used in the northeastern part of Thailand (i.e. Isan). Thai dairy cows produce 3733 $\mathrm{kg}$ per lactation, and daily milk yield averages $12.2 \mathrm{~kg} / \mathrm{cow}$ (Pattamanont and Ruengpaibul, 2015). The mean composition of milk is $3.71 \%$ fat, $3.03 \%$ protein, $4.70 \%$ lactose, $8.43 \%$ nonfat solids and $12.13 \%$ total solids (Kamphusiri, 2013).

\section{GENERAL NUTRITION OF THAI DAIRY COWS}

In general, Thai dairy farmers own a small amount of land averaging $<1$ ha (Kummanee $e t$ al., 2012; Sompakdi and Phonprapai, 2014; Suriya, 2015) which hampers the possibility to graze cows on pastures. Therefore, the feeding of fresh grass is usually based on a cut and carry system; i.e. the grasses are manually collected from publically available land and fed to the cows on the same day. Grasses such as Ruzzi grass (Bracharia ruziziensis), Para grass (Bracharia mutica), Napier grass (Pennisetum purpureum), Guinea grass (Panicum maximum) and Pangola (Digitaria eriantha) are among the species most commonly used. In practice, the feeding of fresh grasses is restricted to the rainy season and given the labor intensive method of collection, quantitatively less important than roughage sources originating from agricultural activities such as cropping of rice, corn, cassava and sugar cane. In quantitative terms, the roughage supply typically depends on the availability of agricultural waste or by-products. Next to the fore mentioned roughages, concentrates also are widely used but regional differences exist on the use of compound feeds. For instance, in the north- 
east of Thailand, farmers prefer on farm mixing of single, non-pelleted, feedstuffs while in the north and central part of Thailand, the use of pelleted compound feeds is more common. Feedstuffs used as concentrates are mainly agro-industrial and industrial by-products such as cassava chips, cassava pulp, soybean hull, pineapple waste, tomato waste, potato waste, molasses and distiller's grain waste. In principle, the farmers feed concentrates twice daily during milking while roughage is offered ad libitum. Computerized optimization of dairy rations is hardly practiced in Thailand and the amount of concentrate offered to the cows is calculated on the basis of the cow's milk yield. A commonly applied rule is the supply of $1 \mathrm{~kg}$ of concentrate for each $2 \mathrm{~kg}$ of milk produced (Wanapat et al., 2000).

\section{CONSTRAINTS OF DAIRY PRODUCTION IN THAILAND}

Milk production is determined by both genetic and environmental factors and it was estimated by Wachirapakorn (2003) that $70 \%$ of the variation in milk production is explained by environmental factors, including nutrition. As already mentioned before, almost all dairy cows in Thailand are Holstein Friesian crossbreds. In view of such genetic merit of the Thai dairy cows, it is generally accepted that current milk yields are below the potential of these cows. Consequently, the main reason for the low milk production of dairy cows is related to the prevailing environmental conditions. The tropical climate is an important constraint for milk production because of two main reasons. First, it is well known that the digestibility of forages is negatively affected by tropical conditions. Tropical forages mature more rapidly than temperate forages (Leng, 1995). Unfavorable growth conditions can result in low contents of protein and minerals in the plant and high amounts of so called structural carbohydrates, i.e. neutral detergent fibre (NDF), acid detergent fibre (ADF) and acid detergent lignin (ADL). Especially the high ADF and ADL contents of tropical feedstuffs (Table 1) cause a poor digestion.

Next to the negative impact of tropical conditions on the nutritional quality of the forages, it is well known that during heat stress, feed intake and thus production performance, is reduced (McDowell, 1972; Rhoads et al., 2009). Various strategies such as nutrition management schemes, physical protection and genetic development can be implemented to alleviate heat stress under hot and humid conditions. Although the relevance of this topic cannot be disputed, it is beyond the scope of the current thesis. 
Table 1. Nutrient composition of roughages commonly used in Thailand

\begin{tabular}{|c|c|c|c|c|c|c|c|c|c|}
\hline \multirow[t]{2}{*}{ Item } & $\mathrm{DM}$ & Ash & $\mathrm{CP}$ & $\mathrm{EE}$ & $\mathrm{NDF}$ & $\mathrm{ADF}$ & ADL & NFC & $\mathrm{Na}$ \\
\hline & \multicolumn{3}{|l|}{$(\%$ as fed $)$} & \multicolumn{3}{|c|}{ (\% of DM) } & & & \\
\hline \multicolumn{10}{|l|}{ Grasses and leaves } \\
\hline Brachiaria mutica & 20.7 & 13.7 & 7.5 & 2.9 & 63.4 & 38.7 & 3.6 & 12.5 & 0.02 \\
\hline Brachiaria ruziziensis & 21.6 & 8.2 & 9.0 & 2.4 & 64.3 & 35.2 & 8.1 & 16.1 & $<0.01$ \\
\hline Digitaria eriantha & 18.9 & 12.1 & 8.2 & 2.4 & 63.1 & 38.5 & 3.5 & 14.2 & 0.03 \\
\hline Panicum maximum & 19.5 & 5.5 & 12.5 & 2.4 & 70.1 & 43.5 & 7.8 & 9.5 & 0.04 \\
\hline Pennisetum purpureum & 18.1 & 5.4 & 12.0 & 2.7 & 63.2 & 39.1 & 6.1 & 16.7 & $<0.01$ \\
\hline Dried cassava leaves & 90.2 & 9.0 & 25.6 & 5.9 & 30.7 & 27.0 & 26.4 & 28.8 & - \\
\hline \multicolumn{10}{|l|}{ Dried Leucaena } \\
\hline leucocephala & 90.7 & 6.9 & 22.4 & 3.2 & 31.2 & 21.7 & 10.8 & 36.3 & - \\
\hline \multicolumn{10}{|l|}{ Centrosema pascuorum } \\
\hline cv. Calvacade & 22.6 & 8.7 & 10.3 & 2.4 & 59.8 & 41.2 & 8.0 & 18.8 & 0.05 \\
\hline \multicolumn{10}{|l|}{ Crop residues } \\
\hline Rice straw & 93.5 & 14.1 & 3.0 & 1.9 & 74.7 & 53.2 & 4.5 & 6.3 & 0.01 \\
\hline Sweet corn stem & 26.1 & 6.2 & 6.7 & 2.3 & 63.6 & 38.8 & 5.4 & 21.2 & $<0.01$ \\
\hline Sweet corn cop & 25.2 & 7.0 & 5.2 & 1.5 & 39.4 & 34.6 & 5.0 & 46.9 & $<0.01$ \\
\hline Sweet corn husk & 26.0 & 4.0 & 5.9 & 1.3 & 70.0 & 36.0 & 4.2 & 18.8 & $<0.01$ \\
\hline Baby corn husk & 14.0 & 2.2 & 12.6 & 1.8 & 50.5 & 24.3 & 3.5 & 32.9 & $<0.01$ \\
\hline Baby corn stem & 18.3 & 6.0 & 8.9 & 2.5 & 58.6 & 29.6 & 4.6 & 24.0 & 0.02 \\
\hline Pineapple waste & 13.0 & 4.2 & 5.8 & 3.9 & 59.4 & 27.9 & 2.2 & 26.7 & 0.01 \\
\hline Sugar cane (top) & 91.3 & 6.5 & 4.0 & 1.1 & 71.3 & 42.5 & 3.4 & 17.1 & - \\
\hline
\end{tabular}

DM, dry matter; CP, crude protein; EE, ether extract; NDF, neutral detergent fibre; ADF, acid detergent fibre; ADL, acid detergent lignin; NFC, non-fibre carbohydrate (NFC = $100-$ ash - CP EE - NDF); Na, sodium. Adapted from Kanjanapruthipong (2006).

Due to the low digestibility of the roughages, the use of concentrates is necessary to ensure dairy productivity (Wanapat et al., 2000). The use of energy rich concentrates counteracts, at least partly, the low digestible energy content of roughages but it was already mentioned that the commonly used roughages also have low protein contents. Consequently, the concentrates to be used should also have a high protein content to ensure adequate protein supply of the cows. However, the majority of Thai farmers are small holders and they typically have a small margin between daily income and expenses in terms of liquid assets. Therefore, these farmers are reluctant to purchase protein rich concentrates because protein is relatively expensive (Kehren and Tisdell, 1998). 
Since Thai dairy cows reduce their voluntary intake during heat stress, it is logical that mineral intake is less than optimal relative to potential productivity. Sodium is the major element in saliva and is utilized to buffer acid from ruminal fermentation. Sodium requirements and production responses are affected by temperature, humidity, sweating rate, stage of lactation, gestation, growth, and level of production (Suttle, 2010). Sweating aids in heat dissipation, and $\mathrm{Na}$ and $\mathrm{K}$ are secreted in sweat which sits on the surface of the skin. Sweat from the skin surface has a cooling effect due to evaporative cooling. The conversion of liquid water into vapor uses the thermal energy in the air, resulting in a lowering of the temperature of the skin. As a result, dilated blood vessels in the skin can lose heat more effectively to the surrounding air which subsequently reduces the body temperature. In unacclimatised cattle, the dribbling of saliva and sweating can result in daily losses of $\mathrm{Na}$ (Aitken, 1976; Collins and Weiner, 1968). In heat stressed dairy cows, supplementation of Na resulted in a significant increase in milk production (Schneider et al., 1984, 1986). Forages contain relatively small amounts of $\mathrm{Na}$ (Table 1) due to soil, plant and husbandry factors (Suttle, 2010). The distribution of pasture Na concentrations worldwide is skewed towards low values, with $50 \%$ of samples containing $<0.15 \%$ of $\mathrm{Na}$; moreover ever lower values are more common in tropical than in temperate pasture: tropical legume contain $<0.04 \%$ of $\mathrm{Na}$ (Minson, 1990).

\section{AIM OF THE THESIS}

The overall objective of the research described in this thesis was to provide a basis for improvement in milk production by dairy cows on small farm holders in Thailand. First a cross sectional study was conducted on farms varying in type and the amount of roughage supply to dairy cows on its effect to milk production (Chapter 2). This research led to indications of a low $\mathrm{Na}$ and protein supply on these farms and subsequent studies were conducted to investigate these nutritional aspects. In Chapter 3, the $\mathrm{Na}$ requirement of lactating dairy cows housed under tropical conditions was addressed while in Chapter 4 the physiology response of $\mathrm{NaCl}$ depletion and repletion was determined in lactating dairy cow under tropical conditions. The effect of concentrates with two levels of protein (17 and 21\%) and the influence on rumen metabolism and milk production in mid lactating cows is reported (Chapter 5). Finally, the results of the studies are summarized and discussed in Chapter 6. 


\section{REFERENCES}

Aitken, F. C. 1976. Sodium and Potassium in Nutrition of Mammals. Commonwealth Bureau of Nutrition. Tech. Comm. No.26.

Australian Dairy Corporation (ADC). 1993. Thailand, Dairy Market Briefings. ADC, Melbourne.

Chantalakhana, C. and P. Skunmun. 2002. Sustainable Smallholder Animal Systems in the Tropics. Kasetsart University Press, Bangkok, p. 302 (in Thai).

Collins, K. J. and J. S. Weiner. 1968. Endocrinological aspects of exposure to high environmental temperatures. Physiol. Rev. 48:785-839.

Department of Livestock Development (DLD). 2014. Data of the number of farmer and dairy cows, in The Number of Livestock in Thailand. Information and statistics group, Department of Livestock Development, Bangkok, pp. 36-48 (in Thai).

Falvey, L. 2000. Thai Agriculture - Golden Cradle of Millennia. Kasetsart University Press, Bangkok, pp. 3-4.

Kamphusiri, N. 2013. Milk Quality Control of Raw Milk in Thailand. Milk and milk product quality control division, Bureau of quality control of livestock product, Department of Livestock Development. Available at http://certify.dld.go.th/th/images/executive/2557/April/21042556/1/04.pdf. Downloaded on August 26, 2016.

Kanjanapruthipong, J. 2006. Dairy Herd Management. Kasetsart University Press, Thailand, p. 230 (in Thai).

Kehren, T. and C. A. Tisdell. 1996. Women and common property resources in the management and health of livestock in Thai villages. Research Papers and Reports in Animal Health Economics, No. 24. The University of Queensland, Brisbane.

Kehren, T. and C. A. Tisdell. 1998. The Thai dairy industry: Its economic evolution and problems raised by land rights and cattle diseases. J. Asia Pacific Econ. 3:1-20.

Koonawootrittriron, S. 2014. Genetic structure of dairy cow in Thailand. Available at http://www.tagu.nisit.ku.ac.th/index.php/issue/90-crossbred-f1. Downloaded on May $24,2016$.

Kummanee, K., N. Intasiri, J. Thunggern and N. Yimsook. 2012. Basic factors related to the effectiveness of the dairy farmer cooperative: A case study in the members of Kamphaeng Sean dairy cooperative, Limited. J. Soc. Sci. Liberal Arts 1:21-28. 
Leng, R. 1995. Appropriate technologies for field investigation in ruminant livestock nutrition in developing countries, in Agricultural Sciences for Biodiversity and Sustainability in Developing Countries, Proceedings of a Workshop. Tune Landbskole, Denmark, pp. 57-77.

McDowell, R. E. 1972. Improvement of Livestock Production in Warm Climates. W. H. Freeman and Company, San Francisco, California.

Minson, D. J. 1990. Forages in Ruminant Nutrition. Academic Press, San Diego, California, pp. 208-229.

Murphy, T. and C. A. Tisdell. 1995. Specific livestock industries, livestock diseases and policies in Thailand: an overview of bovines (buffalo/cattle), Research Papers and Reports in Animal Health Economics, No. 10. The University of Queensland, Brisbane, Australia.

Pattamanont, P. and S. Ruengpaibul. 2015. Fertility and milk production of dairy cattle rearing in good management farm, Research Paper Number 58(2)-0211-006. Bureau of livestock extension and development. Bangkok, Thailand (in Thai).

Pichet, S. 1991. The development of dairy farming in Thailand, in Feeding Dairy Cows in the Tropics, Proceedings of the FAO Expert Consultation. Bangkok, Thailand.

Rhoads, M. L., R. P. Rhoads, M. J. VanBaale, R. J. Collier, S. R. Sanders, W. J. Weber, B. A. Crooker and L. H. Baumgard. 2009. Effects of heat stress and plane of nutrition on lactating Holstein cows: I. Production, metabolism, and aspects of circulating somatotropin. J. Dairy Sci. 92:1986-1997.

Schneider, P. L., D. K. Beede and C. J. Wilcox. 1986. Responses of lactating cows to dietary sodium source and quantity and potassium quantity during heat stress. J. Dairy Sci. 69:99-110.

Schneider, P. L., D. K. Beede, C. J. Wilcox and R. J. Collier. 1984. Influence of dietary sodium and potassium bicarbonate and total potassium on heat-stressed lactating dairy cows. J. Dairy Sci. 67:2546-2553.

Sompakdi, C. and C. Phonprapai. 2014. Readiness and requirements of dairy farmers in the operational area (Northern region) of the dairy farming promotion organization of Thailand in approaching Thai agricultural standard for organic livestock. Thai J. Sci. Tech. 3:182-195 (in Thai).

Suriya, P. 2015. A comparison on economic costs and returns of raw milk production by dairy farm standards in Pak Chong district, Nakhon Ratchasima province. Khon Kaen Agr. J. 43:101-110. 
Suttle, N. F. 2010. Sodium and chloride, in The Mineral Nutrition of Livestock (4th edn). CABI, London, UK, pp. 182-205.

Thai Meteological Department (TMD). 2007. Thailand Geographic and Regional Classification (TMD, Thailand). Available at http://www.tmd.go.th/info/info.php?FileID=51. Downloaded on January 20, 2009.

Thai Meteorological Department (TMD). 2012. Annual Mean Temperature in Thailand. Available at http://www.tmd.go.th/climate/climate.php?FileID=7. Downloaded on December 16, 2012.

Wachirapakorn, C. 2003. Nutrition management of dairy cow on milk production and milk composition, in The Quality of Milk to Consumer. Khon Kaen, Thailand, pp. 14 (in Thai).

Wanapat, M. 1995. Nutrition strategies based on crop-residues to increase swam buffalo production and draft efficiency on farms, in Proceedings of an International Workshop on Draft Animal Power. Khon Kaen, Thailand.

Wanapat, M., O. Pimpa, A. Petlum, C. Wachirapakorn and C. Yuanklang. 2000. Particpation scheme of smallholder dairy farmers in the Northeast Thailand on improving feeding systems. Asian-Aus. J. Anim. Sci. 13:830-836. 


\section{Chapter 2}

\section{An Initial Investigation into the Relationship between Ration Composition and Milk Production of Dairy Cows in Thailand: A Cross Sectional Study}

Wandee Thiangtum $^{1}$, J Thomas Schonewille ${ }^{2,3}$, Adisorn Yawongsa ${ }^{1}$, Theera Rukkwamsuk ${ }^{1}$, Martin WA Verstegen ${ }^{4}$ and Wouter H Hendriks ${ }^{2,4}$

\footnotetext{
${ }^{1}$ Department of Large Animal and Wildlife Clinical Sciences, Faculty of Veterinary Medicine, Kasetsart University, Thailand

${ }^{2}$ Department of Farm Animal Health, Faculty of Veterinary Medicine, Utrecht University, The Netherland

${ }^{3}$ Department of Agricultural Technology and Environment, Faculty of Sciences and Liberal Arts, Rajamangala University of Technology Isan, Thailand

${ }^{4}$ Department of Animal Sciences, Wageningen University, The Netherlands
} 


\begin{abstract}
The current study was conducted as a preliminary investigation into the relationship between ration composition and milk production in dairy cows in Thailand. A total of 45 multiparous cows (4-7 per farm) were monitored at $70(n=33)$ and at 130 days $(n=30)$ after calving. Body weight, milk yield and composition and feed intake as well as feed composition of each cow were determined. Cows fed with rations rich in crude protein (CP) and non-fibre carbohydrates (NFC) tended to have higher milk yields. Milk yield was inversely related with the forage to concentrate ratio and the dietary levels of neutral detergent fibre. Cows consumed 5 and $8 \%$ greater $\mathrm{CP}$ than requirement during early- and mid-lactation, respectively. Nevertheless, cows that ingested more CP responded with more milk yield, both during early- and mid-lactation. Intake of net energy for lactation $\left(\mathrm{NE}_{\mathrm{L}}\right)$ in early lactation was $5 \%$ lower than recommended while $\mathrm{NE}_{\mathrm{L}}$ intake during mid lactation was $14 \%$ greater than required. During early- but not mid-lactation, milk production responded positively to greater intakes of $\mathrm{NE}_{\mathrm{L}}$. The current observations are considered important with regard to dietary interventions to improve milk production in Thailand.
\end{abstract}




\section{INTRODUCTION}

The level of dairy milk production in Thailand is low, averaging 12 and $13 \mathrm{~kg} / \mathrm{d}$ (DLD, 2011). The low level of milk production is most likely not caused by a poor genetic potential for milk production, because the dairy cows are generally crossbreds between Holstein-Friesian (> $87.5 \%) \times$ indigenous breed. It is estimated that the milk yield of Thai dairy cows is only $50 \%$ of their potential to produce milk (Tumwasorn et al., 1997).

Clearly, the normal Thai climatological conditions (average maximum temperature $33{ }^{\circ} \mathrm{C}$, minimum temperature $27^{\circ} \mathrm{C}$ and relative humidity $72-74 \%$ ) do not facilitate a high dry matter intake (DMI) and thus not a high milk production (Rhoads et al., 2009). In addition, the feeding value of roughages to dairy cows in Thailand is low because of low digestibility and this can be considered a major constraint in relation to DMI (Leng, 1995). The various sources of roughage that are typically used in Thailand include crop residues (rice straw, corn stem, corn sheath, corn silk, pineapple peal, etc.) and grasses (Mauritius sp., Panicum maximum TD58, etc.). In general, the crop residues are low both in digestible energy and protein content (Balch, 1976). Furthermore, the quality of the grass is low due to a high content of lignin and low protein content (Leng, 1995). It is well known that at high environmental temperatures, the provision of poor quality roughage further lowers feed intake (Leng, 1995), leading to low levels of milk production. Therefore, roughages are supplemented with concentrates to support milk production. Under practical Thai conditions, the amount of concentrate fed to the cows is determined by the amount of milk produced; approximately $1 \mathrm{~kg}$ of concentrate is provided for each $2 \mathrm{~kg}$ of milk produced.

Besides the low energy and protein contents, vegetable feed compounds contain small amounts of sodium $(\mathrm{Na})$. The amount of $\mathrm{Na}$ present in feed composed from these compounds may not be sufficient under tropical conditions. Furthermore, the current NRC (2001) requirements of $\mathrm{Na}$ for lactation cattle $(0.22 \%$ in the $\mathrm{DM})$ may not be valid under the conditions where the animal experiences heat stress (Sanchez et al., 1994). It was suggested by Schneider et al. (1986), that feeding supplemental Na may increase milk production under heat stress conditions. To achieve a more optimal performance of dairy cows in Thailand, knowledge on the composition of the feedstuffs and the rations is essential as these data can improve the formulation of appropriate rations for dairy cows. Currently, the available data regarding the relationship between ration and milk production on Thai dairy farms are limited. A cross sectional survey was, therefore, conducted on farms in Thailand which varied in type 
and amount of roughage supplied to dairy cows with both feed and milk samples collected and analysed. It was anticipated that this study would provide a first insight into the potential to improve milk production on Thai farms with the use of local feedstuffs.

\section{MATERIALS AND METHODS}

\section{Animals and feeding}

In the current study healthy, multiparous crossbred Holstein-Friesian cows housed at six different dairy farms in Thailand were used. The average size of the herd was $49 \pm 17$ cows. Four to seven multiparous cows per farm between the $2^{\text {nd }}$ to $4^{\text {th }}$ parity were selected with 33 cows being, on average, $70 \pm 10$ days in milk (DIM) and 30 cows $130 \pm 17$ DIM. Eighteen cows were followed during both early- and mid-lactation. Each farm was visited once or twice to monitor milk performance, feed intake and nutrient composition of the rations.

Table 1. Climatological indices and characteristics of the Thai farms included in the study

\begin{tabular}{ccccccc}
\hline \multicolumn{2}{c}{ Farm No cows } & Concentrate type & Roughage type & T $\left({ }^{\circ} \mathrm{C}\right)$ & $\mathrm{RH}(\%)$ & $\mathrm{THI}$ \\
\hline A & 46 & Commercial & Urea treated rice straw, Ruzi hay and Panicum & 25 & 67 & 71 \\
& & & maximum TD58 \\
B & 41 & Commercial & Pineapple peal and Panicum maximum TD58 & 27 & 79 & 78 \\
C & 44 & Farm-made & Rice straw & 31 & 68 & 83 \\
D & 32 & Commercial & Baby corn stem, baby corn husk and rice straw & 29 & 79 & 81 \\
E & 49 & Commercial & Baby corn husk and Centrosema pascuorum cv. & 30 & 73 & 82 \\
& & & Cavalcade & & & \\
F & 83 & TMR & Total mixed ration & 26 & 73 & 76 \\
\hline
\end{tabular}

$\mathrm{T}$, average temperature; $\mathrm{RH}$, relative humidity; THI, temperature humidity index.

The participating farms were similar in farm management in terms of milking and feeding but used various feedstuffs (Table 1). During the study period, the farmers did not change the type of roughage used while the amount of concentrate was adjusted to milk yield and lactation period. The cows were housed in tie stall barn throughout the lactation period and had free access to water. The concentrates were given twice daily in two similar portions during milking times $(\sim 05: 30$ and $\sim 15: 00 \mathrm{~h})$. The roughage was offered after the concentrate was consumed except for the 4 cows on farm $F$ that received a total mixed ration (TMR). 
Feeds offered and feed refusals were recorded per individual cow throughout $24 \mathrm{~h}$ and used to calculate feed intake. Each farm used a milking machine and milk yields of individual cows were recorded at each milking.

\section{Sampling and laboratory analyses}

Concentrate and roughage samples were collected on the same day as feed intake was determined. Feedstuffs were dried to constant weight in a forced air oven at $60{ }^{\circ} \mathrm{C}$ and then allowed to equilibrate to the air. The dried feed samples were ground to pass a $1 \mathrm{~mm}$ sieve and stored at $5{ }^{\circ} \mathrm{C}$ until chemical analysis. Dry matter (DM), ash, crude protein (CP) and ether extract (EE) were analysed according to the AOAC (1990). Neutral detergent fibre (NDF) and acid detergent fibre (ADF) were analysed following the method of Van Soest et al. (1991). Total digestible nutrients (TDN) of all roughages and that of the farm made concentrates on farms $\mathrm{C}$ and $\mathrm{F}$ were calculated from the ingredients in the ration based on the Thai nutrient composition table (Kanjanapruthipong, 2006). The feed company provided the TDN values of the commercial concentrates. The non-fibre carbohydrates (NFC) content of concentrates was calculated as $100 \%$ minus the percentages of ash, CP, EE, and NDF in dry matter. Sodium was measured by flame emission spectroscopy (AA-6800, Shimadzu, Kyoto, Japan).

Milk samples were collected at the two consecutive milking times for determination of milk composition. Milk samples were placed in bottles containing $0.024 \%$ (w/v) of sodium azide and stored at $5{ }^{\circ} \mathrm{C}$ for $\leq 3$ days until analysis of fat, protein, lactose and non-fat solids by the infrared method (Bentley, 2000, Agriyork Ltd. UK).

Body weight of the cows was determined by heart girth measurement (chest circumference) using a weight band (Heinrichs et al., 1992). Body condition score was determined on a scale of 1 to 5 with 1 (emaciated) to 5 (obese) based on Edmonson et al. (1989). Body weights were determined $2 \mathrm{~h}$ after feeding in the morning on the day that feed intake and milk yield were recorded. 


\section{Statistical analyses}

Overall effect of farm on the parameters (milk yield, milk composition, DM intake of feed and feed composition variable) was tested for significance by the use of one way ANOVA in the GLM procedure of SAS (SAS Inst. Inc., Cary, NC, USA). The statistical model was:

$$
\mathrm{Y}=\mu+\operatorname{Farm}_{\mathrm{i}}+\varepsilon_{\mathrm{ij}}
$$

where $\mathrm{Y}=$ parameter to be tested, $\mu=$ mean, Farm $_{\mathrm{i}}=$ effect of farm $\mathrm{i}$, and $\varepsilon_{\mathrm{ij}}=$ error term. For each parameter, differences among means of farms were tested for significance by ANOVA using the Tukey multiple range test. The normality and independent assumptions of $\varepsilon_{\mathrm{ij}}$ were confirmed through residuals analysis and no indication of model inadequacy was found.

Pearson correlations between milk yield $(\mathrm{kg} / \mathrm{d})$ and $\mathrm{CP}$ intake $(\mathrm{kg} / \mathrm{d}), \mathrm{NDF}$ intake $(\mathrm{kg} / \mathrm{d}), \mathrm{NFC}$ intake $(\mathrm{kg} / \mathrm{d}), \mathrm{EE}$ intake $(\mathrm{kg} / \mathrm{d})$ and $\mathrm{Na}$ intake $(\mathrm{g} / \mathrm{d})$ were calculated using the CORR procedure of SAS (SAS Inst. Inc., Cary, NC, USA). Throughout, the level of statistical significance was pre-set at $P<0.05$.

\section{RESULTS}

\section{Feed composition, forage to concentrate ratio and nutrient intake}

At 70 days in milk

The total $\mathrm{CP}$ content of the rations ranged from 10.5 to $26.3 \%$ of DM (Table 2). The ration provided to the cows on farm F contained the highest dietary CP content and these cows had the highest total CP intake (Table 3). Although the lowest dietary CP content was observed on farm $\mathrm{A}, \mathrm{CP}$ intake was similar to the cows on farm $\mathrm{C}$ due to the greater DM intake. The cows on farms $\mathrm{C}$ and $\mathrm{E}$ received a ration with a similar dietary $\mathrm{CP}$ content and their protein intakes were similar to that of cows on farms A and D. The highest mean EE intake was observed on farm B while the lowest EE intake was observed at farms A, D and F, which is in line with the dietary EE contents on these farms. The percentage of NFC was the lowest on farm A while cows on farms D and E had the highest \% of NFC in their ration. Taking differences in DM intake into account, the cows at farms D, E and F ingested the highest amounts of NFC while NFC intake was lowest at farms A and B. The NDF contents of the ration were similar on farms B, D and E. Rations containing the lowest and highest NDF contents were fed on farms $\mathrm{F}$ and A, respectively. However, NDF intake was only significantly different on farm A. The forage to concentrate ratio of the ration was similar on farms B, C, D and F and highest on 
farm A. The TDN intake was significantly different between farms $\mathrm{C}$ and $\mathrm{F}$. The dietary $\mathrm{Na}$ content ranged from 0.11 to $0.39 \%$ of DM with the lowest dietary Na content was observed on farm $\mathrm{A}$, which was reflected in the low $\mathrm{Na}$ intake of the cows on this farm. However, $\mathrm{Na}$ intake by the cows on farm A was similar to those on farm D.

Table 2. Feed composition and forage to concentrate ratio (F/C) provided to cows at 70 and 130 days in milk at six Thai farms

\begin{tabular}{|c|c|c|c|c|c|c|c|c|c|}
\hline \multirow[t]{2}{*}{ Farm } & \multicolumn{8}{|c|}{ 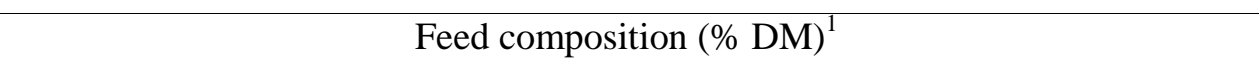 } & \multirow[t]{2}{*}{$\mathrm{F} / \mathrm{C}$} \\
\hline & $\mathrm{CP}$ & $\mathrm{EE}$ & NFC & $\mathrm{CF}$ & $\mathrm{NDF}$ & ADF & TDN & $\mathrm{Na}$ & \\
\hline \multicolumn{10}{|c|}{70 days in milk } \\
\hline A & $10.5^{\mathrm{e}}$ & $2.9^{c}$ & $16.7^{\mathrm{c}}$ & $29.5^{\mathrm{a}}$ & $56.3^{\mathrm{a}}$ & $37.4^{\mathrm{a}}$ & $0.56^{\mathrm{a}}$ & $0.11^{\mathrm{a}}$ & $2.28^{\mathrm{a}}$ \\
\hline $\mathrm{B}$ & $18.7^{\mathrm{b}}$ & $7.2^{\mathrm{a}}$ & $26.4^{\mathrm{b}}$ & $15.5^{\mathrm{c}}$ & $37.2^{\mathrm{c}}$ & $19.2^{\mathrm{cd}}$ & $0.71^{\mathrm{d}}$ & $0.39^{\mathrm{d}}$ & $0.54^{\mathrm{c}}$ \\
\hline $\mathrm{C}$ & $13.5^{\mathrm{d}}$ & $3.8^{\mathrm{b}}$ & $28.7^{\mathrm{b}}$ & $18.9^{\mathrm{b}}$ & $45.0^{\mathrm{b}}$ & $26.1^{\mathrm{b}}$ & $0.63^{\mathrm{b}}$ & $0.34^{\mathrm{d}}$ & $0.51^{\mathrm{c}}$ \\
\hline $\mathrm{D}$ & $16.2^{\mathrm{c}}$ & $2.5^{\mathrm{cd}}$ & $33.8^{\mathrm{a}}$ & $16.0^{\mathrm{bc}}$ & $37.4^{\mathrm{c}}$ & $21.3^{\mathrm{c}}$ & $0.69^{\mathrm{d}}$ & $0.18^{\mathrm{b}}$ & $0.80^{\mathrm{bc}}$ \\
\hline $\mathrm{E}$ & $13.0^{\mathrm{d}}$ & $4.5^{\mathrm{b}}$ & $34.6^{\mathrm{a}}$ & $18.0^{\mathrm{bc}}$ & $40.5^{\mathrm{bc}}$ & $20.7^{\mathrm{cd}}$ & $0.70^{\mathrm{d}}$ & $0.27^{\mathrm{c}}$ & $1.43^{\mathrm{b}}$ \\
\hline $\mathrm{F}$ & $26.3^{\mathrm{a}}$ & $2.1^{\mathrm{d}}$ & $27.5^{\mathrm{b}}$ & $16.3^{\mathrm{bc}}$ & $30.7^{\mathrm{d}}$ & $18.0^{\mathrm{d}}$ & $0.66^{\mathrm{c}}$ & $0.24^{\mathrm{c}}$ & $0.47^{\mathrm{c}}$ \\
\hline SEM & 0.82 & 0.33 & 1.06 & 0.87 & 1.41 & 1.15 & 0.01 & 0.02 & 0.13 \\
\hline \multicolumn{10}{|c|}{130 days in milk } \\
\hline A & $11.8^{\mathrm{c}}$ & $3.1^{\mathrm{cd}}$ & $19.1^{\mathrm{b}}$ & $27.9^{\mathrm{a}}$ & $53.5^{\mathrm{a}}$ & $35.3^{\mathrm{a}}$ & $0.58^{\mathrm{a}}$ & $0.12^{\mathrm{a}}$ & $1.85^{\mathrm{a}}$ \\
\hline $\mathrm{B}$ & $17.4^{\mathrm{a}}$ & $6.8^{\mathrm{a}}$ & $26.2^{\mathrm{ab}}$ & $14.6^{\mathrm{c}}$ & $38.2^{\mathrm{cd}}$ & $19.5^{\mathrm{d}}$ & $0.73^{\mathrm{c}}$ & $0.36^{\mathrm{b}}$ & $0.74^{\mathrm{c}}$ \\
\hline $\mathrm{C}$ & $13.4^{\mathrm{bc}}$ & $3.8^{\mathrm{bc}}$ & $26.7^{\mathrm{a}}$ & $19.2^{\mathrm{bc}}$ & $45.3^{\mathrm{b}}$ & $26.4^{\mathrm{b}}$ & $0.63^{\mathrm{ab}}$ & $0.34^{\mathrm{bc}}$ & $0.53^{\mathrm{c}}$ \\
\hline $\mathrm{D}$ & $15.3^{\mathrm{ab}}$ & $2.4^{\mathrm{d}}$ & $30.8^{\mathrm{a}}$ & $22.2^{\mathrm{ab}}$ & $41.1^{\mathrm{bc}}$ & $24.2^{\mathrm{bc}}$ & $0.61^{\mathrm{a}}$ & $0.16^{\mathrm{a}}$ & $1.02^{\mathrm{bc}}$ \\
\hline $\mathrm{E}$ & $13.0^{\mathrm{bc}}$ & $4.4^{\mathrm{b}}$ & $32.2^{\mathrm{a}}$ & $18.2^{\mathrm{bc}}$ & $41.1^{\mathrm{bc}}$ & $20.8^{\mathrm{cd}}$ & $0.62^{\mathrm{ab}}$ & $0.27^{\mathrm{c}}$ & $1.54^{\mathrm{ab}}$ \\
\hline $\mathrm{F}$ & $15.3^{\mathrm{ab}}$ & $5.9^{\mathrm{a}}$ & $33.0^{\mathrm{a}}$ & $16.5^{\mathrm{bc}}$ & $33.6^{\mathrm{d}}$ & $22.1^{\mathrm{bcd}}$ & $0.67^{\mathrm{b}}$ & $0.33^{\mathrm{bc}}$ & $0.48^{\mathrm{c}}$ \\
\hline SEM & 0.41 & 0.29 & 1.07 & 0.94 & 1.20 & 1.05 & 0.01 & 0.02 & 0.11 \\
\hline
\end{tabular}

${ }^{1} \mathrm{CP}$, crude protein; EE, ether extract; NFC, non-fibre carbohydrate; $\mathrm{CF}$, crude fibre; NDF, neutral detergent fibre; ADF, acid detergent fibre; SEM, standard error of mean; TDN, total digestible nutrients; $\mathrm{Na}$, sodium; F/C, forage to concentrate ratio.

${ }^{\text {abcd }}$ Values within a column that do not have a common superscript differ significantly $(P<0.05)$ for cows at 70 days or 130 days in milk. 
Table 3. Nutrient intake $(\mathrm{kg} / \mathrm{d})$ provided to cows at 70 and 130 days in milk at six Thai farms

\begin{tabular}{cccccccc}
\hline Farm & DMI $^{\mathrm{l}}$ & CP & EE & NFC & NDF & TDN & Na (g/d) \\
\hline 70 days in milk & & & & & & & \\
A & $13.6^{\mathrm{ab}}$ & $1.44^{\mathrm{a}}$ & $0.40^{\mathrm{a}}$ & $2.29^{\mathrm{a}}$ & $7.63^{\mathrm{b}}$ & $7.59^{\mathrm{ab}}$ & $14.7^{\mathrm{a}}$ \\
B & $11.1^{\mathrm{a}}$ & $2.09^{\mathrm{b}}$ & $0.81^{\mathrm{c}}$ & $2.96^{\mathrm{ab}}$ & $4.11^{\mathrm{a}}$ & $7.90^{\mathrm{ab}}$ & $44.2^{\mathrm{b}}$ \\
C & $11.4^{\mathrm{a}}$ & $1.54^{\mathrm{a}}$ & $0.44^{\mathrm{ab}}$ & $3.29^{\mathrm{bc}}$ & $5.12^{\mathrm{a}}$ & $7.22^{\mathrm{a}}$ & $39.3^{\mathrm{b}}$ \\
D & $12.0^{\mathrm{ab}}$ & $1.93^{\mathrm{ab}}$ & $0.30^{\mathrm{a}}$ & $4.04^{\mathrm{cd}}$ & $4.56^{\mathrm{a}}$ & $8.25^{\mathrm{ab}}$ & $21.2^{\mathrm{a}}$ \\
E & $12.9^{\mathrm{ab}}$ & $1.68^{\mathrm{ab}}$ & $0.57^{\mathrm{b}}$ & $4.45^{\mathrm{d}}$ & $5.21^{\mathrm{a}}$ & $9.09^{\mathrm{ab}}$ & $35.2^{\mathrm{b}}$ \\
F & $14.5^{\mathrm{b}}$ & $3.81^{\mathrm{c}}$ & $0.30^{\mathrm{a}}$ & $3.99^{\mathrm{cd}}$ & $4.46^{\mathrm{a}}$ & $9.63^{\mathrm{b}}$ & $38.0^{\mathrm{b}}$ \\
SEM & 0.33 & 0.13 & 0.04 & 0.15 & 0.23 & 0.23 & 2.11 \\
130 days in milk & & & & & & \\
A & $15.5^{\mathrm{bc}}$ & $1.83^{\mathrm{ab}}$ & $0.49^{\mathrm{a}}$ & $2.96^{\mathrm{a}}$ & $8.32^{\mathrm{b}}$ & $9.07^{\mathrm{a}}$ & $18.4^{\mathrm{a}}$ \\
B & $12.7^{\mathrm{ab}}$ & $2.27^{\mathrm{bc}}$ & $0.89^{\mathrm{b}}$ & $3.41^{\mathrm{ab}}$ & $4.68^{\mathrm{a}}$ & $9.22^{\mathrm{ab}}$ & $47.4^{\mathrm{cd}}$ \\
C & $11.3^{\mathrm{a}}$ & $1.51^{\mathrm{a}}$ & $0.43^{\mathrm{a}}$ & $2.99^{\mathrm{a}}$ & $5.13^{\mathrm{a}}$ & $7.13^{\mathrm{a}}$ & $38.4^{\mathrm{bcd}}$ \\
D & $13.8^{\mathrm{ab}}$ & $2.08^{\mathrm{abc}}$ & $0.32^{\mathrm{a}}$ & $4.21^{\mathrm{ab}}$ & $5.66^{\mathrm{a}}$ & $8.37^{\mathrm{a}}$ & $22.0^{\mathrm{ab}}$ \\
E & $13.5^{\mathrm{ab}}$ & $1.74^{\mathrm{ab}}$ & $0.59^{\mathrm{a}}$ & $4.33^{\mathrm{bc}}$ & $5.53^{\mathrm{a}}$ & $8.32^{\mathrm{a}}$ & $35.7^{\mathrm{abc}}$ \\
F & $17.2^{\mathrm{c}}$ & $2.64^{\mathrm{c}}$ & $1.02^{\mathrm{b}}$ & $5.66^{\mathrm{c}}$ & $5.78^{\mathrm{a}}$ & $11.47^{\mathrm{b}}$ & $56.6^{\mathrm{d}}$ \\
SEM & 0.44 & 0.09 & 0.05 & 0.20 & 0.24 & 0.31 & 2.85 \\
\hline
\end{tabular}

${ }^{\mathrm{l}}$ DMI, dry matter intake; CP, crude protein; EE, ether extract; NFC, non-fibre carbohydrate; NDF, neutral detergent fibre; SEM, standard error of mean; TDN, total digestible nutrients; Na, sodium.

${ }^{\text {abcd }}$ Values within a column that do not have a common superscript differ significantly $(P<0.05)$ for cows at 70 days or 130 days in milk.

\section{At 130 days in milk}

Cows on farm A were fed rations with similar dietary CP contents (Table 2) as the rations used on farms $\mathrm{C}$ and $\mathrm{E}$. The $\mathrm{CP}$ content of the ration was highest on farm B. However, total $\mathrm{CP}$ intake (Table 3) by the cows was highest on farm F due to significantly higher DM intakes. Cows on farm $\mathrm{C}$ had similar CP intakes as the cows on farms $\mathrm{A}, \mathrm{D}$ and $\mathrm{E}$. The cows on farms $\mathrm{B}$ and $\mathrm{F}$ had the highest $\mathrm{EE}$ intakes, which was in line with the significantly higher EE contents of the ration on these farms. The NFC contents of the ration offered to the cows on farms C, D, E and F were similar and significantly higher than the dietary NFC content of the ration fed on farm A. However, the highest intake of NFC was observed at farm F. The intake of NFC by the cows on farms A, B, C and D were similar. Both, the dietary NDF contents and the NDF intakes of the cows that were 130 days in milk followed the same trend as described for the early lactating cows and are in line with the calculated forage to concentrate ratios of the ration. The highest dietary TDN values were calculated for the ration 
fed on farm $\mathrm{F}$ while the ration with the lowest TDN value was fed on farm A and D. With respect to the dietary $\mathrm{Na}$ content, these were similar at both at 70 and 130 days in milk.

Table 4. Mean milk yield (MY), $4 \%$ fat corrected milk (FCM) and milk composition of cows at 70 and 130 days in milk for six Thai farms

\begin{tabular}{|c|c|c|c|c|c|c|c|}
\hline \multirow[t]{2}{*}{ Farm } & \multirow[t]{2}{*}{ No cows } & \multirow[t]{2}{*}{ MY (kg/d) } & \multirow[t]{2}{*}{$\mathrm{FCM}(\mathrm{kg} / \mathrm{d})$} & \multicolumn{4}{|c|}{ Milk composition $(\%)$} \\
\hline & & & & Fat & Protein & Lactose & Non-fat solids \\
\hline \multicolumn{8}{|c|}{70 days in milk } \\
\hline A & 5 & $9.1^{\mathrm{a}}$ & $9.28^{\mathrm{a}}$ & $4.20^{\mathrm{ab}}$ & 2.75 & 4.84 & 8.43 \\
\hline B & 7 & $17.3^{\mathrm{b}}$ & $18.7^{\mathrm{bc}}$ & $4.59^{\mathrm{ab}}$ & 2.97 & 4.87 & 8.64 \\
\hline $\mathrm{C}$ & 5 & $16.9^{\mathrm{b}}$ & $17.8^{\mathrm{bc}}$ & $4.33^{\mathrm{ab}}$ & 3.04 & 4.74 & 8.45 \\
\hline $\mathrm{D}$ & 7 & $17.2^{\mathrm{b}}$ & $16.0^{\mathrm{ab}}$ & $4.16^{\mathrm{ab}}$ & 2.99 & 4.71 & 8.80 \\
\hline $\mathrm{E}$ & 5 & $18.7^{\mathrm{b}}$ & $17.9^{\mathrm{bc}}$ & $3.73^{\mathrm{b}}$ & 2.76 & 5.03 & 8.66 \\
\hline $\mathrm{F}$ & 4 & $23.0^{\mathrm{b}}$ & $25.0^{\mathrm{c}}$ & $4.61^{\mathrm{a}}$ & 2.98 & 4.96 & 8.76 \\
\hline SEM $^{1}$ & & 0.88 & 1.17 & 0.16 & 0.06 & 0.04 & 0.08 \\
\hline \multicolumn{8}{|c|}{130 days in milk } \\
\hline A & 5 & $8.2^{\mathrm{b}}$ & $7.8^{\mathrm{b}}$ & 3.76 & 2.87 & 4.65 & 8.33 \\
\hline B & 5 & $17.2^{\mathrm{a}}$ & $15.6^{\mathrm{a}}$ & 3.81 & 3.23 & 4.83 & 8.88 \\
\hline $\mathrm{C}$ & 5 & $17.8^{\mathrm{a}}$ & $17.8^{\mathrm{a}}$ & 4.02 & 2.85 & 4.85 & 8.54 \\
\hline $\mathrm{D}$ & 5 & $13.7^{\mathrm{ab}}$ & $13.0^{\mathrm{ab}}$ & 4.02 & 3.20 & 4.82 & 8.84 \\
\hline $\mathrm{E}$ & 6 & $17.7^{\mathrm{a}}$ & $18.0^{\mathrm{a}}$ & 4.11 & 3.02 & 4.93 & 8.67 \\
\hline $\mathrm{F}$ & 4 & $13.6^{\mathrm{ab}}$ & $11.7^{\mathrm{ab}}$ & 3.06 & 2.74 & 4.87 & 8.45 \\
\hline SEM & & 0.99 & 0.91 & 0.18 & 0.06 & 0.05 & 0.07 \\
\hline
\end{tabular}

${ }^{1}$ SEM, standard error of mean.

${ }^{\text {abc }}$ Values within a column that do not have a common superscript differ significantly $(P<0.05)$ for cows at 70 days or 130 days in milk.

\section{Milk yield and milk composition}

Milk yield was significantly lower at farm A as compared to farms B, C, D, E and F (Table 4) for 70 days in milk. In terms of fat corrected milk (FCM), milk yield was significantly higher at farm F. Milk fat content was significantly higher on farm F compared to farm E. The contents in milk protein, lactose and non-fat solids were not significantly different among the farms.

At 130 days in milk, the lowest milk yield was observed at farm A which was significantly different from the milk yields recorded at farms B, C and E. Trends of FCM 
were similar to that of milk yield. The concentrations of fat, lactose, protein and non-fat solids in milk were not significantly different between the farms.

\section{Body weight and body condition score}

There were no significant differences in both body weight (BW) and body condition scores (BCS) of cows between farms. Moreover, BW and BCS were not significantly different between 70 and 130 days after calving. Mean BW at 70 and 130 days after calving were 470 $\mathrm{kg}$ (SD 70) and $480 \mathrm{~kg}$ (SD 70), respectively. Mean BCS were 2.90 (SD 0.35) and 2.80 (SD $0.35)$ at 70 and 130 days after calving, respectively.

Table 5. Correlations between nutrient intake $(\mathrm{kg} / \mathrm{d})$ and milk yield $(\mathrm{MY}, \mathrm{kg} / \mathrm{d})$ for cows 70 and 130 days in milk at six Thai farms

\begin{tabular}{lcccc}
\hline Component & \multicolumn{2}{c}{70 days in milk } & \multicolumn{2}{c}{130 days in milk } \\
\cline { 2 - 5 } & $n$ & MY & 30 & MY \\
\hline CP $^{\mathrm{a}}$ & 33 & $\mathbf{0 . 6 5}$ & 30 & 0.22 \\
$\mathrm{EE}$ & 33 & 0.17 & 30 & 0.31 \\
$\mathrm{NFC}$ & 33 & $\mathbf{0 . 6 7}$ & 30 & 0.24 \\
$\mathrm{NDF}$ & 33 & $\mathbf{- 0 . 4 3}$ & 30 & $\mathbf{- 0 . 4 2}$ \\
$\mathrm{TDN}$ & 33 & $\mathbf{0 . 5 9}$ & 30 & 0.09 \\
$\mathrm{Na}(\mathrm{g} / \mathrm{d})$ & 33 & $\mathbf{0 . 6 2}$ & $\mathbf{0 . 5 5}$ \\
\hline
\end{tabular}

${ }^{\mathrm{a}} \mathrm{CP}$, crude protein; EE, ether extract; NFC, non-fibre carbohydrate; NDF, neutral detergent fibre; TDN, total digestible nutrients; $\mathrm{Na}$, sodium.

Values in bold indicate significant $(P<0.05)$ correlations.

\section{Correlations between milk yield and ration}

The correlations between milk and nutrient intake are presented in Table 5. Milk yield was positively correlated with dietary CP, NFC, TDN and Na intake and negatively correlated with NDF intake $(P<0.05)$ at 70 DIM, while milk yield was positively correlated with Na intake and negatively correlated with NDF intake $(P<0.05)$ only in the mid lactating cows. 


\section{DISCUSSION}

Among the farms investigated during early lactation (70 DIM), A had the lowest milk production, whereas the highest milk production was found for F. Although DMI was not different between these two farms, the intake of nutrients such as protein, NFC, TDN and Na was low on farm A, probably because of the high forage to concentrate ratio in the ration as indicated by the high intake of NDF of the cows on farm A. It is generally accepted that milk yield is positively correlated with concentrate intake and negatively with forage intake (McEvoy et al., 2008; Tessmann et al., 1991; Friggens et al., 1998; Murphy et al., 2000). Indeed, the dietary forage to concentrate ratio was numerically lowest on farm $\mathrm{F}$. Concentrates have a high CP and TDN content whereas the forage in tropical countries are high in NDF and low in both CP and TDN. Therefore, cows which are fed high amounts of concentrate will receive more protein and TDN which affects milk production. In contrast to the data obtained at 70 days after calving, milk production of the cows at 130 days was similar on farms A and F. However, the significantly lower protein intake $(P<0.02)$ of the cows on farm $\mathrm{F}$ at 130 versus 70 days after calving might explain this apparent discrepancy as both energy and protein intake are related to milk production. These results are supported by previous reports showing that milk production increases in response to increased protein intake over a range of energy intakes (Frank and Swensson, 2002; Macleod et al., 1984; Tessmann et al., 1991).

\section{Efficiency of milk production}

Across herds and the two stages of lactation, the average efficiency of the conversion of feed into milk (kg FCM/kg DMI) was calculated to be 1.22. This value is lower than that can be calculated on the basis of data reported by Blake et al. (1986); i.e. 1.40. In the latter study, Holstein cows with mean BW of $537 \mathrm{~kg}$ were used and data were obtained at 75 and 143 DIM (Blake et al., 1986). Therefore, it can be speculated the difference in feed efficiency (i.e. 1.22 versus $1.40 \mathrm{~kg} \mathrm{FCM} / \mathrm{kg}$ DMI) is caused by the nutrient composition of the rations. This notion is corroborated by the current observation that, at least at 70 DIM, the feed efficiency on farm F was greater than that on farm A (i.e. 0.50 and 1.72, respectively) and that the nutrient density (g/kg DM) of the ration on farm F versus farm A also was greater (Table 2).

During mid lactation, cows on farm $\mathrm{C}$ and $\mathrm{E}$ had a higher feed efficiency than cows on farms A and F (Figure 1). The percentage of NFC on farm E was high which is associated with a high concentrate intake, but the cows on farm $\mathrm{E}$ had a high $\mathrm{F} / \mathrm{C}$ in combination with a 
high \%NFC. However, the higher F/C and lower protein intake on farm E did not cause the low milk production. This might indicate that the cows on farm E were fed with high quality roughage such as corncobs and legume (Centrosema pascuorum cv. Cavalcade). The relatively high $\% \mathrm{NDF}$ on farm $\mathrm{E}$ might be associated with a higher quality of forage which leads to a better utilization of NDF which may have stimulated the fermentation activity, resulting in an increased DMI, leading to higher milk production (Grant, 1997).
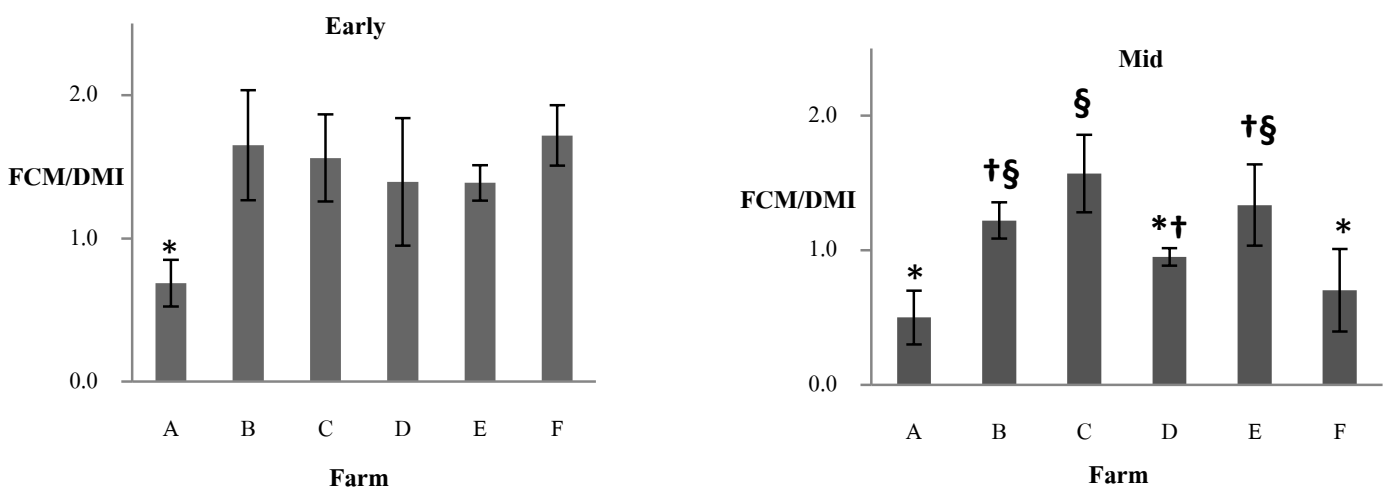

Figure 1. Average and standard deviation of feed efficiency of dairy cows in early and mid lactation on six farms (A-F) in Thailand. ${ }^{*}, \uparrow, \S$ different symbols indicate significant differences $(P<0.05)$ between bars. FCM, $4 \%$ fat corrected milk; DMI, dry matter intake.

\section{Composition of milk}

Over a wide range of nutrient intakes (Table 3), the contents of protein, lactose and non-fat solids in milk were found to be similar between farms. This observation is in line with the well accepted idea that the contents of protein, lactose and ash in milk are not very sensitive to changes in ration composition (Linn, 1988). In contrast, the fat content of milk showed more variation between farms and at 70 compared to 130 DIM and found to be different between farms $\mathrm{E}$ and $\mathrm{F}$. A major dietary characteristic that influences the fat content of milk is $\mathrm{F} / \mathrm{C}$, at least in rations with low fat contents (7-8\% DM) (Palmquist and Conrad, 1978), and a high F/C is generally associated with a high fat content of milk (Linn, 1988). However, F/C of the rations fed at farm $\mathrm{F}$ was lower than that of farm $\mathrm{E}$ while the cows had farm $\mathrm{F}$ had higher milk fat contents. Clearly, $\mathrm{F} / \mathrm{C}$ ratio does not explain the difference in milk fat content between the two farms. Next to the dietary F/C, the amount and degradation rate of NFC is of interest with respect to the milk fat content and both a high NFC intake and rapid degradation rate of NFC are associated with lower contents of milk fat (Batajoo and Shaver, 1994). Thus, it may be speculated that the lower milk fat contents found on farm $\mathrm{E}$ are related, at least partially, to a difference in NFC intake. Indeed, NFC intake by the cows on farm E was $11.5 \%$ 
greater than on farm F. It thus appears that the concentrates fed to the cows on farm $\mathrm{E}$ had a high content of NFC because $\mathrm{F} / \mathrm{C}$ of the ration on farm $\mathrm{E}$ was higher than at farm F; i.e. 1.43 and 0.47 , respectively. Unfortunately, the ingredient composition of the commercial concentrate fed at farm E is not known but perhaps the NFC had a rapid degradation rate. Finally, the cows at farm $\mathrm{F}$ produced $23 \%$ more milk than the cows at farm $\mathrm{E}$ and it can therefore not be excluded that the cows at farm $\mathrm{F}$ versus $\mathrm{E}$, experienced a greater nadir negative energy balance (NEB). This condition also can potentially attribute to the difference in milk fat content between farm $\mathrm{E}$ and $\mathrm{F}$ because fatty acids mobilized during NEB are partially excreted with milk (Stoop et al., 2009).

\section{Correlation between milk and nutrient intake}

The correlation between TDN and NFC intake and milk yield was 0.59 and 0.67 , respectively, in early lactation while this correlation was not evident in mid lactation. The current observation is corroborated by Coulon and Remond (1991), who reported that milk yield response to energy supply was greater for cows in early than mid lactation. In practice, TDN is used as a measure of energy to formulate rations of Thai dairy cows. However, energy requirements are expressed as $\mathrm{MJ} \mathrm{NE}_{\mathrm{L}}$ by the NRC (2001). Therefore, current TDN values were converted into $\mathrm{NE}_{\mathrm{L}}$ using the equation: $\mathrm{NE}_{\mathrm{L}}=0.0245 \times \mathrm{TDN}-0.12(\mathrm{NRC}, 2001)$. It appeared that $\mathrm{NE}_{\mathrm{L}}$ intake during early lactation was $5 \%$ lower than required while $\mathrm{NE}_{\mathrm{L}}$ intake was $14 \%$ greater than required during mid lactation. Thus, it can be suggested that the intake of extra energy does not increase milk production in mid lactation. Therefore, in terms of milk production, it is not advantageous to provide more energy than NRC requirements to cows in mid lactation.

The positive correlation $(\mathrm{r}=0.65)$ between milk yield and $\mathrm{CP}$ intake was clearly high during early lactation. Both during early and mid-lactation, cows consumed greater amounts of CP than recommended by the NRC (2001). The extra intake of CP was approximately 5 and $8 \%$, respectively. It may be suggested that early lactating cows in Thailand fed locally available roughages require somewhat more $\mathrm{CP}$ than indicated by the NRC. Interestingly, significant positive correlations were calculated between $\mathrm{Na}$ intake and milk yield. This observations is somewhat difficult to explain because $\mathrm{Na}$ intake was highly correlated with concentrate intake $(r=0.66)$. In other words, the increase milk yield may be related to a higher intake of $\mathrm{Na}$ but this is confounded with the amount of concentrate intake. On the other hand, the temperature humidity index (THI) ranged from 71 to 83 (Table 1) indicating that the cows experienced mild to moderate heat stress (Armstrong, 1994) during the current study. 
Sanchez et al. (1994) have suggested that the Na requirement is increased during heat stress due to the higher $\mathrm{Na}$ loss associated with sweating. Moreover, the current observation is line with results reported by Schneider et al. $(1984,1986)$ who suggested that the feeding of $\mathrm{Na}$ above the current NRC recommendations (i.e. 1.9-2.2 $\mathrm{g} / \mathrm{kg} \mathrm{DM}$ ) may stimulate milk production in heat stressed cows.

In conclusion, protein, non-fibre carbohydrates and $\mathrm{Na}$ intake may have limited milk production by dairy cows on the Thai farms participating in the current study.

\section{ACKNOWLEDGMENTS}

The authors would like to thank all dairy farms for their contribution to this study. Financial support was provided by the Faculty of Veterinary Medicine, Kasetsart University.

\section{REFERENCES}

Armstrong, D. V. 1994. Heat stress interaction with shade and cooling. J. Dairy Sci. 77:20442050.

Association of Official Analytical Chemists (AOAC). 1990. Official Methods of Analysis. Washington, DC.

Balch, C. C. 1976. The potential of poor-quality agriculture roughages for animal feeding, in New Feed Resources, Proceedings of a Technical Consultation, FAO Animal Production and Health Paper, Rome, Italy.

Blake, R. W., A. A. Custodio and W. H. Howard. 1986. Comparative feed efficiency of Holstein and Jersey cows. J. Dairy. Sci. 69:1302-1308.

Batajoo, K. K. and R. D. Shaver. 1994. Impact of nonfiber carbohydrate on intake, digestion, and milk production by dairy cows. J. Dairy Sci. 77:1580-1588.

Coulon, J. B. and B. Remond. 1991. Variations in milk output and milk protein content in response to the level of energy supply to the dairy cow: a review. Livest. Prod. Sci. 29:31-47.

Department of Livestock Development (DLD). 2011. Data of the number of farmer and dairy cows, in The Number of Livestock in Thailand. Information and statistics group, Department of Livestock Development, Bangkok, pp. 27-42 (in Thai).

Edmonson, A. J., I. J. Lean, L. D. Weaver, T. Farver and G. Webster. 1989. A body condition scoring chart for Holstein dairy cows. J. Dairy Sci. 72:68-78. 
Frank, B. and C. Swensson. 2002. Relationship between content of crude protein in rations for dairy cows and milk yield, concentration of urea in milk and ammonia emissions. J. Dairy Sci. 85:1829-1838.

Friggens, N. C., G. C. Emmans, I. Kyriazakis, J. D. Oldham and M. Lewis. 1998. Feed intake relative to stage of lactation for dairy cows consuming total mixed diets with a high or low ratio of concentrate to forage. J. Dairy Sci. 81:2228-2239.

Grant, R. J. 1997. Interactions among forages and non forage fiber sources. J. Dairy Sci. 80:1438-1446.

Heinrichs, A. J., G. W. Rogers and J. B. Cooper. 1992. Predicting body weight and wither height in Holstein heifers using body measurements. J. Dairy Sci. 75:3576-3581.

Kanjanapruthipong, J. 2006. Dairy Herd Management. Kasetsart University Press, Thailand, p. 230 (in Thai).

Leng, R. A. 1995. Appropriate technologies for field investigations in ruminant livestock nutrition in developing countries, in Agricultural Sciences for Biodiversity and Sustainability in Developing Countries, Proceedings of a Workshop, Tune Landbskole, Denmark, pp. 57-77.

Linn, J. G. 1988. Factors affecting the composition of milk from dairy cows, in Designing Foods: Animal Product Options in the Marketplace. National Academy Press, Washington, DC, USA, pp. 224-241.

Macleod, G. K., D. G. Grieve, I. McMillan and G. C. Smith. 1984. Effect of varying protein and energy densities in complete rations fed to cows in first lactation. J. Dairy Sci. 67:1421-1429.

McEvoy, M., E. Kennedy, J. P. Murphy, T. M. Boland, L. Delaby and M. O'Donovan. 2008. The effect of herbage allowance and concentrate supplementation on milk production performance and dry matter intake of spring-calving dairy cows in early lactation. $\mathrm{J}$. Dairy Sci. 91:1258-1269.

Murphy, M., M. Akerlind and K. Holtenius. 2000. Rumen fermentation in lactating cows selected for milk fat content fed two forage to concentrate ratios with hay or silage. J. Dairy Sci. 83:756-764.

National Research Council (NRC). 2001. Nutrient Requirements of Dairy Cattle (7th rev. edn). National Academy Press, Washington, DC.

Palmquist, D. L. and H. R. Conrad. 1978. High fat rations for dairy cows. Effects on feed intake, milk and fat production, and plasma metabolites. J. Dairy Sci. 61:890-901. 
Rhoads, M. L., R. P. Rhoads, M. J. VanBaale, R. J. Collier, S. R. Sanders, W. J. Weber, B. A. Crooker and L. H. Baumgard. 2009. Effects of heat stress and plane of nutrition on lactating Holstein cows: I. Production, metabolism, and aspects of circulating somatotropin. J. Dairy Sci. 92:1986-1997.

Sanchez, W. K., M. A. McGuire and D. K. Beede. 1994. Macromineral nutrition by heat stress interactions in dairy cattle: review and original research. J. Dairy Sci. 77:20512079.

Schneider, P. L., D. K. Beede and C. J. Wilcox. 1986. Responses of lactating cows to dietary sodium source and quantity and potassium quantity during heat stress. J. Dairy Sci. 69:99-110.

Schneider, P. L., D. K. Beede, C. J. Wilcox and R. J. Collier. 1984. Influence of dietary sodium and potassium bicarbonate and total potassium on heat-stressed lactating dairy cows. J. Dairy Sci. 67:2546-2553.

Stoop, W. H., H. Bovenhuis, J. M. L. Heck and J. A. M. van Arendonk. 2009. Effect of lactation stage and energy status on milk fat composition of Holstein-Friesian cows. J. Dairy Sci. 92:1469-1478.

Tessmann, N. J., H. D. Radloff, J. Kleinmans, T. R. Dhiman and L. D. Satter. 1991. Milk production response to dietary forage:grain ratio. J. Dairy Sci. 74:2696-2707.

Tumwasorn, S., K. Markvichitr and P. Duangpatra. 1997. Effects of breeds and level of management on milk yield, body condition, and artificial insemination index in dairy cattle, in The 35th Kasetsart University Annual Conference, Bangkok, Thailand, pp: 128-135.

Van Soest, P. J., J. B. Robertson and B. A. Lewis. 1991. Methods for dietary fiber, neutral detergent fiber, and non starch polysaccharides in relation to animal nutrition. J. Dairy Sci. 74:3583-3597. 


\section{Chapter 3}

\section{An Attempt to Define the Sodium Requirement of Lactating Dairy Cows in a Tropical Environment}

Wandee Thiangtum $^{1,2}$, Adisorn Yawongsa ${ }^{1,2}$, J Thomas Schonewille ${ }^{2}$, Theera Rukkwamsuk ${ }^{1}$, Chalermpon Yuangklang ${ }^{3}$, Martin WA Verstegen ${ }^{2}$ and Wouter H Hendriks ${ }^{2,4}$

\footnotetext{
${ }^{I}$ Department of Large Animal and Wildife Clinical Sciences, Faculty of Veterinary Medicine, Kasetsart University, Thailand

${ }^{2}$ Department of Farm Animal Health, Faculty of Veterinary Medicine, University, Utrecht, The Netherlands

${ }^{3}$ Department of Animal Science, Faculty of Natural Resources, Rajamangala University of Technology Isan, Thailand

${ }^{4}$ Department of Animal Sciences, Wageningen University, Wageningen, The Netherlands
}

Journal of the Science of Food and Agriculture (2011) 91:2333-2337 


\begin{abstract}
Lactating dairy cattle in the tropics may require more $\mathrm{Na}$ due to the hot and humid climatic conditions. It is unknown whether the current recommendations of $\mathrm{Na}$ for lactating cows can be quantitatively used in the tropical countries. This study attempted to define the sodium requirement of lactating dairy cows under tropical conditions by measuring $\mathrm{Na}$ in saliva, milk and faeces. The concentrations of $\mathrm{Na}$ and $\mathrm{K}$ in milk, faeces and serum were not affected by dietary treatments. The amount of $\mathrm{Na}$ absorbed by cows fed the basal diet containing $0.4 \mathrm{~g}$ $\mathrm{Na} / \mathrm{kg} \mathrm{DM}$ was equal to the amount of $\mathrm{Na}$ lost in the milk, showing that these animals were fed an Na-deficient ration. This observation was corroborated by the salivary $\mathrm{Na}$ and $\mathrm{K}$ levels, with the cows on the low-Na diet having salivary $\mathrm{Na}$ concentrations below $120 \mathrm{mmol} / \mathrm{L}$ in combination with salivary $\mathrm{K}$ concentrations above $20 \mathrm{mmol} / \mathrm{L}(P<0.05)$. Consumption of a daily ration formulated to contain the current $\mathrm{Na}$ requirement set by the NRC appears to provide too much $\mathrm{Na}$ for lactating cows under tropical conditions. A tentative value of $1.2 \mathrm{~g}$ $\mathrm{Na} / \mathrm{kg} \mathrm{DM}$ is proposed as the Na requirement for dairy cows under tropical conditions.
\end{abstract}




\section{INTRODUCTION}

Sodium $(\mathrm{Na})$ is a primary extracellular cation in animals and its main functions include maintenance of body fluid balance, osmotic pressure, and acid-base balance (McKenown, 1986). Furthermore, $\mathrm{Na}$ is a major component of minerals present in saliva and it buffers acids produced during ruminal fermentation (Blair-West et al., 1970). In cows, Na deficiency has been associated with loss of appetite, decreased milk yield and pica (NRC, 2001). In ruminants the salivary $\mathrm{Na}$ concentrations drops to levels below $120 \mathrm{mmol} / \mathrm{L}$ with a concomitant increase in salivary $\mathrm{K}$ concentration during Na deficiency (Schonewille and Beynen, 2005a). Therefore an assessment of salivary $\mathrm{Na}$ and $\mathrm{K}$ concentration is highly instrumental in diagnosing $\mathrm{Na}$ deficiency. Clearly, a drop in the salivary $\mathrm{Na}$ concentration in combination with an increased level of salivary $\mathrm{K}$ results in a decreased $\mathrm{Na} / \mathrm{K}$ ratio. Indeed, it was suggested by Schonewille and Beynen (2005a) that a salivary Na/K ratio lower than 6 is indicative of $\mathrm{Na}$ deficiency. The current $\mathrm{Na}$ requirements for dairy cows recommended by various authorities range from 0.5 to $2.2 \mathrm{~g} / \mathrm{kg}$ DM (Table 1). However, it is unclear whether these recommendations can be quantitatively extrapolated to tropical conditions, because all requirements were set under temperate conditions. Consequently, the Na requirements listed in Table 1 do not specifically take into account $\mathrm{Na}$ loss through sweating during heat stress. Indeed, it was suggested by Sanchez et al. (1994) that the Na requirement is increased during heat stress owing to the higher Na loss associated with sweating. Furthermore, Schneider $e t$ al. $(1986,1984)$ reported that dry matter intake (DMI) was increased during heat stress when the dietary $\mathrm{Na}$ content was increased from 1.8 to $5.5 \mathrm{~g} / \mathrm{kg}$ diet. This increase in DMI can be explained by the possibility that animals fed the low-Na ration were in negative Na balance.

In tropical countries such as Thailand the level of $\mathrm{Na}$ in feedstuffs used to formulate dairy rations is much lower than recommend (Minson, 1990) by the various authorities (Table 1) and therefore dairy rations are routinely supplemented with $\mathrm{Na}$. The scientific basis for the amounts of $\mathrm{Na}$ addition to the ration, however, is scant. Generally, dairy cattle in tropical countries have lower production and consume poorer-quality feeds while exposed, at certain times to high temperature and relative humidity. In addition, excessive $\mathrm{Na}$ intake relative to the animals' requirement should be avoided in tropical countries in the light of responsible water management and water scarcity, as water consumption increases to excessive Na intake to maintain normal physiological $\mathrm{Na}$ concentrations in the extracellular fluid. The aim of this study was to attempt to define the $\mathrm{Na}$ requirement of lactating dairy cows under tropical conditions by measuring $\mathrm{Na}$ level in saliva, milk and faeces. 
Table 1. Summary of sodium $(\mathrm{Na})$ requirements set by different authorities

\begin{tabular}{lc}
\hline Reference & Na requirement $(\mathrm{g} / \mathrm{kg} \mathrm{DM})$ \\
\hline Underwood and Suttle, 1999 & $0.5-1.0$ \\
ARC, 1980 & $0.8-1.2$ \\
CVB, 2005 & $0.7^{\mathrm{a}}-1.4^{\mathrm{b}}$ \\
DLG, 2001 & $1.0-1.5^{\mathrm{b}}$ \\
INRA, 1989 & $1.0-1.7$ \\
NRC, 2001 & $1.9-2.2$ \\
\hline
\end{tabular}

${ }^{\mathrm{a}}$ Dry cows.

${ }^{\mathrm{b}}$ Lactating cow, $40 \mathrm{~kg}$ of milk.

\section{MATERIALS AND METHODS}

\section{Animals and experimental design}

Fifteen crossbred multiparous Holstein Friesian (HF $\times$ indigenous) cows with a mean body weight of $485 \mathrm{~kg}$ (standard deviation (SD) $74 \mathrm{~kg}$ ) and 93 days in milk (SD 39 days) were used. The cows were housed individually in a naturally ventilated tied stall for a period of 28 days, whereafter, during the following 9 days, they were housed in individual metabolic cages to facilitate the collection of faeces, saliva and blood. The experiment was conducted during the summer season from March to April with the cows exposed to local climatic conditions. Daily minimum and maximum temperatures directly outside the stall were measured throughout the study. Cows were fed individually and milked twice daily at 06:00 and 17:00. Prior to the start of the experiment, animals were randomly assigned to one of three dietary treatments, i.e. low, medium or high $\mathrm{Na}$.

\section{Experimental rations}

All cows were fed a total mixed ration (TMR). The basal TMR was formulated to be deficient in $\mathrm{Na}$ (Table 2) and contained $0.4 \mathrm{~g} \mathrm{Na} / \mathrm{kg} \mathrm{DM}$. The medium- and high-Na rations were formulated by supplementing the basal ration with two levels of salt $(\mathrm{NaCl})$. The $\mathrm{Na}$ contents of the medium- and high-Na rations were 1.6 and $4.0 \mathrm{~g} / \mathrm{kg} \mathrm{DM}$, respectively. The ingredient and nutrient composition of the three dietary treatments are given in Table 2. The TMR was offered ad libitum twice daily and leftovers were removed twice daily before feeding. Water was available for all cows at all times. 
Table 2. Ingredient and nutrient compositions of the low-, medium- and high-sodium (Na) experimental rations

\begin{tabular}{lccc}
\hline Component & Low Na & Medium Na & High Na \\
\hline Ingredient composition (g/kg as fed) & & & \\
Constant components ${ }^{\mathrm{a}}$ & 630.0 & 630.0 & 630.0 \\
Cassava chips & 370.0 & 367.0 & 361.0 \\
Salt $(\mathrm{NaCl})$ & - & 3.0 & 9.0 \\
Analysed nutrient composition & & & \\
Dry matter, g/kg as fed & 797.2 & 768.6 & 791.7 \\
Crude protein, g/kg & 173.3 & 171.2 & 166.1 \\
Ether extract, g/kg & 47.7 & 45.1 & 46.0 \\
Crude ash g/kg & 90.5 & 86.4 & 91.7 \\
Neutral detergent fibre, g/kg & 376.2 & 385.3 & 352.6 \\
Acid detergent fibre, g/kg & 231.8 & 240.8 & 212.9 \\
Sodium, g/kg & 0.4 & $1.6^{\mathrm{b}}$ & $4.0^{\mathrm{b}}$ \\
Potassium, g/kg & 10.2 & 10.7 & 10.2 \\
\hline
\end{tabular}

${ }^{\mathrm{a}}$ The constant components were $112 \mathrm{~g}$ soybean meal, $50 \mathrm{~g}$ dried tomato pomace, $100 \mathrm{~g}$ cottonseed meal, $51 \mathrm{~g}$ dried brewer's grain, $17 \mathrm{~g}$ tallow, $62 \mathrm{~g}$ molasses, $18 \mathrm{~g}$ urea, $1 \mathrm{~g}$ dicalcium phosphate, 3 $\mathrm{g}$ magnesium oxide, $6 \mathrm{~g}$ oystershell, $2 \mathrm{~g}$ sulphur, $205 \mathrm{~g}$ milled rice straw, $3 \mathrm{~g}$ mineral premix per $\mathrm{kg}$ diet. The mineral premix consisted of 440,000 IU vitamin A, 60,000 IU vitamin $\mathrm{D}_{3}, 30,000 \mathrm{IU}$ vitamin E, 11.6 g Fe, 0.03 g Mn, 5.6 g Cu, $11.60 \mathrm{~g} \mathrm{Zn,} 0.07 \mathrm{~g} \mathrm{I}, 0.06 \mathrm{~g} \mathrm{Se}, 10.0 \mathrm{~g} \mathrm{Mg}$ and $15.0 \mathrm{~g}$ $\mathrm{P}$ per kg.

${ }^{\mathrm{b}}$ Calculated on the basis of the analysed $\mathrm{Na}$ content of the low-Na ration and the amount of $\mathrm{Na}$ supplementation.

\section{Sample collection and chemical analyses}

Feed intake of each cow was recorded daily during the collection period. Samples of the TMR were taken weekly, dried at $60{ }^{\circ} \mathrm{C}$, ground and pooled per treatment before analyses of dry matter, crude protein and crude fibre according to AOAC procedures (AOAC, 1990). Intrinsic $\mathrm{Na}$ and $\mathrm{K}$ of the TMR were measured using wet ashing and atomic absorption spectrophotometry.

Faeces were quantitatively collected and weighed each day during the 5 day collection period. The faeces collected each day were thoroughly mixed and samples of $10 \%$ of the total amount of faeces were taken and stored at $-18{ }^{\circ} \mathrm{C}$ in plastic bags. At the end of the experiment the faeces samples were pooled for each cow and mixed thoroughly. The pooled samples were 
dried at $60{ }^{\circ} \mathrm{C}$, ground and stored until analyses for $\mathrm{Na}$ and $\mathrm{K}$. Data from feed and faeces were used to derive the amount of $\mathrm{Na}$ and $\mathrm{K}$ being absorbed.

Milk production was recorded during the collection period and samples of approximately $30 \mathrm{~mL}$ per milking time (06:00 and 17:00) were collected for 5 days. Milk samples in proportion to yield on the sampling day were preserved by the addition of $0.2 \mathrm{~g} / \mathrm{L}$ 2-Bromo-2-nitro-1, 3-propanediol and stored at $5{ }^{\circ} \mathrm{C}$. Five-day milk samples from each cow were mixed, deproteinised with $100 \mathrm{~g} / \mathrm{L}$ trichloroacetic acid, vortexed and centrifuged at 800 $\times g$ for $10 \mathrm{~min}$, whereafter the supernatant was stored at $-18^{\circ} \mathrm{C}$ until mineral analyses.

Blood samples $(10 \mathrm{~mL})$ were collected from the jugular vein of each cow at the last day of the collection period at 10:00. Serum samples were obtained by centrifuging of the blood samples at $800 \times g$ for $5 \mathrm{~min}$. All serum samples were stored at $-20{ }^{\circ} \mathrm{C}$ until mineral analyses.

Saliva samples were collected on day 4 of the faeces collection period before the morning feeding to prevent $\mathrm{Na}$ contamination by the feed. Saliva sampling was done by placing sponges in the mouths of the cows at the third premolar in the maxilla for a period of 3 min. Subsequently the liquid in the sponges was collected into a plastic bag, transferred into a tube and stored at $-18^{\circ} \mathrm{C}$. Each sponge was washed thoroughly with demineralised water and dried at $40^{\circ} \mathrm{C}$ on a glass plate before being used to collect saliva.

All samples of faeces, milk, serum and saliva were analysed for $\mathrm{Na}$ and $\mathrm{K}$ using a flame emission atomic absorption spectrophotometer (AA-6800, Shimadzu, Kyoto, Japan) in accordance with the manufacturer's specification.

\section{Calculations and statistical analysis}

The data were statistically analysed by subjecting them to analysis of variance with treatment as factor. Multiple comparisons between groups were made by Duncan's test. All the statistical analyses were performed using SPSS for Windows 11.5 (SPSS Inc., Chicago, IL, USA) with the level of significance pre-set at $5 \%$.

\section{RESULTS AND DISCUSSION}

The mean neutral detergent fibre content of experimental rations was found to be $371 \mathrm{~g} / \mathrm{kg}$ (SD 16.9, $n=3$ ), which is lower than recommended by NRC (2001). However, the animals showed normal rumination, were apparently healthy and remained in good condition during the experiment. DMI was not affected by dietary treatment $(P>0.38)$. The mean intake for all cows was $16.5 \mathrm{~kg} / \mathrm{d}$ DM (standard error (SE) 0.33). The observed level of DMI was 
somewhat lower than anticipated, i.e. $16.5 \mathrm{vs} 18 \mathrm{~kg} / \mathrm{d}$. Although there was no significant differences in DMI among treatments, DMI tended to increase with Na supplementation (low, $15.9 \mathrm{~kg} / \mathrm{d}$; medium, $16.3 \mathrm{~kg} / \mathrm{d}$; high, $17.1 \mathrm{~kg} / \mathrm{d}$ ). In a study by Sanchez et al. (1997) dietary supplementation with $\mathrm{NaCl}$ did not alter DMI. In some earlier studies, DMI was increased when cows received a ration with an increased amount of both $\mathrm{Na}$ and $\mathrm{K}$ (Beede, 1991; Silanikove et al., 1998). We only applied our treatment for a period of 37 days, which was not sufficiently long to induce severe Na deprivation in the low-Na fed animals. Aines and Smith (1957) reported that mild to severe symptoms of Na deficiency were shown after 16 months of feeding a low-Na diet, because the rumen could act as a buffer and contain up to $50 \%$ of the available body $\mathrm{Na}$ (Bell, 1995).

As expected, $\mathrm{Na}$ intake was significantly affected by treatment (Table 3). Faeces $\mathrm{Na}$ excretion was significantly higher in the medium- and high-Na groups than in the low-Na group. Apparent $\mathrm{Na}$ absorption expressed as a percentage of intake was significantly higher with the high-Na diet. Apparent $\mathrm{Na}$ absorption ranged between 80 and $96 \%$ of intake, which is in agreement with Kemp (1964) and Martz et al., (1988) who reported a similar range in apparent $\mathrm{Na}$ absorption in dairy cows. The relatively low level of apparent $\mathrm{Na}$ absorption in cows fed the low-Na ration can be explained by the inevitable faecal $\mathrm{Na}$ loss. Based on specific assumptions for estimating the endogenous faecal $\mathrm{Na}$ loss, a value of $1.6 \mathrm{~g} / \mathrm{d}$ was calculated by Schonewille and Beynen (2005a). This value is similar to the faecal Na loss of $1.4 \mathrm{~g} / \mathrm{d}$ in the low-Na fed cows. The cows fed the low-Na diet also had a very low $\mathrm{Na}$ concentration in the saliva (Table 4). Apparent $\mathrm{K}$ absorption was not significantly affected by dietary $\mathrm{Na}$ concentration and was $93 \%$ of intake (Table 3 ). This value is in agreement with the results of Hemken (1983) and Greene et al. (1983a,b) who reported an apparent faecal digestibility of $95 \%$ or higher for most feedstuffs. 
Table 3. Sodium and potassium intake, faecal excretion, apparent absorption and milk content of dairy cows fed low-, medium- and high-sodium $(\mathrm{Na})$ rations

\begin{tabular}{|c|c|c|c|c|c|}
\hline \multirow[t]{2}{*}{ Parameter } & \multicolumn{3}{|c|}{ Treatment } & \multirow[t]{2}{*}{ Pooled SEM } & \multirow[t]{2}{*}{$P$ value } \\
\hline & Low $\mathrm{Na}$ & Medium Na & High $\mathrm{Na}$ & & \\
\hline \multicolumn{6}{|l|}{ Sodium } \\
\hline Intake, $\mathrm{g} / \mathrm{d}$ & $6.9^{\mathrm{a}}$ & $26.3^{\mathrm{b}}$ & $67.8^{\mathrm{c}}$ & 6.8 & $<0.001$ \\
\hline Faeces, g/d & $1.4^{\mathrm{a}}$ & $3.0^{\mathrm{b}}$ & $2.6^{\mathrm{ab}}$ & 0.3 & 0.041 \\
\hline Absorption, g/d & $5.5^{\mathrm{a}}$ & $23.3^{\mathrm{b}}$ & $65.2^{\mathrm{c}}$ & 6.7 & $<0.001$ \\
\hline Absorption, $\%$ of intake & $80.2^{\mathrm{a}}$ & $88.7^{\mathrm{ab}}$ & $96.1^{\mathrm{b}}$ & 2.4 & 0.013 \\
\hline Milk, g/d & 5.5 & 6.5 & 6.9 & 0.4 & 0.446 \\
\hline \multicolumn{6}{|l|}{ Potassium } \\
\hline Intake, $\mathrm{g} / \mathrm{d}$ & 162.7 & 173.8 & 173.7 & 3.4 & 0.328 \\
\hline Faeces, g/d & 12.1 & 11.6 & 12.1 & 0.8 & 0.972 \\
\hline Absorption, g/d & 150.5 & 162.2 & 161.6 & 2.9 & 0.758 \\
\hline Absorption, $\%$ of intake & 92.6 & 93.3 & 93.2 & 0.4 & 0.198 \\
\hline Milk, g/d & 23.6 & 25.4 & 29.3 & 1.7 & 0.422 \\
\hline
\end{tabular}

Concentrations of salivary $\mathrm{Na}$ and $\mathrm{K}$ are given in Table 4. When dietary supply of $\mathrm{Na}$ is sufficient, the salivary $\mathrm{Na}$ concentrations is higher than $120 \mathrm{mmol} / \mathrm{L}$ (Morris et al., 1980). In the present study the cows fed the low-Na ration had a salivary $\mathrm{Na}$ concentration of 95.6 $\mathrm{mmol} / \mathrm{L}$, indicating that these animals were fed below their Na requirement. The salivary $\mathrm{K}$ concentration was approximately $12 \mathrm{mmol} / \mathrm{L}$ after feeding the medium- and high-Na rations. This level is similar to the value set by Silanikove et al. (1998) as a tentative criterion for a sufficient supply of dietary $\mathrm{Na}$. In Na-deficient ruminants, there is a replacement of $\mathrm{Na}^{+}$with $\mathrm{K}^{+}$in the saliva, causing a reduction in the $\mathrm{Na} / \mathrm{K}$ ratio (Murphy and Connell, 1970; Underwood and Suttle, 1999). The use of the salivary $\mathrm{Na} / \mathrm{K}$ ratio as a diagnostic tool to detect $\mathrm{Na}$ deficiency has been extensively reviewed by Schonewille and Beynen (2005a) and Suttle (2010), and it was concluded that an $\mathrm{Na} / \mathrm{K}$ ratio lower than 6 (Schonewille and Beynen, 2005a) is associated with $\mathrm{Na}$ deficiency in ruminants. In the current study the salivary $\mathrm{Na} / \mathrm{K}$ ratio was 4.8 when the cows were fed the low-Na ration. Such a low Na/K ratio corroborates our conclusion that $\mathrm{Na}$ deficiency occurred when the cows were fed the low-Na ration. 
Table 4. Concentration of sodium $(\mathrm{Na})$ and potassium $(\mathrm{K})$ in saliva and serum of dairy cows fed low-, medium- and high-Na rations

\begin{tabular}{|c|c|c|c|c|c|}
\hline \multirow[t]{2}{*}{ Parameter } & \multicolumn{3}{|c|}{ Treatment } & \multirow[t]{2}{*}{ Pooled SEM } & \multirow[t]{2}{*}{$P$ value } \\
\hline & Low $\mathrm{Na}$ & Medium Na & High $\mathrm{Na}$ & & \\
\hline \multicolumn{6}{|l|}{ Saliva } \\
\hline $\mathrm{Na}, \mathrm{mmol} / \mathrm{L}$ & $95.6^{\mathrm{a}}$ & $121.0^{\mathrm{ab}}$ & $132.0^{\mathrm{b}}$ & 6.2 & 0.033 \\
\hline $\mathrm{K}, \mathrm{mmol} / \mathrm{L}$ & $21.4^{\mathrm{a}}$ & $11.8^{\mathrm{b}}$ & $11.7^{\mathrm{b}}$ & 1.7 & 0.020 \\
\hline $\mathrm{Na} / \mathrm{K}$ ratio & $4.82^{\mathrm{a}}$ & $10.27^{\mathrm{b}}$ & $12.46^{\mathrm{b}}$ & 1.2 & 0.009 \\
\hline \multicolumn{6}{|l|}{ Serum } \\
\hline $\mathrm{Na}, \mathrm{mmol} / \mathrm{L}$ & 139 & 141 & 142 & 1.1 & 0.641 \\
\hline $\mathrm{K}, \mathrm{mmol} / \mathrm{L}$ & 4.0 & 4.0 & 4.1 & 0.1 & 0.999 \\
\hline
\end{tabular}

Means with different letters in a row are significantly different $(P<0.05)$. SEM, standard error of mean.

The apparent $\mathrm{K}$ absorption was greater than $150 \mathrm{~g} / \mathrm{d}$ while $23.6-29.3 \mathrm{~g} / \mathrm{d}$ of $\mathrm{K}$ was excreted in the milk. Inevitable urinary loss of $\mathrm{K}$ is estimated to be $38 \mathrm{mg} / \mathrm{kg}$ body weight (Schonewille and Beynen, 2005b). Thus in cows with a body weight of $485 \mathrm{~kg}$ the inevitable urinary $\mathrm{K}$ losses can be expected to be around $18.4 \mathrm{~g} / \mathrm{d}$. Based on this calculation, approximately $100 \mathrm{~g}$ of $\mathrm{K}$ was available for excretion in sweat, at least in adult, non-pregnant cows. Quantitative data on $\mathrm{K}$ loss through sweating are at least to our knowledge, not available. The clinical signs of $\mathrm{K}$ deficiency are not well documented, but reduced appetite, poor growth, muscular weakness, stiffness paralysis and intracellular acidosis have been reported (Underwood and Suttle, 1999). In the current study the animals appeared healthy, indicating that $\mathrm{K}$ deficiency did not occur during the trial.

The increase in $\mathrm{Na}$ intake did not induce any changes in serum concentrations of $\mathrm{Na}$ and $\mathrm{K}$. These results are consistent with previous studies that reported an increased intake of $\mathrm{Na}$ via supplementation of the diet with $\mathrm{NaCl}$ and $\mathrm{NaHCO}_{3}$ without any effect on plasma $\mathrm{Na}$ concentration (Eicher et al., 2003; O’Connor et al., 1988; Schneider et al., 1984; Tucker and Hogue, 1990). Also, homeostatic regulation, which is controlled by several hormones, can maintain serum $\mathrm{Na}$ levels during $\mathrm{Na}$ deficiency (NRC, 2005). Aldosterone responds to a decline in serum $\mathrm{Na}$ concentration or to systemic low blood pressure. As a result, there is an increase in renal conservation of $\mathrm{Na}$ which increases in renal $\mathrm{K}$ excretion (NRC, 2005). It was reported by Schneider et al. (1986) that plasma $\mathrm{Na}$ concentration increased when $\mathrm{NaHCO}_{3}$ was used to increase dietary Na from 1.8 to $8.8 \mathrm{~g} / \mathrm{kg}$ DM. However, no increase in level of $\mathrm{Na}$ was seen when $\mathrm{NaCl}$ was utilised as $\mathrm{Na}$ source. It should be noted that the present study only 
used the different diets for a period of 37 days, so there is still sufficient $\mathrm{Na}$ present in the body to maintain plasma $\mathrm{Na}$ levels within the normal physiological range even if the cow is fed a low dietary Na concentration.

Milk Na concentration and milk yield $(P<0.292)$ were not affected by the dietary $\mathrm{Na}$ content. The mean milk production for all cows was $15.0 \mathrm{~kg} / \mathrm{d}$ (SE 0.68) which was lower than anticipated. The discrepancy between the predicted and the observed milk yield was at least partially explained by the observed level of DMI. The dietary $\mathrm{NaCl}$ content had no effect on the level of milk production in the current study, which agrees with earlier studies (Coppock et al., 1982; Granzin and Gaughan, 2002). The Na excretion via the milk was numerically lower after feeding the low-Na ration because of lower milk yield (low, 13.7 $\mathrm{kg} / \mathrm{d}$; medium, $14.9 \mathrm{~kg} / \mathrm{d}$; high, $16.4 \mathrm{~kg} / \mathrm{d}$ ). The apparent faecal $\mathrm{Na}$ absorption in cows fed the low-Na diet was equal to the amount of $\mathrm{Na}$ lost in milk. In addition to the losses in milk and faeces, there are some inevitable Na losses in urine (Michell, 1995) as well as losses due to sweating caused by the warm humid conditions (Underwood and Suttle, 1999). Mean minimum and maximum daily temperatures were 24.6 and $34.8{ }^{\circ} \mathrm{C}$ respectively and mean minimum and maximum daily relative humidity were 50.0 and $88.1 \%$ respectively. Because the thermal neutral zone for cows has a temperature humidity index lower than 72 , it is likely that the animals in the present study experienced heat stress during some parts of the day (Hahn and Mader, 1997). Therefore it is speculated that cows fed the low-Na diet were in negative $\mathrm{Na}$ balance owing to the inevitable $\mathrm{Na}$ loss with both urine and sweat. Because cows maintain $\mathrm{Na}$ balance by $\mathrm{Na}$ excretion with urine, it is anticipated that the excess of $\mathrm{Na}$ absorbed by cows fed the medium- and high-Na diets was excreted with urine. The outcome of the current study clearly showed that an Na content of $1.6 \mathrm{~g} / \mathrm{kg} \mathrm{DM}$ was sufficient to meet the $\mathrm{Na}$ requirement of dairy cows under tropical conditions. Clearly, the minimum $\mathrm{Na}$ requirement could not be derived from this study, but the current estimate of the $\mathrm{Na}$ requirement for dairy cows set by the NRC (2001) is too high. On the basis of the data provided in Table 1, a mean Na requirement of $1.2 \mathrm{~g} / \mathrm{kg}$ DM can be calculated. This value is in line with the conclusion of Suttle (2010) who suggested that $1.2 \mathrm{~g} \mathrm{Na} / \mathrm{kg} \mathrm{DM}$ is sufficient for cows with a DMI and milk yield similar to those observed in the current study. Therefore, we propose a tentative value of $1.2 \mathrm{~g} / \mathrm{kg} \mathrm{DM}$ as the $\mathrm{Na}$ requirement for dairy cows under tropical conditions. 


\section{CONCLUSIONS}

A large increase in $\mathrm{Na}$ intake did not induce any changes in serum, faecal and milk $\mathrm{Na}$ concentrations but did affect the Na concentration in the saliva. The salivary $\mathrm{Na} / \mathrm{K}$ ratio was a good indicator of $\mathrm{Na}$ intake by dairy cattle. Consumption of a diet containing $\mathrm{Na}$ at the level recommended by the NRC appears to provide too much Na for lactating cows under tropical conditions.

\section{ACKNOWLEDGMENTS}

The authors gratefully thank Dr Chalong Wachirapakorn for valuable suggestions. The project was supported by the Intervet (Thailand) Ltd., the Faculty of Veterinary Medicine, Kasetsart University and the Kasetsart University Research and Development Institute.

\section{REFERENCES}

Aines, P. D. and S. E. Smith. 1957. Sodium versus chloride for the therapy of salt-deficient dairy cows. J. Dairy Sci.40:682-688.

Agricultural Research Council (ARC). 1980. The Nutrient Requirements of Ruminant Livestock. CAB, Farnham Royal, UK.

Association of Official Analytical Chemists (AOAC). 1990. Official Methods of Analysis. Washington, DC.

Beede, D. K. 1991. Mineral and water nutrition. Vet. Clin. North Am. Food Anim. Pract. 7:373-390.

Bell, F. R. 1995. Perception of sodium and sodium appetite in farm animals, in Sodium in Agriculture, ed. by Phillip C. J. C. and P. C. Chiy. Chalcombe Publications, Canterbury, UK, pp. 82-90.

Blair-West, J. R., J. P. Coghlan, D. A. Denton and R. D. Wright. 1970. Factors affecting sodium and potassium metabolism, in Physiology of Digestion in the Ruminant, ed. by Phillipson A. T. Oriel Press Limited, Newcastle upon Tyne, UK, pp. 350-361.

Central Bureau for Livestock Feeding (CVB). 2005. Handleiding Minerallenvoorziening Rundvee, Schapen, Geiten. Lelystad, the Netherlands.

Coppock, C. E, P. A. Grant, S. J. Portzer and A. Escobosa. 1982. Effect of varying dietary ratio of sodium and chloride on the responses of lactating dairy cows in hot weather. $\mathrm{J}$. Dairy Sci. 65:552-65.

DLG. 2001. Ausschuss für Bedarfsnormen der Gesellschaft für Ernährungsphysiologie; Energie-und Nährstoffbedarf Landwirtschaftlicher Nutztiere. DLG-verlag Nr.8. 
Empfehlungen zur Energie-und Nährstoffversorgung der Milchkühe und Aufzuchtsrinder. DLG-verlag, Frankfurt, pp. 71-88.

Eicher, R., A. Liesegang, E. Fuschini, M. Wanner, P. Rusch and J.Martig. 2003. Evaluation of biochemical methods for estimating the sodium intake of dairy cows. Vet. Rec. 153:358-362.

Granzin, B. C. and J. B. Gaughan. 2002. The effect of sodium chloride supplementation on the milk production of grazing Holstein Friesian cows during summer and autumn in a humid sub-tropical environment. Anim. Feed Sci. Technol. 96:147-160.

Greene, L. W., J. P. Fontenot and Jr. K. E. Webb. 1983a. Site of magnesium and other macromineral absorption in steers fed high levels of potassium. J. Anim. Sci. 57:503510.

Greene, L. W., Jr. K. E. Webb and J. P. Fontenot. 1983b. Effect of potassium level on site of absorption of magnesium and other macroelements in sheep. J. Anim. Sci. 56:12141221.

Gueguen, L., M. Lamand and F. Meschy. 1989. Mineral requirements, in Ruminant Nutrition: Recommended Allowance and Feed Tables, ed. by Jarrige R. INRA/John Libbey, Paris, pp. 49-59.

Hahn, G. L. and T. L. Mader. 1997. Heat waves in relation to thermoregulation, feeding behavior, and mortality of feedlot cattle, in Proceedings of $5^{\text {th }}$ International Livestock Environment Symposium, American Society of Agricultural Engineers, Minneapolis, Minnesota, pp. 563-571.

Hemken, R. W. 1983. Potassium in ruminant nutrition, in Sodium and Potassium in Ruminant Nutrition. West Des Moines: National Feed Ingredients Association, IA, pp.1.

Kemp, A. 1964 Sodium requirement of milking cows: Balance trials with cows on rations of freshly mown herbage and on winter rations. Neth. J. Agric. Sci. 12:263- 280.

Martz, F. A., R. N Ordex, M. F. Weiss and R. L. Belyea. 1988. Mineral balance for growing dairy heifers fed semipurified diets. Nutri. Rep. Int. 38:665-673.

McKeown, J. W. 1986. Disorders of Na metabolism, in Fluids and Electrolytes, ed. by Kakko J. P. and Tannen R. L. W. P. Saunders Co., Philadelphia, pp. 63.

Michell, A. R. 1995. Physiological basis of nutritional requirement for sodium, in The Clinical Biology of Sodium. Elsevier Sci. Publ. Ltd., Oxford, UK, pp. 105-122.

Minson, D. J. 1990. Sodium, in Forage in Ruminant Nutrition. Academic Press, New York, pp. 291-308. 
Morris, J. G., R. E. Delmas and J. L. Hull. 1980. Salt (sodium) supplementation of range beef cows in California. J. Anim. Sci. 51:722-731.

Murphy, G. M. and J. A. Connell. 1970. A simple method of collecting saliva to determine the sodium status of cattle and sheep. Aust. Vet. J. 46:595-598.

National Research Council (NRC). 2001. Nutrient Requirements of Dairy Cattle (7th rev. edn). National Academy Press, Washington, DC.

National Research Council (NRC). 2005. Mineral Tolerance of Animals (2nd edn). National Academy Press, Washington, DC.

O'Connor, A. M., D. K. Beede and C. J. Wilcox. 1988. Lactational responses to dietary magnesium, potassium, and sodium during winter in Florida. J. Dairy Sci. 71:971-981.

Sanchez, W. K., M. A. McGuire and D. K. Beede. 1994. Macromineral nutrition by heat stress interactions in dairy cattle: review and original research. J. Dairy Sci. 77:205179.

Sanchez, W. K., D. K. Beede and J. A. Cornell. 1997. Dietary mixtures of sodium bicarbonate, sodium chloride, and potassium chloride: effects on lactational performance, acid-base status, and mineral metabolism of Holstein cows. J. Dairy Sci. 80:1207-1216.

Schneider, P. L., D. K. Beede, C. J. Wilcox and R. J. Collier. 1984. Influence of dietary sodium and potassium bicarbonate and total potassium on heat-stressed lactating dairy cows. J. Dairy Sci. 67:2546-2553.

Schneider, P. L., D. K. Beede and C. J. Wilcox. 1986. Responses of lactating cows to dietary sodium source and quantity and potassium quantity during heat stress. J. Dairy Sci. 69:99-110

Schonewille, J. T. and A. C. Beynen. 2005a. Reviews on the mineral provision in ruminants (IV). CVB Documentation Report Nr 36, Central Bureau for Livestock Feeding. The Netherlands

Schonewille, J. T. and A. C. Beynen 2005b. Reviews on the mineral provision in ruminants (V). CVB Documentation Report Nr 37, Central Bureau for Livestock Feeding. The Netherlands

Shimadzu Cook Handbook. 2007. Atomic Absorption Spectrophotometry Cookbook. Shimadzu Co., Kyoto, Japan.

Silanikove, N., E. Maltz, D. Shinder, E. Bogin, T. Bastholm, N. J. Christensen and P. Norggarrd. 1998. Metabolic and productive responses of dairy cows to increased ion supplementation at early lactation in warm weather. J. Dairy Res. 65:529-543. 
Suttle, N. F. 2010. Sodium and Chloride, in The Mineral Nutrition of Livestock (4th edn), ed. by Suttle N. F. CABI, London, UK, pp. 182-205.

Tucker, W. B. and J. F. Hogue.1990. Influence of sodium chloride or potassium chloride on systemic acid-base status, milk yield, and mineral metabolism in lactating dairy cows. J. Dairy Sci.73:3485-3493.

Underwood, E. J. and N. F. Suttle. 1999. Sodium and Chlorine, in The Mineral Nutrition of Livestock (3rd edn.). CABI, New York, NY, pp. 185-229. 


\section{Chapter 4}

\section{Response of Saliva Na/K Ratio to Changing Na Supply of Lactating Cows under Tropical Conditions}

Wandee Thiangtum ${ }^{1}$, J Thomas Schonewille ${ }^{2,3}$, Martin WA Verstegen ${ }^{4}$, Supot Arsawakulsudhi ${ }^{1}$, Theera Rukkwamsuk ${ }^{1}$ and Wouter H Hendriks ${ }^{2,4}$

\footnotetext{
${ }^{1}$ Department of Large Animal and Wildlife Clinical Sciences, Faculty of Veterinary Medicine, Kasetsart University, Thailand

${ }^{2}$ Department of Farm Animal Health, Faculty of Veterinary Medicine, Utrecht University, The Netherlands

${ }^{3}$ Department of Agricultural Technology and Environment, Faculty of Sciences and Liberal Arts, Rajamangala University of Technology Isan, Thailand

${ }^{4}$ Department of Animal Sciences, Wageningen University, Wageningen, The Netherlands
}

Journal of the Science of Food and Agriculture (2017) 97:2480-2486 


\begin{abstract}
Factorial determination of the sodium $(\mathrm{Na})$ requirement of heat-stressed lactating cows is hindered by accurate estimates of the Na losses through sweat. Direct studies, therefore, may be needed requiring information on the time course of healthy animals to become Na depleted and the subsequent rate of repletion. The rate of $\mathrm{Na}$ depletion and subsequent rate of $\mathrm{Na}$ repletion with two levels of dietary $\mathrm{Na}$ to lactating dairy cows housed under tropical conditions were investigated using the salivary $\mathrm{Na} / \mathrm{K}$. The 12 lactating cows (salivary $\mathrm{Na} / \mathrm{K}$ ratio 14.6) rapidly developed clinical signs of $\mathrm{Na}$ deficiency, including pica, polyuria and polydipsia, reduced body weight and reduced milk yield when fed a low-Na ration $(0.33 \mathrm{~g} / \mathrm{kg}$ dry matter (DM)) for 3 weeks. Deficiency symptoms were associated with a rapid decrease in salivary $\mathrm{Na} / \mathrm{K}$ ratio to $<4.3$ from 7 to 21 days. Subsequent repletion of the cows with $\mathrm{NaCl}$ to a ration concentration of 1.1 or $1.6 \mathrm{~g} \mathrm{Na} / \mathrm{kg} \mathrm{DM}$ for 5 weeks did not restore salivary $\mathrm{Na} / \mathrm{K}$ ratio to values of $>6$. A daily $\mathrm{Na}$ intake of heat-stressed lactating cows to a ration intake of $1.6 \mathrm{~g} \mathrm{Na} / \mathrm{kg} \mathrm{DM}$ was insufficient to restore $\mathrm{Na}$ deficiency. One week was sufficient to deplete heat-stressed lactating cows of $\mathrm{Na}$, allowing for rapid dose-response studies utilizing the salivary $\mathrm{Na} / \mathrm{K}$ ratio as a parameter for $\mathrm{Na}$ status of cows under tropical conditions.
\end{abstract}




\section{INTRODUCTION}

Sodium (Na) is essential for dairy cows to maintain water balance: in the event of $\mathrm{Na}$ deficiency polyuria and polydipsia occur (Whitlock et al., 1975). Furthermore, Na deficiency is associated with clinical signs such as pica, loss of appetite and a decreased milk yield in dairy cows (Suttle, 2010a). Sodium is also a major component of salts in saliva to buffer acid generated during ruminal fermentation (Blair-West et al., 1963). It is generally accepted that in Na-deficient ruminants the salivary $\mathrm{Na}$ concentration decreases to a value below 120 $\mathrm{mmol} / \mathrm{L}$ with a concomitant increase in salivary potassium $(\mathrm{K})$ concentration. As such, the use of the salivary $\mathrm{Na} / \mathrm{K}$ is a sensitive diagnostic tool to detect $\mathrm{Na}$ deficiency in ruminants (Schonewille and Beynen, 2005). Previously, Thiangtum et al. (2011) showed the value of salivary $\mathrm{Na} / \mathrm{K}$ in detecting $\mathrm{Na}$ deficiency in dairy cows housed under tropical conditions.

The current recommendations regarding an adequate Na supply for dairy cows ranges from 0.7 to $2.2 \mathrm{~g} / \mathrm{kg}$ dry matter (DM) (ARC, 1980; CBV, 2005; DLG, 2001; INRA, 1989; NRC, 2001). However, these recommendations were derived from studies with animals housed under temperate conditions and thus do not take into account $\mathrm{Na}$ loss through sweating (Sanchez et al., 1994) during heat stress. Indeed, it was suggested by Sanchez et al. (1994) that the $\mathrm{Na}$ requirement is increased during heat stress due to the higher $\mathrm{Na}$ loss associated with sweating. Furthermore, Schneider et al. (1986) reported an increased DM intake when the $\mathrm{Na}$ content of rations of lactating cows during heat stress was raised from 1.8 to $5.5 \mathrm{~g} / \mathrm{kg} \mathrm{DM}$. The issue of $\mathrm{Na}$ requirement of dairy cows in tropical countries was addressed by Thiangtum et al. (2011), who arbitrarily suggested that dairy cows require a dietary $\mathrm{Na}$ content of $1.2 \mathrm{~g} / \mathrm{kg} \mathrm{DM}$ under tropical conditions. However, generalization of this tentative value of $1.2 \mathrm{~g} \mathrm{Na} / \mathrm{kg} \mathrm{DM}$ is currently not warranted owing to a dearth of studies addressing the issue of Na requirements of dairy cattle in the Tropics.

The assessment of $\mathrm{Na}$ requirement of heat-stressed dairy cows is hindered by the fact that $\mathrm{Na}$ losses through sweat are difficult to quantify, and therefore direct studies of the $\mathrm{Na}$ requirements under tropical conditions are needed. Important information for such studies is the time course of healthy animals to become deplete of $\mathrm{Na}$ and the subsequent rate of repletion. In the current study, the rate of $\mathrm{Na}$ depletion and subsequent rate of $\mathrm{Na}$ repletion using two levels of dietary $\mathrm{Na}$ were investigated using salivary $\mathrm{Na} / \mathrm{K}$ in heat-stressed lactating dairy cows. Lactating cows were initially fed a Na low ration $(0.33 \mathrm{~g} / \mathrm{kg} \mathrm{DM})$ for 3 weeks before being provided supplemental $\mathrm{NaCl}$ to a dietary concentration of $1.2 \mathrm{~g}$ ( $\mathrm{LNa}$ ) or $1.7 \mathrm{~g}$ $\mathrm{Na} / \mathrm{kg} \mathrm{DM}(\mathrm{HNa})$. The aim of the current study was to determine both the rate of depletion 
and repletion and it was hypothesized that high versus low Na repletion would restore the salivary $\mathrm{Na} / \mathrm{K}$ ratio more rapidly.

\section{MATERIALS AND METHODS}

\section{Animals and management}

Twelve cross-bred (Holstein Friesian $x$ indigenous) multiparous cows with a mean body weight $(\mathrm{BW})$ of $476 \mathrm{~kg}(\mathrm{SD}=43)$ and $61(\mathrm{SD}=37)$ days in milk were used. The cows were housed individually in a tie stall for a period of 8 weeks. The experiment was conducted during the summer season from the end of February to April. Ambient temperature and relative humidity inside the stall were recorded every 2 hours from 10:00 Friday to 10:00 Saturday during the experiment (Maxim's iButton devices, San Jose, CA, USA).Temperature and relative humidity records were also obtained from the Nakhon Pathom meteorological station, located $500 \mathrm{~m}$ from the dairy barn of Kasetsart University (Kamphaengsaen, Nakhon Pathom, Thailand). Rectal temperature of each cow was measured weekly on Friday between 09:00 and 10:00. Cows were fed individually four times daily at 02:00, 07:00, 15:00 and 21:00 and the animals had free access to water. $24 \mathrm{~h}$ water intake was recorded between 09:00 and 10:00. The cows were milked twice daily and milk production was recorded at 14:30 Friday and 05:30 Saturday. BW was measured on days 0, 20 and 56 of the experiment.

\section{Experimental design and rations}

The experiment consisted of a depletion and a repletion period, with all cows offered the Nadeficient, total mixed ration (TMR, Table 1) ad libitum each day throughout the experiment. Orts for each individual cow were collected daily. After the 3-week depletion period, cows were blocked by milk yield and, within each block, cows were randomly allocated to either LNa or HNa. Dry matter intake observed during weeks 2 and 3 was used to determine the amount of supplemental $\mathrm{NaCl}$ to achieve 1.2 and $1.7 \mathrm{~g} \mathrm{Na} / \mathrm{kg} \mathrm{DM}$, resulting in a supplementation of 23.5 and $38.7 \mathrm{~g} / \mathrm{day}$ of $\mathrm{NaCl}$, respectively. During the 5-week repletion period, supplemental $\mathrm{NaCl}$ was offered daily to each cow in two equal portions fed at 10:00 and 15:00. Throughout the repletion period, all cows consumed all the supplemental salt offered. 
Table 1. Ingredient and nutrient composition of the basal ration

\begin{tabular}{|c|c|}
\hline Component & Content \\
\hline \multicolumn{2}{|l|}{ Ingredient composition, (g/kg as fed) } \\
\hline Rice straw & 200.0 \\
\hline Cassava chips & 420.0 \\
\hline Cotton seed & 100.0 \\
\hline Soybean meal & 120.0 \\
\hline Brewer's grain & 50.0 \\
\hline Coconut oil & 10.0 \\
\hline Molasses & 64.0 \\
\hline Urea & 18.0 \\
\hline Calcium phosphate & 7.0 \\
\hline $\mathrm{MgO}$ & 3.0 \\
\hline Sulphur & 3.0 \\
\hline Premix $^{a}$ & 5.0 \\
\hline \multicolumn{2}{|l|}{ Analysed nutrient composition } \\
\hline Dry matter (DM, g/kg as fed) & 903.0 \\
\hline Crude protein $(\mathrm{g} / \mathrm{kg} \mathrm{DM})$ & 144.3 \\
\hline Ether extract (g/kg DM) & 62.5 \\
\hline Neutral detergent fibre (g/kg DM) & 275.4 \\
\hline Acid detergent fibre (g/kg DM) & 207.2 \\
\hline Sodium (g/kg DM) & 0.33 \\
\hline Potassium (g/kg DM) & 10.5 \\
\hline
\end{tabular}

${ }^{a}$ The mineral premix consists of 440,000 IU vitamin A, 60,000 IU vitamin D3, 30,000 IU vitamin E, $11.6 \mathrm{~g} \mathrm{Fe}, 0.03 \mathrm{~g} \mathrm{Mn}, 5.6 \mathrm{~g} \mathrm{Cu}, 11.60 \mathrm{~g} \mathrm{Zn}, 0.07 \mathrm{~g} \mathrm{I}, 0.06 \mathrm{~g}$ $\mathrm{Se}, 10.0 \mathrm{~g} \mathrm{Mg}$ and $15.0 \mathrm{~g} \mathrm{P}$ per $\mathrm{kg}$.

\section{Sample collection and chemical analyses}

Samples of TMR $(\sim 2 \mathrm{~kg})$ were collected weekly, dried at $60{ }^{\circ} \mathrm{C}$, ground and pooled before analysis of dry matter, crude protein and ether extract according to AOAC procedures (1990). Neutral detergent fibre and acid detergent fibre were analysed according the method described by Van Soest et al. (1991). During the depletion period and approximately $30 \mathrm{~min}$ prior to the supplementation of salt during the repletion period, saliva samples were collected each Friday by placing sponges in the mouths of the cows at the third premolar in the maxilla for a period of 3 min. Subsequently, the liquid in the sponges was collected into a plastic bag, transferred 
to a tube and stored at $-20{ }^{\circ} \mathrm{C}$ until mineral analysis. Blood samples $(\sim 10 \mathrm{~mL})$ were collected from the jugular vein of each cow on each Friday at 10:00. Serum samples were obtained by centrifuging blood samples at $800 \times g$ for $5 \mathrm{~min}$. All serum samples were stored at $-20{ }^{\circ} \mathrm{C}$ until mineral analysis by means of a blood gas analyzer (Nova Biomedical Corporation, Waltham, MA, USA). A milk sample $(\sim 30 \mathrm{~mL})$ of the Friday pm and Saturday am milking of each cow was collected in a tube containing $0.2 \mathrm{~g} / \mathrm{L}$ of 2-bromo-2-nitro-1, 3-propanediol. Preserved milk samples were pooled in proportion to the milk yield of each milking, and stored at $4{ }^{\circ} \mathrm{C}$. The following Monday, fat was removed manually and milk was deproteinated by adding $10 \%$ trichloroacetic acid, vortexed and centrifuged at $800 \times g$ for $10 \mathrm{~min}$. The collected supernatant was stored at $-18{ }^{\circ} \mathrm{C}$ until mineral analysis.

During the repletion period, urine was quantitatively collected from each cow for $24 \mathrm{~h}$ every Friday. Urine was collected manually either through manual stimulation of the vulva or collection of urine that was spontaneously voided. After $24 \mathrm{~h}$, total urine volume was recorded, thoroughly mixed and a sample $(\sim 100 \mathrm{~mL})$ stored at $-20{ }^{\circ} \mathrm{C}$ until analysis.

All samples of milk, saliva, urine and feed were analysed for $\mathrm{Na}$ and $\mathrm{K}$ using a flame emission atomic absorption spectrophotometer (AA-6800, Shimadzu, Kyoto, Japan) in accordance with the manufacturer's specifications.

\section{Calculations and statistical analysis}

The temperature humidity index (THI) was calculated according to the following formula (NRC, 1971):

$$
\mathrm{THI}=\left(1.8 \times \mathrm{T}_{\mathrm{db}}+32\right)-\left[(0.55-0.0055 \times \mathrm{RH}) \times\left(1.8 \times \mathrm{T}_{\mathrm{db}}-26\right)\right]
$$

where: $\mathrm{T}_{\mathrm{db}}=$ dry bulb temperature $\left({ }^{\circ} \mathrm{C}\right)$ and $\mathrm{RH}=$ relative humidity $(\%)$. Data from the depletion period were subjected to repeated-measures analysis of variance (ANOVA). The data from the repletion period were subjected to repeated-measures ANOVA with block and sodium treatment as factors, with the corresponding data of week 2 of the depletion period as a covariate. All statistical analyses were performed using SPSS for Windows (SPSS Inc.,

Chicago, IL, USA). Time effects were tested by mean of orthogonal polynomials. The level of statistical significance was pre-set at a probability level below 0.05 with a trend considered of $0.10<P \leq 0.05$. 


\section{RESULTS}

During the depletion period, the daily THI calculated from the temperature and humidity inside the barn ranged from 79.5 to 83.1 (Figure 1) with a mean value of 81.6 (SD 1.5). The temperature and humidity recorded in the barn agreed closely with the values recorded by the meteorological station located nearby (Figure 1). Likewise, a similar range in THI was measured during the repletion period and a mean daily THI value of 82.6 (SD 0.8) was found. Despite the high THI, cows were able to maintain their body temperature within the physiological range during both the depletion and repletion period and, for the two periods combined, the group mean values ranged between 37.9 and $38.9{ }^{\circ} \mathrm{C}$.
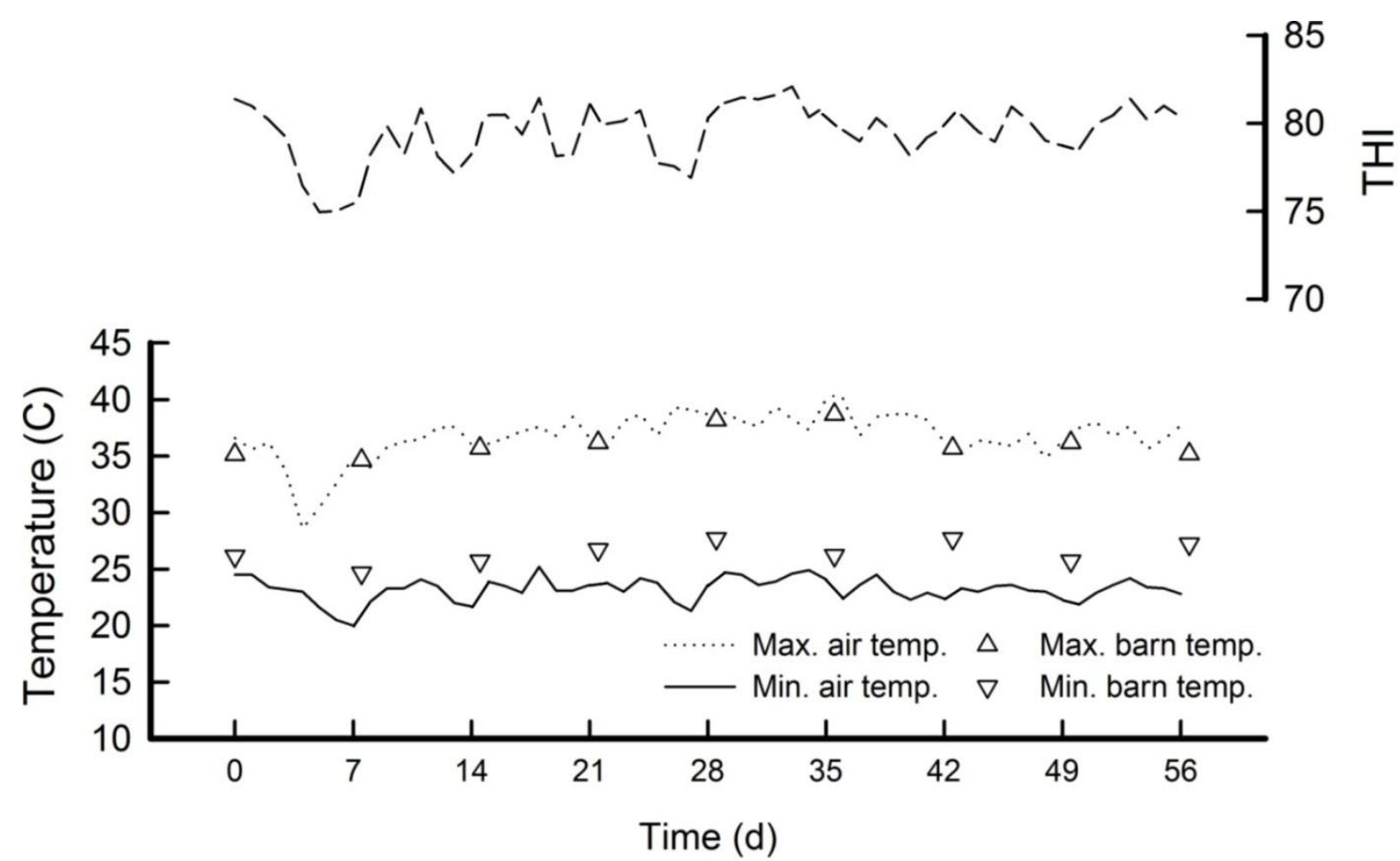

Figure 1. Atmospheric and barn temperatures (maximum and minimum) and temperature humidity index (THI) during the 56 day experiment. 
Table 2. Dry matter (DM) intake, milk yield, water intake, urine production and concentrations of sodium and potassium in saliva and serum in the course of the depletion period

\begin{tabular}{|c|c|c|c|c|c|c|}
\hline \multirow[t]{2}{*}{ Item } & \multicolumn{4}{|c|}{ Days of Na depletion } & \multirow[t]{2}{*}{ SEM } & \multirow{2}{*}{$\begin{array}{c}\text { Significance of } \\
\text { time effect }\end{array}$} \\
\hline & 0 & 7 & 14 & 21 & & \\
\hline DM intake $(\mathrm{kg} / \mathrm{d})$ & 12.5 & 12.3 & 11.8 & 10.8 & 0.7 & NS \\
\hline Milk yield (L/d) & 16.9 & 13.7 & 12.9 & 14.3 & 0.6 & $\mathrm{~L}, \mathrm{Q}$ \\
\hline Water intake (L/d) & 71 & 89 & 94 & 123 & 7.9 & $\mathrm{~L}$ \\
\hline Urine production $(\mathrm{L} / \mathrm{d})$ & 23 & 26 & 39 & 58 & 6.1 & $\mathrm{~L}, \mathrm{Q}$ \\
\hline \multicolumn{7}{|l|}{ Saliva } \\
\hline $\mathrm{Na}(\mathrm{mmol} / \mathrm{L})$ & 128.7 & 97.7 & 82.1 & 98.1 & 4.2 & $\mathrm{~L}, \mathrm{Q}$ \\
\hline $\mathrm{K}(\mathrm{mmol} / \mathrm{L})$ & 10.2 & 28.8 & 26.9 & 26.7 & 1.8 & $\mathrm{~L}, \mathrm{Q}$ \\
\hline $\mathrm{Na} / \mathrm{K}$ & 14.6 & 3.8 & 3.4 & 4.3 & 0.6 & $\mathrm{~L}, \mathrm{Q}$ \\
\hline \multicolumn{7}{|l|}{ Serum } \\
\hline $\mathrm{Na}(\mathrm{mmol} / \mathrm{L})$ & 138 & 136 & 138 & 138 & 0.3 & Q \\
\hline $\mathrm{K}(\mathrm{mmol} / \mathrm{L})$ & 4.5 & 2.7 & 3.1 & 3.4 & 0.1 & $\mathrm{~L}, \mathrm{Q}$ \\
\hline
\end{tabular}

SEM, standard error of mean; NS, not significant; L, linear; Q, quadratic.

\section{Depletion period}

BW of the cows decreased $(P<0.001)$ from 476 (SD 43.2, $n=12)$ to $426 \mathrm{~kg}(\mathrm{SD} 47.0, n=$ 12) during the 3-week depletion period. Likewise, DM intake decreased from 12.5 to 10.8 $\mathrm{kg} / \mathrm{d}$ (Table 2) during the depletion period but the difference in DM intake over time was not statistically significant. In contrast, milk yield was $15.4 \%$ lower $(P<0.001)$ at the end of the depletion period compared to initial yield. Both water intake and urine production significantly increased during the depletion period, and values were found to be 1.7 and 2.5 times greater respectively, at the end of the depletion period compared to the initial values. In addition, pica and skin licking were observed starting at 7 days. Salivary Na concentration significantly decreased, with a concomitant increase in salivary K concentrations (Table 2), and values of 98.1 and $26.7 \mathrm{mmol} / \mathrm{L}$, respectively, were observed at the end of the depletion period. Furthermore, the salivary $\mathrm{Na} / \mathrm{K}$ ratio was found to decrease significantly during the depletion period, with a value at 7 days already significantly lower than the value found at the start of the depletion period. Serum $\mathrm{Na}$ and $\mathrm{K}$ concentrations responded in a quadratic fashion over time and the lowest values were found 7 days after the start of the depletion period, i.e. 136 and $2.7 \mathrm{mmol} / \mathrm{L}$, respectively (Table 2). However, in contrast to serum Na concentrations, serum $\mathrm{K}$ values at the end of the depletion period were found to be $24.4 \%$ lower than the value at day 0 . 


\section{Repletion period}

BW of the cows remained unchanged $(P=0.121)$ and was similar between $\mathrm{Na}$ intake $(P=$ 0.893 ) during the repletion period. Across time and Na intake, mean BW was found to be 433 $\mathrm{kg}$ (SD 8.6). Dry matter intake was neither influenced by the amount of supplemented salt nor by time $\times \mathrm{Na}$ intake. However, for DM intake a quadratic time trend was observed during the repletion period (Table 3). Milk yield did not respond to the increase in DM intake and remained constant throughout the repletion period. Furthermore, milk yield was similar for the two levels of $\mathrm{Na}$ intakes and, across time and for the two $\mathrm{Na}$ intakes combined, it was found to be 14.6 L/day (SD 2.8). The intake of water was neither affected by Na intake nor by time or by time $\times \mathrm{Na}$ intake. Average water intake of the two groups over the 5 weekrepletion period was $120 \mathrm{~L} / \mathrm{d}$. Likewise, urine production was not affected by the amount of supplemented salt, and urine production over time (Table 3) was not significant; however, a time $\times \mathrm{Na}$ intake trend $(P=0.063)$ was observed.

During the repletion period, interactions between time and $\mathrm{Na}$ intake did not occur with respect to the intakes of $\mathrm{Na}$ and $\mathrm{K}$ and their respective excretions with milk and urine (Table 4). Sodium intake was significantly different between the two levels of salt supplementation. Furthermore, a quadratic trend of $\mathrm{Na}$ intake over time was found and this observation is in line with the observed time trend of DM intake during the repletion period. Likewise, for $\mathrm{K}$ intake also a quadratic time trend was found but $\mathrm{K}$ intakes were similar between the two levels of $\mathrm{Na}$ intake (Table 4). Na excretion with urine was not significantly different between the two levels of salt supplementation or between the different time points (Table 4). For all time points combined, mean urinary Na excretion was found to be 0.3 and $1.7 \mathrm{~g} / \mathrm{d}$ for the LNa and HNa group, respectively. K excretion with urine showed a linear trend $(P=0.055)$ over time, while no effect was found for $\mathrm{Na}$ intake or the interaction between time and $\mathrm{Na}$ intake. The $\mathrm{Na}$ and $\mathrm{K}$ concentrations of milk (data not shown) increased linearly $(P<$ 0.024 ) in time, i.e. from 0.33 to $0.35 \mathrm{~g} / \mathrm{L}$ and from 1.47 to $1.65 \mathrm{~g} / \mathrm{L}$, respectively. These increases were independent $(P>0.559)$ from the amount of supplemental salt and were not affected $(P>0.281)$ by time $\times \mathrm{Na}$ intake. Sodium and $\mathrm{K}$ excretion with milk was not influenced by $\mathrm{Na}$ intake, time or their interaction (Table 4). For the two Na intakes combined, the mean $\mathrm{Na}$ and $\mathrm{K}$ excretion with milk over the repletion period was found to be 5.1 and 23.1 $\mathrm{g} / \mathrm{d}$, respectively.

There was no effect observed for salivary $\mathrm{Na}$ concentrations due to the supplementation of $\mathrm{Na}$ (Table 5). Furthermore, salivary $\mathrm{Na}$ concentrations were not affected 
by time $\times \mathrm{Na}$ intake but a linear trend $(P=0.050)$ in time was observed. Neither the salivary $\mathrm{K}$ concentrations nor the salivary $\mathrm{Na} / \mathrm{K}$ ratio was statistically different between the dietary $\mathrm{Na}$ intake (Table 5) and no time or interaction was found. The serum concentrations of $\mathrm{Na}$ and $\mathrm{K}$ were not influenced by the amount of supplemental salt, time or by time $\times \mathrm{Na}$ intake (Table $5)$. 
Table 3. Dry matter (DM) intake, milk yield, water intake and urine production in the course of the repletion period

\begin{tabular}{|c|c|c|c|c|c|c|c|c|c|c|c|}
\hline \multirow[t]{2}{*}{ Item } & \multirow[t]{2}{*}{ Na intake } & \multicolumn{6}{|c|}{ Days of Na repletion } & \multirow[t]{2}{*}{ SEM } & \multicolumn{3}{|c|}{ Significance } \\
\hline & & 0 & 7 & 14 & 21 & 28 & 35 & & Time & $\mathrm{Na}$ intake & Time $\times \mathrm{Na}$ intake \\
\hline \multirow[t]{2}{*}{ DM intake $(\mathrm{kg} / \mathrm{d})$} & Low & 11.4 & 11.4 & 12.3 & 11.9 & 13.6 & 13.3 & \multirow{2}{*}{0.88} & \multirow{2}{*}{$\mathrm{Q}^{\mathrm{a}}$} & \multirow{2}{*}{ NS } & \multirow{2}{*}{ NS } \\
\hline & High & 10.2 & 10.6 & 13.0 & 12.6 & 13.1 & 13.7 & & & & \\
\hline \multirow[t]{2}{*}{ Milk yield (L/d) } & Low & 14.2 & 14.5 & 14.8 & 15.2 & 13.4 & 14.2 & \multirow{2}{*}{0.56} & \multirow{2}{*}{ NS } & \multirow{2}{*}{ NS } & \multirow{2}{*}{ NS } \\
\hline & High & 14.4 & 15.2 & 15.4 & 14.9 & 15.2 & 14.1 & & & & \\
\hline \multirow[t]{2}{*}{ Water intake $(\mathrm{L} / \mathrm{d})$} & Low & 97 & 104 & 106 & 117 & 102 & 105 & \multirow{2}{*}{16.1} & \multirow{2}{*}{ NS } & \multirow{2}{*}{ NS } & \multirow{2}{*}{ NS } \\
\hline & High & 148 & 122 & 151 & 143 & 121 & 125 & & & & \\
\hline \multirow[t]{2}{*}{ Urine production $(\mathrm{L} / \mathrm{d})$} & Low & 40 & 37 & 38 & 49 & 35 & 37 & \multirow{2}{*}{14.0} & \multirow{2}{*}{ NS } & \multirow{2}{*}{ NS } & \multirow{2}{*}{$\mathrm{L}^{\mathrm{a}}$} \\
\hline & High & 75 & 57 & 73 & 68 & 56 & 50 & & & & \\
\hline
\end{tabular}

SEM, standard error of mean; NS, not significant; L, linear; Q, quadratic.

${ }^{\mathrm{a}}$ Trend $(0.10<P \leq 0.05)$. 
Table 4. Intake and excretions by means of milk and urine of sodium and potassium during the repletion period

\begin{tabular}{|c|c|c|c|c|c|c|c|c|c|c|c|}
\hline \multirow[t]{2}{*}{ Item } & \multirow[t]{2}{*}{$\mathrm{Na}$ intake } & \multicolumn{6}{|c|}{ Days of Na repletion } & \multirow[t]{2}{*}{ SEM } & \multicolumn{3}{|c|}{ Significance } \\
\hline & & 0 & 7 & 14 & 21 & 28 & 35 & & Time & $\mathrm{Na}$ intake & Time $\times \mathrm{Na}$ intake \\
\hline \multicolumn{12}{|c|}{ Sodium $(\mathrm{g} / \mathrm{d})$} \\
\hline \multirow[t]{2}{*}{ Intake } & Low & 13.0 & 13.0 & 13.3 & 13.2 & 13.8 & 13.7 & \multirow{2}{*}{0.29} & \multirow{2}{*}{$\mathrm{Q}^{\mathrm{a}}$} & \multirow{2}{*}{$<0.001$} & \multirow{2}{*}{ NS } \\
\hline & High & 18.6 & 18.8 & 19.5 & 19.4 & 19.6 & 19.8 & & & & \\
\hline \multirow[t]{2}{*}{ Milk } & Low & 4.7 & 4.5 & 4.9 & 5.7 & 5.0 & 4.9 & \multirow{2}{*}{0.51} & \multirow{2}{*}{ NS } & \multirow{2}{*}{ NS } & \multirow{2}{*}{ NS } \\
\hline & High & 4.9 & 5.0 & 5.6 & 5.2 & 5.6 & 5.0 & & & & \\
\hline \multirow[t]{2}{*}{ Urine } & Low & 0.3 & 0.3 & 0.2 & 0.2 & 0.2 & 0.7 & \multirow{2}{*}{0.38} & \multirow{2}{*}{ NS } & \multirow{2}{*}{ NS } & \multirow{2}{*}{ NS } \\
\hline & High & 1.0 & 2.4 & 1.7 & 1.1 & 1.2 & 2.9 & & & & \\
\hline \multicolumn{12}{|c|}{ Potassium (g/d) } \\
\hline \multirow[t]{2}{*}{ Intake } & Low & 119 & 119 & 128 & 124 & 142 & 139 & \multirow{2}{*}{9.25} & \multirow{2}{*}{$\mathrm{Q}^{\mathrm{a}}$} & \multirow{2}{*}{ NS } & \multirow{2}{*}{ NS } \\
\hline & High & 107 & 111 & 136 & 132 & 136 & 143 & & & & \\
\hline \multirow[t]{2}{*}{ Milk } & Low & 21.1 & 21.9 & 24.3 & 26.4 & 21.6 & 23.5 & \multirow{2}{*}{0.73} & \multirow{2}{*}{ NS } & \multirow{2}{*}{ NS } & \multirow{2}{*}{ NS } \\
\hline & High & 20.9 & 22.5 & 23.4 & 24.8 & 23.9 & 23.2 & & & & \\
\hline \multirow[t]{2}{*}{ Urine } & Low & 65.8 & 73.5 & 56.2 & 67.8 & 69.0 & 85.5 & \multirow{2}{*}{6.69} & \multirow{2}{*}{$\mathrm{L}^{\mathrm{a}}$} & NS & NS \\
\hline & High & 68.7 & 72.4 & 67.0 & 63.0 & 96.0 & 83.7 & & & NS & NS \\
\hline
\end{tabular}

SEM, standard error of mean; NS, not significant; L, linear; Q, quadratic.

${ }^{\mathrm{a}}$ Trend $(0.10<P \leq 0.05)$. 
Table 5. The concentrations of sodium and potassium in saliva and serum during the repletion period

\begin{tabular}{|c|c|c|c|c|c|c|c|c|c|c|c|}
\hline \multirow[t]{2}{*}{ Item } & \multirow[t]{2}{*}{ Na intake } & \multicolumn{6}{|c|}{ Days of Na repletion } & \multirow[t]{2}{*}{ SEM } & \multicolumn{3}{|c|}{ Significance } \\
\hline & & 0 & 7 & 14 & 21 & 28 & 35 & & Time & $\mathrm{Na}$ intake & Time $\times \mathrm{Na}$ intake \\
\hline \multicolumn{12}{|l|}{ Saliva } \\
\hline \multirow[t]{2}{*}{$\mathrm{Na}(\mathrm{mmol} / \mathrm{L})$} & Low & 88 & 104 & 88 & 85 & 91 & 100 & \multirow{2}{*}{3.10} & \multirow{2}{*}{$\mathrm{L}^{\mathrm{a}}$} & \multirow{2}{*}{ NS } & \multirow{2}{*}{ NS } \\
\hline & High & 108 & 108 & 104 & 95 & 100 & 103 & & & & \\
\hline \multirow[t]{2}{*}{$\mathrm{K}(\mathrm{mmol} / \mathrm{L})$} & Low & 31.8 & 44.2 & 35.1 & 39.2 & 36.7 & 31.2 & \multirow{2}{*}{2.20} & \multirow{2}{*}{ NS } & \multirow{2}{*}{ NS } & \multirow{2}{*}{ NS } \\
\hline & High & 21.5 & 26.1 & 27.6 & 26.3 & 28.6 & 25.5 & & & & \\
\hline \multirow[t]{2}{*}{$\mathrm{Na} / \mathrm{K}$} & Low & 3.4 & 2.4 & 2.6 & 2.3 & 2.9 & 3.4 & \multirow{2}{*}{0.29} & \multirow{2}{*}{ NS } & \multirow{2}{*}{ NS } & \multirow{2}{*}{ NS } \\
\hline & High & 5.3 & 4.3 & 3.8 & 3.8 & 3.6 & 4.7 & & & & \\
\hline \multicolumn{12}{|l|}{ Serum } \\
\hline \multirow[t]{2}{*}{$\mathrm{Na}(\mathrm{mmol} / \mathrm{L})$} & Low & 138 & 138 & 137 & 139 & 138 & 140 & \multirow{2}{*}{0.37} & \multirow{2}{*}{ NS } & \multirow{2}{*}{ NS } & \multirow{2}{*}{ NS } \\
\hline & High & 138 & 139 & 138 & 139 & 139 & 140 & & & & \\
\hline \multirow[t]{2}{*}{$\mathrm{K}(\mathrm{mmol} / \mathrm{L})$} & Low & 3.5 & 3.4 & 3.5 & 3.5 & 3.4 & 3.4 & \multirow{2}{*}{0.09} & \multirow{2}{*}{ NS } & \multirow{2}{*}{ NS } & \multirow{2}{*}{ NS } \\
\hline & High & 3.4 & 4.0 & 3.8 & 3.6 & 3.5 & 3.7 & & & & \\
\hline
\end{tabular}

SEM, standard error of mean; NS, not significant; L, linear.

${ }^{\mathrm{a}}$ Trend $(0.10<P \leq 0.05)$. 


\section{DISCUSSION}

During the depletion period, cows developed clinical signs of Na deficiency such as polyuria, polydipsia, pica and a decrease in milk yield, 1 to 2 weeks after the start of feeding of the ration containing $0.33 \mathrm{~g} \mathrm{Na} / \mathrm{kg} \mathrm{DM}$. The occurrence of polyuria and polydipsia during $\mathrm{Na}$ deficiency is caused by the inability of the cow to maintain the osmotic pressure of the extracellular fluid (ECF). Briefly, $\mathrm{Na}$ is the main cation of the ECF and, together with its associated anions, it accounts for more than $90 \%$ of the osmotic pressure of the ECF (Houpt, 1993). A deficit of $\mathrm{Na}$ in the ECF hampers the release of antidiuretic hormone (ADH), thereby causing a rapid renal excretion of excess water to counteract the initial decrease of the $\mathrm{Na}$ concentration of the ECF (Houpt, 1993). However, at this stage the volume of the ECF is lowered, which triggers activation of angiotensin II, leading to an increased water intake to restore the volume of ECF (Blair-West et al., 1988). Clearly, the latter action leads to lower $\mathrm{Na}$ concentrations of the ECF, thereby triggering the aforementioned physiological actions. The clinical observations of $\mathrm{Na}$ deficiency were associated with decreased salivary $\mathrm{Na}$ and increased salivary $K$ concentrations, leading to a salivary $\mathrm{Na} / \mathrm{K}$ ratio of $<4.3$, which is indicative of $\mathrm{Na}$ deficiency (McSweeney et al., 1988). The current observations on salivary $\mathrm{Na}$ and $\mathrm{K}$ concentrations are in line with data reported by Thiangtum et al. (2011) who reported that the salivary $\mathrm{Na} / \mathrm{K}$ ratio decreased to 4.8 when a ration was fed containing $0.4 \mathrm{~g}$ of $\mathrm{Na} / \mathrm{kg} \mathrm{DM}$ for 32 days. In the latter study, however, no clinical signs such as pica were observed. The observed changes in salivary electrolyte concentrations are most likely explained by the action of aldosterone, because it has been shown by Riad et al. (1986) and McSweeney et al. (1988) that during $\mathrm{Na}$ deficiency this hormone responds to a decline in serum $\mathrm{Na}$ concentration and inhibits the salivary secretion of $\mathrm{Na}$ and concomitantly stimulates salivary K secretion.

The low intakes of $\mathrm{Na}$ during the depletion period caused transient changes in the plasma concentrations of $\mathrm{Na}$ and $\mathrm{K}$. It is unknown whether this observation can be generalized because, to the authors' knowledge, time-related changes of plasma $\mathrm{Na}$ and $\mathrm{K}$ concentrations during a diet-induced $\mathrm{Na}$ deficiency have not been previously reported in dairy cattle. These changes are difficult to explain but the data indicate that initial responses of plasma $\mathrm{Na}$ and $\mathrm{K}$ concentrations to $\mathrm{Na}$ deficiency are alleviated over time. It can be speculated that the initial decrease in plasma $\mathrm{Na}$ concentration is counteracted by an aldosterone-mediated action on the renal conservation of $\mathrm{Na}$ (Alan and Lingtak-Neander, 2009). Furthermore, a severe decrease in plasma $\mathrm{Na}$ concentration can be prevented for 
several months because the rumen can act as a buffer containing up to $50 \%$ of the available body $\mathrm{Na}$ (Bell, 1995). Moreover, high levels of circulating aldosterone are known to shift $\mathrm{K}$ from the extracellular to the intracellular pool (Rastegar, 1990) and enhance K secretion into the tubular lumen, thereby increasing the urinary excretion of K (Palmer and Frindt, 2000). Plasma $\mathrm{K}$ concentrations initially may have over-responded to the action of aldosterone, causing plasma $\mathrm{K}$ concentrations to decrease to critically low levels $(\sim 2.5 \mathrm{mmol} / \mathrm{L})$, as previously reported (Palmer and Frindt, 2000). Since aldosterone is the key regulator of extracellular K concentration (Suttle, 2010b), such low plasma K concentrations may have alleviated the initial aldosterone responses on the plasma $\mathrm{K}$ concentration.

The data clearly show that supplemental $\mathrm{Na}$ did not restore the salivary $\mathrm{Na} / \mathrm{K}$ to values $>6$ (Schonewille and Beynen, 2005). This was unexpected as the highest level of supplementation was calculated to exceed $(1.7 \mathrm{~g} / \mathrm{kg} \mathrm{DM})$ the dietary requirement $(1.2 \mathrm{~g} / \mathrm{kg}$ DM) (Thiangtum et al., 2011) of lactating dairy cows in a tropical environment. The actual $\mathrm{Na}$ consumed was found to be $1.6 \mathrm{~g} / \mathrm{kg} \mathrm{DM}$ for the HNa group. It thus appears that the amount of $\mathrm{Na}$ that was withdrawn from the mobilizable $\mathrm{Na}$ pool during the 3 weeks of $\mathrm{Na}$ depletion was not replenished by the supplemental Na during the 5-week repletion period. The average amount of $\mathrm{Na}$ not accounted for in milk and urine for the $\mathrm{LNa}$ and $\mathrm{HNa}$ groups during the repletion period was 8.1 and $12.4 \mathrm{~g} / \mathrm{d}$. The losses due to sweat, as well as unabsorbed dietary and endogenous fecal $\mathrm{Na}$, were not measured in the present study. Using the dietary $\mathrm{Na}$ absorption data of Thiangtum et al. (2011), it can be estimated that the apparent $\mathrm{Na}$ absorption of the $\mathrm{LNa}$ and $\mathrm{HNa}$ cows should have been approximately $85 \%$ and $87 \%$, respectively. Using these values, 2.0 and $2.4 \mathrm{~g} / \mathrm{d}$ Na would have been excreted via the feces of the cows in the $\mathrm{LNa}$ and $\mathrm{HNa}$ groups, leaving 6.1 and $9.9 \mathrm{~g} / \mathrm{d}$ unaccounted for, respectively. These amounts of $\mathrm{Na}$ would have been used by the cow to replenish the mobilizable Na pool of the rumen and sweat production. During the 3 weeks of Na depletion, a total amount of $44 \mathrm{~g}$ Na was minimally withdrawn from the animal's mobilizable Na pool.

Throughout the 56-day experiment, the cows experienced, on average, $4 \mathrm{~h}$ of mild (THI 72-79), $19 \mathrm{~h}$ of moderate (THI 79-89) and $1 \mathrm{~h}$ of severe (THI > 89) heat stress (Armstrong, 1994; Akyuz et al., 2010) each 24 h. Jenkinson and Mabon (1973) reported that $\mathrm{Na}$ losses with sweat ranged from 7.1 to $10 \mathrm{mg} / \mathrm{m}^{2} / \mathrm{h}$ when THI ranged from 79 to 81 . Gebremedhin et al. (2011) reported sweating rates in Holstein cows of up to $660 \mathrm{~g} / \mathrm{m}^{2} / \mathrm{h}$ at a THI of 79.6. When a sweating rate of $600 \mathrm{~g} / \mathrm{m}^{2} / \mathrm{h}$ is used and an estimated surface area of 4.5 $\mathrm{m}^{2}$ (BW $433 \mathrm{~kg}$ ) (Brody, 1945), the Na concentration of sweat under the current conditions were maximally $6.6 \mathrm{mmol} \mathrm{Na} / \mathrm{kg}$, assuming the aforementioned apparent $\mathrm{Na}$ absorption and 
no replenishment of the mobilizable Na pool of the rumen. In the case of replenishment of the rumen pool, the $\mathrm{Na}$ concentration of sweat was $5.8 \mathrm{mmol} \mathrm{Na} / \mathrm{kg}$. The latter two values are much higher than the value of $2 \mathrm{mmol} \mathrm{Na} / \mathrm{kg}$ sweat reported by Johnson (1970). Clearly, there is a considerable discrepancy between the $\mathrm{Na}$ losses with sweat calculated here and the data provided by Jenkinson and Mabon (1973) which cannot easily be explained. The issue on $\mathrm{Na}$ losses with sweat in cattle remains and requires further research to obtain accurate values. The lack of unequivocal estimates on the $\mathrm{Na}$ losses with sweat, in combination with the fact that the Na-supplemented cows did not restore their salivary $\mathrm{Na}$ and $\mathrm{K}$ concentrations, hinders potential refinement of the previous recommendation regarding the $\mathrm{Na}$ requirement of lactating cows under tropical conditions (Thiangtum et al., 2011).

Across dietary $\mathrm{Na}$ intake and time, cows ingested $128.0 \mathrm{~g} \mathrm{~K} / \mathrm{d}$. Using the average dietary K absorption data (93.0\%) of Thiangtum et al. (2011), it can be estimated that the apparent $\mathrm{K}$ excretion with feces was $9.0 \mathrm{~g} / \mathrm{d}$. The associated $\mathrm{K}$ excretions with milk and urine were found to be 23.1 and $72.4 \mathrm{~g} / \mathrm{d}$. Consequently, $23.5 \mathrm{~g} / \mathrm{d}$ of $\mathrm{K}$ was available for excretion with sweat. Using the data on $\mathrm{K}$ excretion with sweat reported by Jenkinson and Mabon (1973) and the aforementioned values of surface area and time of exposure to heat stress, K excretion with sweat is estimated to be $\sim 2 \mathrm{~g} / \mathrm{d}$. Therefore, it can be excluded that the animals suffered from $\mathrm{K}$ deficiency in the current experiment, corroborated by the lack of clinical signs of K deficiency such as muscular weakness, stiffness and paralysis (Suttle, 2010b).

\section{ACKNOWLEDGEMENTS}

The authors gratefully thank the staff and students of the Faculty of Veterinary Medicine, Kasetsart University, for their contribution on sample collection and chemical analysis. The project was financially supported by Intervet (Thailand) Ltd.

\section{REFERENCES}

Agricultural Research Council (ARC). 1980. The Nutrient Requirements of Ruminant Livestock. CAB, Farnham Royal, UK.

Akyuz, A., S. Boyaci and A. Cayli. 2010. Determination of critical period for dairy cows using temperature humidity index. J. Anim. Vet. Adv. 9:1824-1827.

Alan, L. and C. Lingtak-Neander. 2009. Electrolytes, other minerals, and trace elements, in Basic Skills in Interpreting Laboratory Data (4th edn). American Society of HealthSystem Pharmacists, Bethesda, MD, pp. 119-131. 
Armstrong, D. V. 1994. Heat stress interaction with shade and cooling. J. Dairy Sci. 77:20442050 .

Association of Official Analytical Chemists (AOAC). 1990. Official Methods of Analysis. Washington, DC.

Bell, F. R. 1995. Perception of sodium and sodium appetite in farm animals, in Sodium in Agriculture, ed. by Phillip C. J. C. and P. C. Chiy. Chalcombe Publications, UK, pp. $82-90$.

Blair-West, J. R., D. A. Denton, M. J. McKinley and R. S. Weisinger. 1988. Angiotensinrelated sodium appetite and thirst in cattle. Am. J. Physiol. 255:R205-R211.

Blair-West J. R., J. P. Coghlan, D. A. Denton, J. R. Goding and R. D. Wright. 1963. The effect of aldosterone, cortisol, and corticosterone upon the sodium and potassium content of sheep's parotid saliva. J. Clin. Invest. 42:484-496.

Brody, S. 1945. Bioenergetics and Growth: With Special Reference to the Energetic Efficiency Complex in Domestic Animals, Reinhold, New York, pp. 354-403.

Central Bureau for Livestock Feeding (CVB). 2005. Handleiding Mineralenvoorziening Rundvee, Schapen, Geiten. (Manual for Mineral Supply Cattle, Sheep, Goats). CVB, Lelystad, Netherlands.

DLG. 2001. Ausschuss für Bedarfsnormen der Gesellschaft für Ernährungsphysiologie; Energie-und Nährstoffbedarf Landwirtschaftlicher Nutztiere. DLG-verlag Nr.8. Empfehlungen zur Energie-und Nährstoffversorgung der Milchkühe und Aufzuchtsrinder. DLG-verlag, Frankfurt, pp. 71-88.

Gebremedhin, K. G., C. N. Lee, P. E. Hillman and R. J. Collier. 2011.Physiological responses of dairy cows during extended solar exposure. Transactions of the ASABE 53:239247.

Gueguen, L., M. Lamand and F. Meschy. 1989. Mineral requirements, in Ruminant Nutrition: Recommended Allowance and Feed Tables, ed. by Jarrige R. INRA/John Libbey, Paris, pp. 49-59

Houpt, T. R. 1993. Water and electrolytes, in Dukes's Physiology of Domestic Animals (11th edn), ed. by Swenson M. J. and W. O. Reece. Cornell University Press, Ithaca, NY, pp. 9-21.

Jenkinson, D. M. and R. M. Mabon. 1973. The effect of temperature and humidity on skin surface $\mathrm{pH}$ and the ionic composition of skin secretions in Ayrshire cattle. Br. Vet. J. 129:282-295. 
Johnson, K. G. 1970. Sweating rate and the electrolyte content of skin secretions of Bos taurus and Bos indicus cross-bred cows. J. Agric. Sci. 75:395-402.

McSweeney, C. S., R. B. Cross, B. T. Wholohan and M. R. Murphy. 1988. Diagnosis of sodium status in small ruminants. Aust. J. Agric. Res. 39:935-942.

National Research Council (NRC). 1971. A Guide to Environmental Research on Animals. National Academy of Science, Washington, DC.

National Research Council (NRC). 2001. Nutrient Requirements of Dairy Cattle (7th rev. edn) National Academy Press, Washington, DC.

Palmer, L. G. and G. Frindt. 2000. Aldosterone and potassium secretion by the cortical collecting duct. Kidney Int. 57:1324-1328.

Rastegar, A. 1990. Serum potassium, in Clinical Methods: The History, Physical, and Laboratory Examinations (3rd edn), ed. by Walker H. K., W. D. Hall and J. W. Hurst. Butterworth, Boston, pp. 884-887.

Riad, F., J. Lefaivre, C. Tournaire and J. P. Barlet. 1986. Aldosterone regulates salivary sodium secretion in cattle. J. Endocr. 108:405-411.

Sanchez, W. K., M. A. McGuire and D. K. Beede. 1994. Macromineral nutrition by heat stress interactions in dairy cattle: review and original research. J. Dairy Sci. 77:20152079.

Schneider, P. L., D. K. Beede and C. J. Wilcox. 1986. Responses of lactating cows to dietary sodium source and quantity and potassium quantity during heat stress. J. Dairy Sci. 69:99-110.

Schonewille, J. T. and A. C. Beynen. 2005. Reviews on the mineral provision in ruminants (IV): Sodium metabolism and requirements in ruminants, in CVB Documentation Report Nr 36. Central Bureau for Livestock Feeding.

Suttle, N. F. 2010a. Sodium and chloride, in The Mineral Nutrition of Livestock (4th edn), ed. by Suttle N. F. CABI, London, pp. 182-205.

Suttle, N. F. 2010b. Potassium, in The Mineral Nutrition of Livestock (4th edn), ed. by Suttle N. F. CABI, London, pp. 168-181.

Thiangtum, W., A. Yawongsa, J. T. Schonewille, T. Rukkwamsuk, C. Yuangklang, M. W. A. Verstegen and W. H. Hendriks. 2011. An attempt to define the sodium requirement of lactating dairy cows in a tropical environment. J. Sci. Food Agric. 91:2333-2337.

Whitlock, R. H., M. J. Kessler and J. B. Tasker. 1975. Salt (sodium) deficiency in dairy cattle: polyuria and polydipsia as prominent clinical features. Cornell Vet. 65:512-526. 
Van Soest, P. J., J. B. Robertson and B. A. Lewis. 1991. Methods for dietary fiber, neutral detergent fiber, and nonstarch polysaccharides in relation to animal nutrition. J. Dairy Sci. 74:3583-3597. 


\section{Chapter 5}

\section{Effect of Dietary Protein Levels on Rumen Metabolism and Milk Yield in Mid-Lactating Cows under Hot and Humid Conditions}

Wandee Thiangtum $^{1,4}$, J Thomas Schonewille ${ }^{2,3}$, Adisorn Yawongsa ${ }^{1}$, Theera Rukkwamsuk ${ }^{1}$, Jeerachai Kanjanapruthipong ${ }^{3}$, Martin WA Verstegen ${ }^{4}$ and Wouter H Hendriks ${ }^{2,4}$

\footnotetext{
${ }^{1}$ Department of Large Animal and Wildlife Clinical Sciences, Faculty of Veterinary Medicine, Kasetsart University, Thailand

${ }^{2}$ Department of Farm Animal Health, Faculty of Veterinary Medicine, Utrecht University, The Netherland

${ }^{3}$ Department of Animal Sciences, Faculty of Agriculture Kamphaengsaen, Kasetsart University, Thailand

${ }^{4}$ Department of Animal Sciences, Wageningen University, The Netherlands
}

Journal of Animal and Veterinary Advances (2014) 13:9-14 


\begin{abstract}
An experiment was conducted to investigate the effects of 2 levels of dietary Crude Protein (CP) in concentrates with similar proportions of Rumen Undegradable Protein (RUP) on rumen metabolism, milk yield and composition in mid lactating cows in Thailand. Eight $87.5 \%$ Holstein $\times 12.5 \%$ indigenous multiparous cows were used in a crossover design with two successive 25 day periods. Diets contained 30\% paragrass and 70\% concentrate on a Dry Matter (DM) basis. Concentrate feeds were formulated to provide low dietary CP [17.3\%; LCP] or high dietary CP [19.0\%; HCP]. The proportion of Rumen Degradable Protein (RDP) and RUP was $61 \%$ and $39 \%$ in both diets. Diets were isocaloric in terms of net energy for lactation. Milk yield, milk lactose yield, Dry Matter Intake (DMI), and apparent digestibility of DM, CP and Neutral Detergent Fibre (NDF) were greater in cows fed HCP than in those fed LCP. Concentration of blood urea nitrogen was elevated in cows fed HCP diets. Rumen $\mathrm{NH}_{3}-\mathrm{N}$ concentration and $\mathrm{pH}$ tended to increase in cows fed HCP diet. Rumen microorganism counts and volatile fatty acids levels in the rumen did not differ between treatments. The increasing CP content in mid-lactating cow was beneficial to increase DMI, apparent digestibility of DM, CP and NDF and therefore milk yield.
\end{abstract}




\section{INTRODUCTION}

The majority of forage in the tropics is low in digestibility and nutrient contents and thus limits feed intake and milk output in ruminants (Camero et al., 2001; Leng, 1990). Consequently, lactating Thai dairy cows mostly ingest poor quality roughage. Therefore, it is common practice in Thailand to reduce the relative amount of roughage, while increasing the proportion of concentrate in order to increase nutrient supply to the animals (Kanjanapruthipong et al., 2001). The protein level of the concentrates is important to ensure an adequate supply of dietary protein in supporting milk production in the tropics because of low Crude Protein (CP) content in typical tropical roughage (Korhonen et al., 2002).

Providing sufficient protein to dairy cows depends on the balance between the availability of nitrogen for microbial growth in the rumen and nitrogen for productive functions (Ferguson et al., 1988). At the same intake of dietary protein, a shortage of Rumen Degradable Protein (RDP) may reduce microbial growth in the rumen. Consequently, rumen digestibility (Chalupa, 1984), Dry Matter Intake (DMI) (Weigel et al., 1997) and microbial protein synthesis and thus protein flow from the rumen (Argyle and Baldwin, 1989) may be reduced. Nowadays there is a tendency towards an increase of dietary protein supply above NRC requirements (NRC, 2001) to optimize the production of dairy cows under hot and humid climates. However, experimental data that corroborate this tendency are scarce. Therefore, the aim of the present study was to investigate the effect of 2 levels of dietary CP with equal proportions of rumen RDP and RUP on digestion, rumen metabolism, blood urea nitrogen, milk yield and milk composition in mid-lactating cows.

\section{MATERIALS AND METHODS}

\section{Animals and feeding}

Eight Holstein $\times$ indigenous $(87.5 \times 12.5)$ multiparous dairy cows with $113 \pm 12$ Days in Milk (DIM) and weighing $469 \pm 46 \mathrm{~kg}$ were used. The parity of the cows ranged from 2-5 and the mean was $3( \pm 1.3)$.

The trial had a $25 \times 25$ days cross over design with a 16 days wash out period (Cochran and Cox, 1957). Data were collected from day 17-25 of each experimental period. The animals were randomly assigned to the two treatments, i.e. a low protein (17\%, LCP) and a high protein $(19 \%, \mathrm{HCP})$ concentrate. The proportions of RDP and RUP were similar for both concentrates; i.e. 61 and 39\%, respectively. The energy density was the same for both 
experimental concentrates (1.7 Mcal $\left.\mathrm{NE}_{\mathrm{L}} / \mathrm{kg} \mathrm{DM}\right)$. Each day, the cows were first fed with concentrates at a level of $2.1 \%$ of Body Weight (BW) in DM and then fed paragrass (Brachiaria mutica) at a level of $0.9 \%$ of BW in DM. Each feed was offered 3 times per day at 08:00, 14:00, and 21:00 h. Paragrass was harvested at a 45-50 day interval. Individual feed intakes and refusals were recorded daily.

Table 1. Ingredient composition of the experimental concentrates

\begin{tabular}{lcc}
\hline Ingredients (\%) & LCP $^{\mathrm{a}}$ & HCP \\
\hline Full fat soybean & 7.1 & 11.5 \\
Cassava chip & 30.9 & 23.4 \\
Palm kernel cake & 11.5 & 12.0 \\
Soybean meal & 1.0 & 6.0 \\
Kapok seed meal & 13.4 & 12.0 \\
Whole cotton seed & 10.0 & 10.0 \\
Coconut meal & 16.0 & 15.0 \\
Molasses, sugarcane & 5.5 & 5.5 \\
Urea & 0.6 & 0.6 \\
Mono dicalcium phosphate & 1.0 & 1.0 \\
Sodium bicarbonate & 1.5 & 1.5 \\
Sulphur & 0.3 & 0.3 \\
Magnesium oxide & 0.2 & 0.2 \\
Trace mineral and vitamin mix & 0.5 & 0.5 \\
NaCl & 0.5 & 0.5
\end{tabular}

${ }^{\mathrm{a}} \mathrm{LCP}$, concentrate containing a low $\mathrm{CP}$ content; HCP, concentrate containing a high CP content.

${ }^{\mathrm{b}}$ Consists of (per kg) 2 million IU of vitamin A; 0.40 million IU of vitamin D3; 3,000 IU of vitamin E; $0.46 \mathrm{~g}$ of vitamin $\mathrm{K} ; 10.0 \mathrm{~g}$ of Fe; $4.0 \mathrm{~g}$ of $\mathrm{Cu} ; 7.4 \mathrm{~g}$ of $\mathrm{Mn} ; 0.20 \mathrm{~g}$ of $\mathrm{Co} ; 15.0 \mathrm{~g}$ of $\mathrm{Zn} ; 0.20 \mathrm{~g}$ of $\mathrm{I}$ and $0.08 \mathrm{~g}$ of Se.

Concentrate ingredients and the chemical composition of the feedstuffs are given in Tables 1 and 2, respectively. Cows were housed in tied-stalls with individual feed bins. Animals had free access to water. Cows were milked by a milking machine twice daily at 06:00 and 15:30 h. The experiment was conducted in the months of January and February with mean minimum and maximum temperatures at $21.3 \pm 2.4$ and $33.1 \pm 2.5{ }^{\circ} \mathrm{C}$, respectively. Mean maximum and minimum relative humidity was $96.1 \pm 1.1$ and $48.6 \pm 10.0 \%$, respectively. The average maximum and minimum Temperature Humidity Index (THI) was 
$90.9 \pm 4.2$ and $66.9 \pm 3.3$, respectively. The climatic conditions during the study are shown in Figure 1.

Table 2. Chemical composition of the experimental concentrates and grass

\begin{tabular}{|c|c|c|c|}
\hline Chemical analysis (\% DM) & $\mathrm{LCP}^{\mathrm{a}}$ & $\mathrm{HCP}$ & Grass \\
\hline Crude protein & 17.30 & 19.05 & 10.67 \\
\hline Rumen undegradable protein ${ }^{\mathrm{b}}$ & 6.90 & 7.33 & 1.28 \\
\hline NDF & 52.75 & 51.38 & 75.94 \\
\hline $\mathrm{ADF}$ & 19.06 & 17.75 & 39.20 \\
\hline Ether extract & 8.79 & 9.45 & 1.09 \\
\hline Ash & 12.16 & 12.41 & 13.05 \\
\hline AIA & 0.78 & 0.60 & 7.16 \\
\hline $\mathrm{NE}_{\mathrm{L}}(\mathrm{Mcal} / \mathrm{kg} \mathrm{DM})$ & $1.68^{\mathrm{c}}$ & $1.71^{\mathrm{c}}$ & $1.30^{\mathrm{d}}$ \\
\hline TDN & 73.47 & 74.67 & 57.84 \\
\hline
\end{tabular}

${ }^{\mathrm{a}} \mathrm{LCP}$, concentrate containing a low $\mathrm{CP}$ content; HCP, concentrate containing a high $\mathrm{CP}$ content.

${ }^{\mathrm{b}}$ Calculated RUP and TDN based on nutrient compositions of Thai feed table (Angthong et al., 2004; Kanjanapruthipong, 2006; Moran, 2005).

${ }^{\mathrm{c}} \mathrm{NE}_{\mathrm{L}}(\mathrm{Mcal} / \mathrm{kgDM})=0.0245 * \mathrm{TDN}(\%)-0.12(\mathrm{NRC}, 1989)$.

${ }^{\mathrm{d}} \mathrm{NE}_{\mathrm{L}}(\mathrm{Mcal} / \mathrm{kgDM})=2.3977-(0.0280 * \mathrm{ADF} \%)($ Ishler et al., 1996).

\section{Sampling and chemical analyses}

Cows were weighed on the first and again on the final day of both periods before morning feeding. Milk yields were recorded from days 16-24 in each experimental period. Milk samples (approximately $30 \mathrm{~mL}$ per milking) were collected during days 22, 23 and 24 at each of the two milkings. Milk samples were placed in bottles containing $0.02 \%$ of 2-bromo-2nitro-1,3-propanediol and stored at $5{ }^{\circ} \mathrm{C}$ until determination of milk composition (fat, protein, lactose and non fat solids) by infrared spectroscopy (Bentley 2000, Agriyork Ltd.,UK). Concentrates and grass were sampled once a week, to determine DM content. The weekly samples were dried at $60{ }^{\circ} \mathrm{C}$ and were pooled based on $\mathrm{CP}$ content per period. The pooled samples were analysed for crude protein, ether extract (EE) and ash according to the Association of Official Analytical Chemists (AOAC, 1990) procedure and Neutral Detergent Fibre (NDF) and Acid Detergent Fibre (ADF) following the method by Van Soest et al. (1991). 


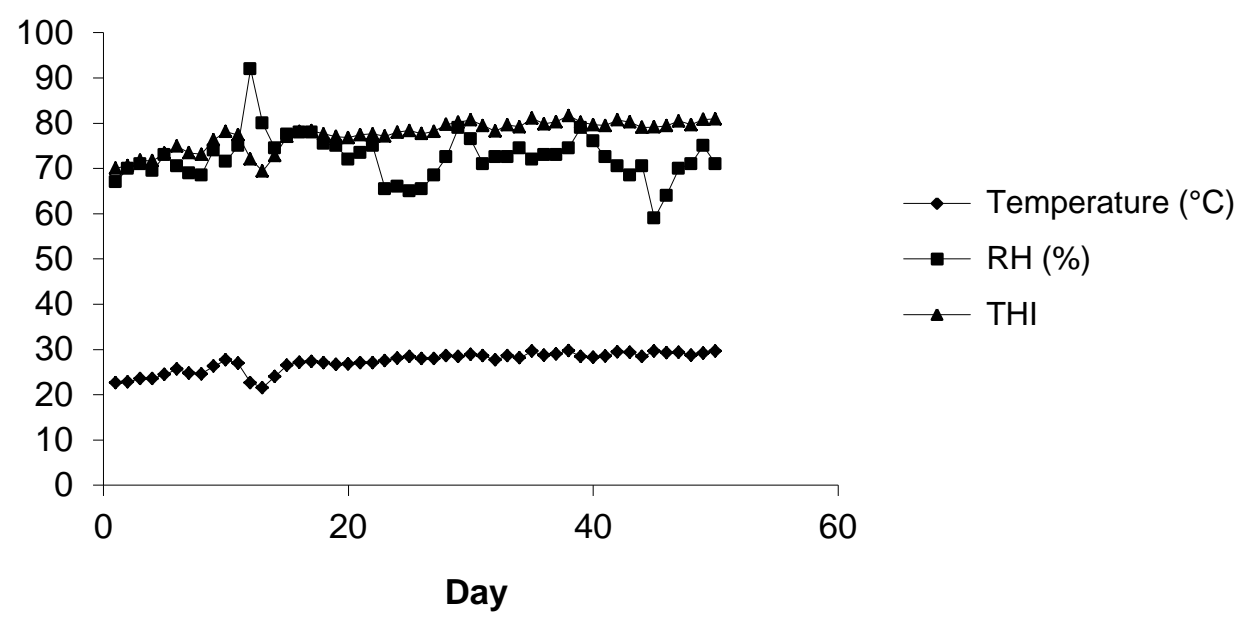

Figure 1. The average temperature $\left({ }^{\circ} \mathrm{C}\right)$, relative humidity $(\mathrm{RH}, \%)$ and temperature humidity index (THI) during the experimental periods.

Blood samples, $10 \mathrm{~mL}$ were collected from the jugular vein of each cow at days 23 and day 24 of each period at $4 \mathrm{~h}$ after morning feeding. Then, blood samples were centrifuged for $5 \mathrm{~min}$ at $500 \mathrm{~g}$. All serum samples were stored at $-20{ }^{\circ} \mathrm{C}$ until analysis for Blood Urea Nitrogen (BUN) concentration by spectrophotometry (Urease-Berthelot).

Faecal samples from each cow were collected after the morning feeding on the last day of each period. They were dried in a $60{ }^{\circ} \mathrm{C}$ forced-air oven and ground in a Wiley mill to pass through a 1-mm screen. Samples were subsequently analysed for NDF, CP and Acid Insoluble Ash (AIA). The AIA was used as an internal marker to determine apparent totaltract DM digestibility (Van Keulen et al., 1977).

Rumen fluids were collected by means of a nasogastric tube on day 25 of each period. Whole ruminal contents (100-200 mL) were taken $4 \mathrm{~h}$ after the morning feeding. Rumen fluid $\mathrm{pH}$ was measured immediately by using $\mathrm{pH}$ meter (EC 20, HACH, USA). The rest of rumen fluid was strained through four layers of cheesecloth. Two sub-samples were taken from the strained fluid: one $10 \mathrm{~mL}$ sample was preserved by the addition of $1 \mathrm{~mL}$ of $50 \%$ (vol./vol.) $\mathrm{H}_{2} \mathrm{SO}_{4}$ for later analysis of ammonia $\left(\mathrm{NH}_{3}-\mathrm{N}\right)$ and Volatile Fatty Acids (VFAs) and one $9 \mathrm{~mL}$ sample was preserved by the addition of $1 \mathrm{~mL}$ of $10 \%$ formalin solution for later analysis of total direct count of bacteria, protozoa and zoospores (Galyean, 1989). All ruminal samples were stored at $-20^{\circ} \mathrm{C}$. Just before analysis, samples were thawed, centrifuged $(15000 \times g$ for $15 \mathrm{~min}$ ), and analysed for $\mathrm{NH}_{3}-\mathrm{N}$ concentration (Bremner and Keeney, 1965) and for VFAs by gas chromatography following the method modified from Erwin et al. (1961). 


\section{Statistical analysis}

Milk yield, milk composition, DM intake, digestibility, $\mathrm{BUN}$, ruminal $\mathrm{pH}, \mathrm{NH}_{3}-\mathrm{N}$, VFAs and microbial counts were subjected to ANOVA (SAS, 2001). Experimental period (fixed) and dietary treatment were factors (SAS, 2001). Effects were considered significant at $P \leq 0.05$.

Table 3. Intake of DM and selected nutrients and digestibilities of DM, CP and NDF in cows fed either the low (LCP) or the high CP (HCP) concentrates

\begin{tabular}{|c|c|c|c|c|}
\hline \multirow[t]{2}{*}{ Contents } & \multicolumn{2}{|c|}{ Diets } & \multirow[t]{2}{*}{ SEM $^{\mathrm{a}}$} & \multirow[t]{2}{*}{$P$ value } \\
\hline & LCP & $\mathrm{HCP}$ & & \\
\hline \multicolumn{5}{|l|}{ Intake } \\
\hline Total DMI (kg/d) & 11.71 & 12.24 & 0.37 & 0.01 \\
\hline Concentrate DMI $(\mathrm{kg} / \mathrm{d})$ & 8.41 & 8.77 & 0.35 & 0.10 \\
\hline Paragrass DMI (kg/d) & 3.30 & 3.48 & 0.13 & 0.04 \\
\hline $\mathrm{CP}$ intake $(\mathrm{kg} / \mathrm{d})$ & 1.81 & 2.04 & 0.09 & $<0.01$ \\
\hline CP intake $(\%)$ & 15.43 & 16.63 & 0.18 & $<0.01$ \\
\hline RUP intake (kg/d) & 0.63 & 0.69 & 0.03 & 0.01 \\
\hline RDP intake (kg/d) & 1.18 & 1.35 & 0.05 & $<0.01$ \\
\hline $\mathrm{NE}_{\mathrm{L}}$ intake $(\mathrm{Mcal} / \mathrm{d})$ & 18.41 & 19.42 & 0.61 & $<0.01$ \\
\hline EE intake (kg/d) & 0.78 & 0.81 & 0.03 & 0.09 \\
\hline NDF intake (kg/d) & 6.94 & 7.16 & 0.20 & 0.03 \\
\hline \multicolumn{5}{|l|}{ Digestibility (\%) } \\
\hline Dry matter & 54.88 & 63.06 & 2.70 & $<0.01$ \\
\hline $\mathrm{CP}$ & 63.80 & 72.22 & 1.84 & $<0.01$ \\
\hline NDF & 61.76 & 69.02 & 2.47 & $<0.01$ \\
\hline
\end{tabular}

${ }^{\mathrm{a}}$ Standard error of the mean.

\section{RESULTS}

\section{Body weight, nutrient intake and digestibility}

Body weight was not affected by dietary treatments. Mean BW at the end of the experiment was $468 \mathrm{~kg}(\mathrm{SE}=13.8 ; \mathrm{n}=8)$, which is similar to pre-experimental values $(P>0.1)$. Nutrient intake and digestibilities of DM, CP and NDF are shown in Table 3. Total DM intake was $0.53 \mathrm{~kg} / \mathrm{d}$ higher in cows fed HCP diet than in those fed the LCP diet which was mainly caused by the difference in concentrate intake. However, in contrast with the difference in 
grass intake between the two experimental diets, the difference in concentrate intake appeared to be non-significant. The intakes of $\mathrm{CP}, \mathrm{RUP}, \mathrm{RDP}, \mathrm{NDF}$ and $\mathrm{NE}_{\mathrm{L}}$ were significantly increased when the cows were fed the HCP diet. Digestibilities of DM, CP and NDF were influenced by dietary treatments. Cows that were fed the LCP diet had significantly lower digestibilities of DM, CP and NDF.

Table 4. Lactational performance of cows fed either the low (LCP) or the high CP (HCP) concentrates

\begin{tabular}{|c|c|c|c|c|}
\hline \multirow[t]{2}{*}{ Contents } & \multicolumn{2}{|c|}{ Diets } & \multirow[t]{2}{*}{$\mathrm{SEM}^{\mathrm{a}}$} & \multirow[t]{2}{*}{$P$ value } \\
\hline & LCP & $\mathrm{HCP}$ & & \\
\hline \multicolumn{5}{|l|}{ Milk production } \\
\hline Milk yield (kg/d) & 12.28 & 13.31 & 0.65 & $<0.01$ \\
\hline $3.5 \%$ FCM yield $(\mathrm{kg} / \mathrm{d})$ & 12.90 & 13.65 & 0.79 & 0.24 \\
\hline Fat yield (kg/d) & 0.47 & 0.49 & 0.03 & 0.50 \\
\hline Protein yield (kg/d) & 0.36 & 0.38 & 0.02 & 0.21 \\
\hline Lactose yield (kg/d) & 0.57 & 0.62 & 0.04 & 0.01 \\
\hline \multicolumn{5}{|l|}{ Milk composition } \\
\hline Milk fat (\%) & 3.81 & 3.66 & 0.19 & 0.37 \\
\hline Milk protein $(\%)$ & 2.94 & 2.85 & 0.06 & 0.22 \\
\hline Milk lactose (\%) & 4.57 & 4.62 & 0.07 & 0.18 \\
\hline Solid not fat (\%) & 8.17 & 8.13 & 0.13 & 0.53 \\
\hline
\end{tabular}

${ }^{\mathrm{a}}$ Standard error of the mean.

\section{Milk production}

Effects of dietary treatments on milk production are shown in Table 4. Cows fed the LCP diet had a significantly lower milk yield and lactose yield than those fed the HCP diet. The amount of $3.5 \%$ fat corrected milk and the contents of fat, protein, lactose, and non-fat solids in milk were similar on both CP treatments. 
Table 5. Selected indices of rumen fermentation, blood urea nitrogen (BUN) and rumen microorganisms of cows fed either the low (LCP) or the high $\mathrm{CP}(\mathrm{HCP})$ concentrates

\begin{tabular}{|c|c|c|c|c|}
\hline \multirow[t]{2}{*}{ Contents } & \multicolumn{2}{|c|}{ Diets } & \multirow[t]{2}{*}{$\mathrm{SEM}^{\mathrm{a}}$} & \multirow[t]{2}{*}{$P$ value } \\
\hline & $\mathrm{LCP}$ & $\mathrm{HCP}$ & & \\
\hline \multicolumn{5}{|l|}{ Ruminal metabolism } \\
\hline $\mathrm{pH}$ & 6.22 & 6.29 & 0.04 & 0.21 \\
\hline $\mathrm{NH}_{3}-\mathrm{N}(\mathrm{mg} \%)$ & 24.31 & 28.28 & 1.46 & 0.11 \\
\hline Acetate $(\%)$ & 65.77 & 65.75 & 1.01 & 0.98 \\
\hline Propionate $(\%)$ & 23.37 & 22.73 & 1.16 & 0.68 \\
\hline Butyrate (\%) & 10.23 & 10.85 & 0.43 & 0.24 \\
\hline Valerate $(\%)$ & 0.63 & 0.66 & 0.06 & 0.67 \\
\hline Total VFA (mmol/L) & 138.47 & 141.81 & 5.02 & 0.82 \\
\hline $\mathrm{A} / \mathrm{P}^{\mathrm{b}}$ & 3.04 & 2.95 & 0.20 & 0.74 \\
\hline BUN (mg/dL) & 12.23 & 14.73 & 0.70 & 0.01 \\
\hline \multicolumn{5}{|l|}{ Rumen microorganisms } \\
\hline Bacteria $\left(10^{11}\right.$ cell $\left./ \mathrm{mL}\right)$ & 2.20 & 2.16 & 0.17 & 0.88 \\
\hline Protozoa $\left(10^{5}\right.$ cell $\left./ \mathrm{mL}\right)$ & 5.81 & 3.78 & 0.64 & 0.09 \\
\hline Zoospore $\left(10^{5}\right.$ cell $\left./ \mathrm{mL}\right)$ & 1.69 & 1.48 & 0.13 & 0.42 \\
\hline
\end{tabular}

${ }^{a}$ Standard error of the mean.

${ }^{\mathrm{b}} \mathrm{A} / \mathrm{P}$, Acetate/Propionate ratio.

\section{Rumen metabolism and blood urea nitrogen}

Effects of dietary treatments on selected indices on rumen metabolism and BUN are presented in Table 5. Rumen $\mathrm{NH}_{3}-\mathrm{N}$ concentrations and rumen $\mathrm{pH}$ were similar between experimental treatments. However, rumen $\mathrm{NH}_{3}-\mathrm{N}$ concentrations and $\mathrm{pH}$ had a tendency to increase when the cows were fed the HCP diet. Mean BUN concentrations were significantly higher in cows fed the HCP diet. The profile of individual VFAs in the rumen and the acetate to propionate ratio did not show clear differences between the two experimental treatments. Furthermore, bacteria, protozoa and zoospore counts in the rumen content of the cows were similar for both dietary treatments. 


\section{DISCUSSION}

\section{Dry matter intake and digestibility}

In this experiment, the mean Temperature Humidity Index (THI) was 77, which is above the upper point of 72 for optimal dairy cow productivity (Ravagnolo et al., 2000). The THI in the current study indicated that the cows experienced mild heat stress (THI 72 to 78) (Armstrong, 1994). Feed intake in cows with heat stress may be reduced by $8 \%$ or more, thereby negatively affecting milk production (Kabuga, 1990). In the current study, feed intake was lower than the NRC (2001) estimation for these cows; i.e. 14 and 11\% lower for the LCP and HCP treatment respectively. However, NRC (2001) estimations of feed intake are based on temperate climatological conditions, it may be suggested that the climatological condition during the current experiment was at least partly, responsible for the relative low level of feed intake. The lower DMI was likely to reflect the poor quality of roughage in tropical regions (Leng, 1990). During heat stress, cows reduce feed intake in particular with high fibre diets (Kanjanapruthipong et al., 2010). In contrast, the present study showed that roughage intake was greater in cows fed HCP diet than those fed LCP. This high DMI for cows fed HCP diet can be explained in part by differences in apparent DM, CP and NDF digestibility between diets. This is in agreement with other studies (Blauwiekel and Kincaid, 1986; Jones-Endsley et al., 1997).

In the current study, DM, CP and NDF digestibility were increased by 15,13 and $12 \%$, respectively when the HCP diet was fed. This observation is corroborated by Tyrrell et al. (1981), Weigel et al. (1997) and Kendall et al. (2009) who observed an increased nutrient digestibility when the dietary $\mathrm{CP}$ content was raised from 11 to about 18\% (DM basis). Concentration of rumen microbial yield did not differ between cows on HCP and LCP. This result on digestibility was in agreement with earlier reports in sheep that the increasing levels of concentrate in the diet resulted in increased total tract apparent digestibility of DM, organic matter and CP and similar microbial population (Ramos et al., 2009).

\section{Milk production and milk composition}

An increase in dietary CP intake may affect milk yield by increasing the availability of $\mathrm{NH}_{3}$, peptides and amino acids for microbial growth in the rumen (Bequette et al., 1998). Providing adequate protein to dairy cows increases milk production under tropical conditions (Promma et al., 2002). Supplementing diets with CP increased DMI and as a consequence 
also milk yield (Reynal and Broderick, 2003). Similar results were observed in the present study, cows on the diet containing HCP produced more milk than those fed the LCP diet. The responses of milk yield agree with higher intakes of $\mathrm{NE}_{\mathrm{L}}(+2.12 \mathrm{Mcal})$ and $\mathrm{CP}(+220 \mathrm{~g})$ intake than recommended by the NRC (2001). Promma et al., (2002) suggested that for dairy cows in tropical ambient conditions the energy and CP intake should be $20 \%$ higher than the NRC recommendation for dairy cows in moderate climatic condition. Similarly, Kalscheur et al. (2006) showed that cows fed a high RDP supplement (11\% RDP, 17\% CP) produced more milk yield than cows on a low RDP supplement diet (8.2\% RDP, $14 \% \mathrm{CP})$. In contrast, supplemental CP at a higher level did not affect milk composition in the current study. This observation is in line with the results reported by Reynal and Broderick (2003) and Mulligan et al. (2004).

\section{Rumen metabolism and blood urea nitrogen}

When CP intake exceeds the requirements for microbial growth or when there is an insufficient supply of fermentable carbohydrates for microbial growth, there is a potential for nitrogen $(\mathrm{N})$ loss from $\mathrm{N}$ surplus in the form of ammonia (Agle et al., 2010; Kim et al., 2000). In this study, rumen $\mathrm{NH}_{3}-\mathrm{N}$ concentration $(P=0.1)$ tended to increase in cows fed $\mathrm{HCP}$ diet. However, these rumen $\mathrm{NH}_{3}-\mathrm{N}$ concentrations $(24.31-28.28 \mathrm{mg} / \mathrm{dL})$ were in line with results of earlier studies indicating that the optimum rumen $\mathrm{NH}_{3}-\mathrm{N}$ should be between 10-30 mg/dL for rumen fermentation on low-quality roughage (Chanjula 2004; Khampa and Wanapat, 2006). As a consequence of increased rumen $\mathrm{NH}_{3}-\mathrm{N}, \mathrm{NH}_{3}-\mathrm{N}$ will be converted to urea. In general there is a positive correlation between rumen $\mathrm{NH}_{3}-\mathrm{N}$ and $\mathrm{BUN}$ concentration (Odensten et al. 2005; Ropstad et al. 1989). The current study also showed that BUN in cows fed HCP diet was higher than those fed LCP diet. However, BUN concentration in cows fed HCP diet was still in the normal range. The optimal BUN concentration ranges from 12-17 $\mathrm{mg} / \mathrm{dL}$ according to Baker et al. (1995).

It can be concluded that DMI and therefore milk production in mid-lactation cows under hot and humid conditions could be increased by increasing $\mathrm{CP}$ content higher than the CP level recommended by NRC (2001). 


\section{ACKNOWLEDGEMENTS}

Reseachers gratefully thank the staff of both the research farm of the Faculty of Veterinary Medicine, Kasetsart University (Thailand) for allowing us to perform the current study and the Ratchaburi Artificial Insemination and Biotechnology Research Center for milk analysis. Financial support was provided by Intervet (Thailand) Ltd. and the Faculty of Veterinary Medicine, Kasetsart University.

\section{REFERENCES}

Agle, M., A. N. Hristov, S. Zaman, C. Schneider, P. Ndegwa and V. K. Vaddella. 2010. The effect of ruminally degraded protein on rumen fermentation and ammonia losses from manure in dairy cows. J. Dairy Sci. 93:1625-1637.

Angthong, W., S. Pongpiajan and W. Panichpol. 2004. Table of nutritive values of animal feeds, in The Agricultural Co-operative Federation of Thailand Research Report, pp. 3-37.

Argyle, J. L. and R. L. Baldwin. 1989. Effects of amino acids and peptides on rumen microbial growth yields. J. Dairy Sci. 72:2017-2027.

Armstrong, D. V. 1994. Heat stress interaction with shade and cooling. J. Dairy Sci. 77: 2044-2050.

Association of Official Analytical Chemists (AOAC). 1990. Official methods of analysis. Washington, DC.

Baker, L. D., J. D. Ferguson and W. Chalupa. 1995. Responses in urea and true protein of milk to different protein feeding schemes for dairy cows. J. Dairy Sci. 78: 2424-2434.

Bequette, B. J., F. R. C. Backwell and L. A. Cromptom. 1998. Current concepts of amino acid and protein metabolism in the mammary gland of the lactating ruminant. J. Dairy Sci. 81: 2540-2559.

Blauwiekel, R. and R. L. Kincaid. 1986. Effect of crude protein and solubility on performance and blood constituents of dairy cows. J. Dairy Sci. 69:2091-2098.

Bremner, J. M. and D. R. Keeney. 1965. Steam distillation methods of determination of ammonium, nitrate and nitrite. Anal. Chem. Acta. 32:363.

Camero, A., M. Ibrahim and M. Kass. 2001. Improving rumen fermentation and milk production with legume-tree fodder in the tropics. Agrofor. Sys. 51:157-166.

Chalupa, W. 1984. Discussion of Protein Symposium. J. Dairy Sci. 67:1134-1146. 
Chanjula, P., M. Wanapat, C. Wachirapakorn and P. Rowlinson. 2004. Effect of synchronizing starch sources and protein (NPN) in the rumen on feed intake, rumen microbial fermentation, nutrient utilization and performance of lactating dairy cows, Asian-Aust. J. Anim. Sci. 17:1400-1410.

Cochran, W. G. and G. M. Cox. 1957. Experimental Designs (2nd edn). John Wiley \& Sons, Oxford, pp. 131.

Erwin, E. S., G. J. Marco and M. E. Emery. 1961. Volatile fatty acid analyses of blood and rumen fluid by gas chromatography. J. Dairy Sci. 44:1768-1771.

Ferguson, J. D., T. Blanchard, D. T. Galligan, D. C. Hoshall, and W. Chalupa. 1988. Infertility in dairy cattle fed a high percentage of protein degradable in the rumen. $\mathrm{J}$. Am. Vet. Med. Assoc. 192:659-662.

Galyean, M. L. 1989. Microscopy, in Laboratory Procedure in Animal Nutrition research. Department of Animal and Range Science, New Mexico State University, USA, pp. 163-168.

Ishler, V., J. Heinrichs and G. Varga. 1996. Feed and feed nutrients for dairy cattle, in From Feed to Milk: Understanding Rumen Function. Pennsylvania State University Extension Circular 422.

Jones-Endsley, J. M., M. J. Cecava and T. R. Johnson. 1997. Effects of dietary supplementation on nutrient digestion and the milk yield of intensively grazed lactating dairy cows. J. Dairy Sci. 80:3283-3292.

Kabuga, J. D. 1990. The influence of thermal conditions on the conception rate of HolsteinFriesian cattle in the humid tropics. Agr. For. Met. 53:33-43.

Kalscheur, K. F., R. L. Baldwin, B. P. Glenn, and R. A. Kohn. 2006. Milk production of dairy cows fed differing concentrations of rumen-degraded protein. J. Dairy Sci. 89:249-259.

Kanjanapruthipong, J. 2006. Dairy Herd Management. Kasetsart University Press, Thailand, p. 230. (in Thai)

Kanjanapruthipong, J., N. Buatong and S. Buaphan. 2001. Effect of roughage neutral detergent fiber on dairy performance under tropical conditions. Asian-Aust. J. Anim. Sci. 14:1400-1404.

Kanjanapruthipong, J., N. Homwong and N. Buatong. 2010. Effects of prepartum roughage neutral detergent fiber levels on periparturient dry matter intake, metabolism, and lactation in heat-stressed dairy cows. J. Dairy Sci. 93:2589-2597. 
Kendall, C., C. Leonardi, P. C. Hoffman and D. K. Combs. 2009. Intake and milk production of cows fed diets that differed in dietary neutral detergent fiber and neutral detergent fiber digestibility. J. Dairy Sci. 92:313-323.

Khampa, S. and M. Wanapat. 2006. Supplementation of urea level and malate in concentrate containing high cassava chip on rumen ecology and milk production in lactating cows. Pakis. J. Nutr. 5:530-535.

Kim, H. J., S. H. Park and W. J. Maeng. 2000. Effects of dietary carbohydrate sources on ruminal ammonia - $\mathrm{N}$ concentration and performance of dairy cows, in Proceedings of the Announcement for the Third Joint Symposium of Japan and Korea on Rumen Metabolism and Physiology: Present and Future of Rumen Research, Miyazaki, Japan, pp. 31.

Korhonen, M., A. Vanhatalo and P. Huhtanen. 2002. Effect of protein source on amino acid supply, milk production, and metabolism of plasma nutrients in dairy cows fed grass silage. J. Dairy Sci. 85:3336-3351.

Leng, R. A. 1990. Factors affecting the utilization of poor -quality forages by ruminants particularly under tropical conditions. Nutr. Res. Rev. 3:277-303.

Moran, J. 2005. Supplements for milking cows, in Tropical Dairy Farming: Feeding Management for Small Holder Dairy Farmers in the Humid Tropics. Landlinks Press. Victoria, Australia.

Mulligan, F. J., P. Dillon, J. J. Callan, M. Rath and F. P. O'Mara. 2004. Supplementary concentrate type affects nitrogen excretion of grazing dairy cows. J. Dairy Sci. 87:3451-3460.

National Research Council (NRC). 1989. Nutrient Requirements of Dairy Cattle (6th edn). National Academy Press, Washington DC.

National Research Council (NRC). 2001. Nutrient Requirements of Dairy Cattle (7th rev. edn). National Academy Press, Washington DC.

Odensten, M. O., Y. Chilliard and K. Holtenius. 2005. Effects of two different feeding strategies during dry-off on metabolism in high-yielding dairy cows. J. Dairy Sci. 88:2072-2082.

Promma, S., S. Puangdee, B. Cheva-Isarakul and B. Cheva-Isarakul. 2002. The proper levels of energy and protein for medium milk yield Holstein-Friesian crossbred cows fed ruzi silage as a major roughage source, in The proceedings of 40th Kasetsart University Annual Conference, Bangkok, Thailand, pp. 163-171. 
Ramos, S., M. L.Tejido, M. E. Martinez, M. J. Ranilla and M. D. Carro. 2009. Microbial protein synthesis, rumenal digestion, microbial populations, and nitrogen balance in sheep fed diets varying in forage-to-concentrate ratio and type of forage. J. Anim. Sci. 87: 2924-2934.

Ravagnolo, O., I. Misztal and G. Hoogenboom. 2000. Genetic component of heat stress in dairy cattle, development of heat index function. J. Dairy Sci. 83:2120-2125.

Reynal, S. M. and G. A. Broderick. 2003. Effects of feeding dairy cows protein supplements of varying ruminal degradability. J. Dairy Sci. 86:835-843.

Ropstad, E., L. Vik-Mo and A. O. Refsdal. 1989. Levels of milk urea, plasma constituents and rumen liquid ammonia in relation to the feeding of dairy cows during early lactation. Acta Vet. Scand. 30:199-208.

SAS Institute Inc. 2001. SAS/STAT User's Guide (Version 8.2 edn). SAS Institute Inc., Cary, North Carolina, USA.

Tyrrell, H. F., G. L. Haaland, P. W. Moe and A. C. G. Brown. 1981. Effect of level and solubility of protein on energy value of corn silage based rations fed to Holstein cows. J. Dairy Sci. 64 (Supp. 1.1):123(Abstr.).

Van Keulen, J. and B. A. Young. 1977. Evaluation of acid-insoluble ash as a natural marker in ruminant digestion studies. J. Anim. Sci. 44:282.

Van Soest, P. J., J. B. Robertson and B. A. Lewis. 1991. Methods for dietary fiber, neutral detergent fiber, and nonstarch polysaccharides in relation to animal nutrition. J. Dairy Sci. 74:3583-97.

Weigel, D. J., J. P. Elliott and J. H. Clark. 1997. Effects of amount and ruminal degradability of protein on nutrient digestibility and production by cows fed tallow. J. Dairy Sci. 80:1150-1159. 


\section{Chapter 6}

General Discussion 


\section{INTRODUCTION}

The relative low milk production of Thai dairy cows is, as outlined in the general introduction of the current thesis, related to the prevailing environmental conditions. The combination of a high air temperature and high humidity leads to heat stress in lactating cows (Davison et al., 1996; Gaughan, et al., 1998), thereby, negatively influencing dry matter intake (DMI) and subsequently milk production, reproduction and cow health (Beede et al., 1986; McDowell, 1972; McGuire et al., 1989; Rhoads et al., 2009; Sanchez, et al., 1994; West, 1994). Heat stress can be attenuated by reducing the heat load of the animal through measures such as provision of shade to reduce incoming radiation, an increase of air velocity and/or lowering of environmental temperature by evaporative cooling. Alternatively, the development of specific dairy breeds can be considered opportune to combat the negative impact of heat stress on dairy production (Beede et al., 1986). Thus measures related to the housing, either or not in combination with the use of cows genetically equipped to cope better with heat stress, are probably needed to ultimately increase dairy production in Thailand towards levels comparable with those commonly observed under temperate conditions. Although the relevance of these topics cannot be disputed, they are, however, beyond the scope of the current thesis.

Needless to say that nutrient supply also has a major impact on milk production of cows kept under hot and humid conditions. The overall objective of the research described in this thesis was, therefore, to provide a nutritional basis for improvement of milk production of Thai dairy cows. Therefore, the results of the experimental studies reported in Chapters 3, 4 and 5 are mainly discussed from a practical point of view.

\section{GENERAL CONSIDERATIONS RELATED TO THE CROSS SECTIONAL STUDY}

The outcome of the cross sectional study reported in the second chapter of this thesis suggests that both the sodium (Na) and protein supply of dairy cows in Thailand are important constraints for milk production. However, in this study the sample size was small (45 cows housed in 6 different farms) and thus the representativeness of the results can be considered a concern and may, therefore, limit extrapolation of the outcomes. On the other hand, the mean $(n=63)$ milk yield (MY), milk fat and protein contents of the cows sampled during the cross sectional study were calculated to be $15.9 \mathrm{~kg}$ milk/cow/day, $4.06 \%$ fat and $2.96 \%$ protein and these values are not too different from the nation's mean values, i.e. $12.2 \mathrm{~kg}$ milk/cow/day (Pattamanont and Ruengpaibul, 2015), 3.70\% fat and 3.03\% protein (Kamphusiri, 2013), respectively. It must be kept in mind that MY was only measured at 70 and 130 days in milk 
during the cross sectional study. Thus, MY was not monitored during the second half/end of the lactation, thereby, explaining the somewhat greater mean MY as observed during the cross sectional study.

In Thailand, the types of feedstuffs fed to the dairy cows, especially forages, depend on geographical location of the farm. In the northeastern part of Thailand (Isan) for instance the principle source of roughage is rice straw while in Chiang Mai province (Northern part of Thailand) by-products of the corn industry such as corn stem and corn cobs (without grain) are the main source of roughage. Moreover, commercial pelleted compound feeds are hardly used in Isan while its use is common in the central part of Thailand. It can, therefore, be argued that data should be collected from each region in Thailand in proportion to the number of cows in each region in order to achieve a representative estimate of the overall Thai feeding conditions. Unfortunately, the geographical distribution of the farms sampled during the cross sectional study does not fully meet this criterion of representativeness. Consequently, the feedstuffs used on the farms that participated in the cross sectional study do not fully reflect the average Thai farm. On the other hand, in terms of nutrient contents, almost all roughages share the same characteristics; i.e. high $\mathrm{ADF}$ ( $\geq 243 \mathrm{~g} / \mathrm{kg} \mathrm{DM}$ ), low Na $(\leq 0.5 \mathrm{~g} / \mathrm{kg} \mathrm{DM})$ and with the exception of cassava leaves and Leucaena leucocephala, low crude protein $(\mathrm{CP})$ contents $(\leq 126 \mathrm{~g} / \mathrm{kg} \mathrm{DM})$ (Table 1, General introduction). Thus, in terms of nutrient composition of the used roughages, the six selected farms can be considered as a fair representation of the average Thai farm.

\section{SODIUM SUPPLY AND REQUIREMENTS OF THAI DAIRY COWS}

The outcome of the cross sectional study indicated that the sodium (Na) supply of dairy cows in Thailand is an important constraint of milk production because an observed positive correlation between $\mathrm{Na}$ intake and MY. This positive correlation could not be easily explained due to the confounding effect of concentrate intake. Thus, the cause and effect relationship of $\mathrm{Na}$ intake and $\mathrm{MY}$ was not clear but there are indications that heat stressed versus non heat stressed cows require greater amounts of Na. Sanchez et al. (1994) suggested that heat stressed cows require greater amounts of $\mathrm{Na}$ due to greater $\mathrm{Na}$ losses with sweat. Thus, the current recommendations, which were set from studies conducted with cows maintained under temperate conditions (i.e. 0.5 to $2.2 \mathrm{~g} / \mathrm{kg} \mathrm{DM}$, Chapter 3) may not apply to cows living under hot and humid environmental conditions as present in Thailand. Unfortunately, there is a dearth of studies addressing the issue of $\mathrm{Na}$ requirements of heat 
stressed cows and it was, therefore, considered relevant to gain more insight into this, for milk production under tropical environmental conditions, important topic.

In general, $\mathrm{Na}$ status of animals can be determined using $\mathrm{Na}$ balance studies as the amount of $\mathrm{Na}$ absorbed in excess of requirement is rapidly excreted in urine. During $\mathrm{Na}$ deficiency (negative $\mathrm{Na}$ balance), there is an aldosterone induced decrease of $\mathrm{Na}$ urinary excretion with a concomitant decrease of the salivary Na concentration which is accompanied by a simultaneous increase of the salivary $\mathrm{K}$ concentration. Therefore, the salivary $\mathrm{Na} / \mathrm{K}$ ratio is a more practical indicator of $\mathrm{Na}$ status in ruminants. A salivary $\mathrm{Na} / \mathrm{K}$ ratio lower than 6 is indicative for Na deficiency (Schonewille and Beynen, 2005).

\section{The impact of dietary sodium on milk yield}

In the current studies into the Na metabolism of dairy cows (Chapters 3 and 4), both dry matter intake and MY were affected by the Na content of the ration (Table 1). For the two studies combined (Thiangtum et al., 2011, 2017), it was found that an increase of $1 \mathrm{~g} \mathrm{Na} / \mathrm{kg}$ DM resulted in an increase of $0.91 \mathrm{~kg}$ of milk and $0.27 \mathrm{~kg}$ dry matter. This result is corroborated by Schneider et al. $(1984,1986,1988)$ and Silanikove et al. (1998) who also reported increased MY and dry matter intake in response to a greater dietary $\mathrm{Na}$ content (Table 1). The latter four studies were all conducted under heat stress conditions and across those four studies, MY and dry matter intake were increased by 0.47 and $0.26 \mathrm{~kg}$, respectively when the dietary Na content was increased by $1 \mathrm{~g} / \mathrm{kg} \mathrm{DM}$. Moreover, Sanchez et al. (1994) modeled milk production and nutrition data from 15 studies that were conducted during summertime in southern USA and they found maximum MYs when the ration contained $\sim 7 \mathrm{~g} \mathrm{Na} / \mathrm{kg}$ DM. The greater milk yields can be explained by the greater intake of dry matter but it is not easy to explain why the intake of dry matter increases in response to a greater $\mathrm{Na}$ content in the ration. Perhaps, the greater $\mathrm{Na}$ intakes caused greater water intakes, thereby, increasing the influx of water into the rumen and subsequently accelerated the flow of liquid digesta out of the rumen. Such conditions may increase the efficiency of fibre digestion (Rogers and Davis, 1982; Rogers et al., 1982) and, therefore, increase dry matter intake. 
Table 1. Dry matter intake (DMI) and milk yield (MY) in response to the dietary Na content

\begin{tabular}{|c|c|c|c|c|c|}
\hline \multirow{2}{*}{ Reference } & \multirow{2}{*}{$\begin{array}{c}\text { Dietary Na } \\
\text { g/kg DM }\end{array}$} & \multirow{2}{*}{$\begin{array}{l}\text { DMI } \\
\mathrm{kg} / \mathrm{d}\end{array}$} & \multirow{2}{*}{$\begin{array}{l}\text { MY } \\
\mathrm{kg} / \mathrm{d}\end{array}$} & \multicolumn{2}{|c|}{ Response $^{\mathrm{a}}$} \\
\hline & & & & DMI & MY \\
\hline \multirow[t]{2}{*}{ Schneider et al., 1984} & 6.6 & 18.1 & 17.9 & \multirow{2}{*}{0.43} & \multirow{2}{*}{0.20} \\
\hline & 9.6 & 19.4 & 18.5 & & \\
\hline \multirow[t]{2}{*}{ Schneider et al., 1986} & 1.8 & 18.2 & 19.1 & \multirow{2}{*}{0.03} & \multirow{2}{*}{0.24} \\
\hline & 5.5 & 18.3 & 20.0 & & \\
\hline \multirow[t]{2}{*}{ Schneider et al., 1988} & 1.9 & 21.0 & 17.4 & \multirow{2}{*}{0.06} & \multirow{2}{*}{0.18} \\
\hline & 6.8 & 21.3 & 18.3 & & \\
\hline \multirow[t]{2}{*}{ Silanikove et al., 1998} & 2.2 & 15.4 & 26.2 & \multirow{2}{*}{0.53} & \multirow{2}{*}{1.27} \\
\hline & 3.7 & 16.2 & 28.1 & & \\
\hline \multirow[t]{2}{*}{ Thiangtum et al., 2011} & 1.6 & 16.3 & 14.9 & \multirow{2}{*}{0.33} & \multirow{2}{*}{0.62} \\
\hline & 4.0 & 17.1 & 16.4 & & \\
\hline \multirow[t]{2}{*}{ Thiangtum et al., 2017} & 1.2 & 12.5 & 14.4 & \multirow{2}{*}{0.20} & \multirow{2}{*}{1.20} \\
\hline & 1.7 & 12.6 & 15.0 & & \\
\hline
\end{tabular}

${ }^{a}$ Within studies the response in DMI to the dietary Na content is calculated as $\Delta \mathrm{DMI}(\mathrm{kg} /$ day $) / \Delta$ dietary $\mathrm{Na}(\mathrm{g} / \mathrm{kg} \mathrm{DM})$. The response in MY is calculated similarly.

\section{Sodium requirement of heat stressed cows}

A first estimation of the $\mathrm{Na}$ requirement of lactating cows in a tropical environment based on literature data was provided in Chapter 3. The value of $1.2 \mathrm{~g} \mathrm{Na} / \mathrm{kg} \mathrm{DM}$ was the mean of the various estimates on Na requirements as set by different authorities (ARC, 1980; CVB, 2005; DLG, 2001; INRA, 1989; NRC, 2001; Underwood and Suttle, 1999) instead of the result of experimental data. In case the factorial method is used (Table 2) to calculate the $\mathrm{Na}$ requirement of a cow with body weight (BW) of $485 \mathrm{~kg}$ producing $15 \mathrm{~kg}$ of milk (Thiangtum et al., 2011), the daily $\mathrm{Na}$ requirement is calculated to be $11.3 \mathrm{~g}$ and this value is $43 \%$ lower than the estimated Na requirement using the value of $1.2 \mathrm{~g} / \mathrm{kg}$ DM in combination with a DM intake of $16.5 \mathrm{~kg} /$ day (Thiangtum et al., 2011). Thus, at first glance, the tentative value set in Chapter 3 appears to overestimate the Na requirement. However, the values used by the CVB (2005) do not take into account the extra $\mathrm{Na}$ losses with sweat in heat stress conditions and as such $\mathrm{Na}$ losses with increased sweat production are not taken into account in this estimate. 
Table 2. Sodium (Na) requirement of a dairy cow with a body weight of $485 \mathrm{~kg}$, producing $15 \mathrm{~L}$ of milk.

\begin{tabular}{|c|c|c|c|c|}
\hline \multirow[t]{2}{*}{ Parameter $^{\mathrm{a}}$} & \multicolumn{4}{|c|}{ Na losses } \\
\hline & Faeces & Urine & Dermal & Milk \\
\hline \multicolumn{5}{|l|}{ Endogenous losses } \\
\hline $\mathrm{mg} / \mathrm{kg}$ body weight & 5.1 & 1.0 & 0.6 & \\
\hline g/day & 2.5 & 0.5 & 0.3 & \\
\hline \multicolumn{5}{|l|}{ Milk } \\
\hline $\mathrm{g} / \mathrm{L}$ & & & & 0.46 \\
\hline \multirow[t]{2}{*}{ g/day } & & & & 6.9 \\
\hline & & \multicolumn{3}{|c|}{ Na requirements (g/day) } \\
\hline \multicolumn{2}{|c|}{ Net requirement for maintenance (M) } & \multicolumn{3}{|c|}{3.2} \\
\hline \multicolumn{2}{|c|}{ Net requirement for $\mathrm{M}$ and $15 \mathrm{~L}$ milk } & \multicolumn{3}{|c|}{10.1} \\
\hline \multicolumn{2}{|l|}{ Gross requirement for $\mathrm{M}$} & \multicolumn{3}{|c|}{3.6} \\
\hline \multicolumn{2}{|c|}{ Gross requirement for $\mathrm{M}$ and $15 \mathrm{~L}$ milk } & \multicolumn{3}{|c|}{11.3} \\
\hline
\end{tabular}

${ }^{a}$ The gross Na requirement is calculated using an efficiency of true $\mathrm{Na}$ absorption of 90\% (Schonewille and Beynen, 2005).

Quantitative data on the $\mathrm{Na}$ losses with sweat are provided by Jenkinson and Mabon (1973) and they reported that $\mathrm{Na}$ losses with sweat range from 7.1 to $10 \mathrm{mg} / \mathrm{m}^{2} / \mathrm{h}$ when THI ranged from 79 to 81 . Under the assumption that a cow with a body weight of $485 \mathrm{~kg}$ (estimated surface area $4.75 \mathrm{~m}^{2}$ (Brody, 1945)) experience $4 \mathrm{~h}$ of mild (THI 72-79), 19h of moderate (THI 79-89) and 1h of severe (THI > 89) heat stress each 24h (Thiangtum et al., 2017), it can be calculated that such a cow loose $\sim 3 \mathrm{~g} \mathrm{Na}$ /day via sweat. Addition of the latter value to the $\mathrm{Na}$ requirement already mentioned (i.e. $11.3 \mathrm{~g} /$ day) results in a maximum $\mathrm{Na}$ requirement of $14.6 \mathrm{~g} /$ day for a cow weighing $485 \mathrm{~kg}$, producing $15 \mathrm{~kg}$ of milk and suffering from heat stress. Thus, in case the ration contains of $1.2 \mathrm{~g} \mathrm{Na} / \mathrm{kg} \mathrm{DM}$, the cows need to ingest minimally $12.2 \mathrm{~kg} \mathrm{DM} /$ day to meet their Na requirement. This minimum level of DM intake is generally achieved under Thai feeding conditions (Chapter 2). It, therefore, seems that the tentative value on the Na requirement set by Thiangtum et al. (2011) is a reasonable estimate for the required dietary $\mathrm{Na}$ content under Thai feeding conditions. However, it appeared that there is a considerable discrepancy between the Na losses with sweat calculated on the basis of data obtained by $\mathrm{Na}$ depletion and subsequent $\mathrm{Na}$ repletion (Thiangtum et al., 2017) and the data provided by Jenkinson and Mabon (1973), and without further research they cannot be explained. Thus, the lack of unequivocal estimates on the $\mathrm{Na}$ losses with sweat, hinders 
potential refinement of the previous recommendation (i.e. $1.2 \mathrm{~g} \mathrm{Na} / \mathrm{kg} \mathrm{DM}$ ) regarding the $\mathrm{Na}$ requirement of lactating cows under tropical conditions.

Apart from the $\mathrm{Na}$ losses with sweat, the endogenous $\mathrm{Na}$ losses with faeces, and the $\mathrm{Na}$ content of milk are major determinants of the net Na requirement (Table 2). Data on endogenous fecal $\mathrm{Na}$ losses were not obtained during the current studies (Chapters 3 and 4) but in Chapter 3 it was reported that cows consuming either 6.9 or $26.3 \mathrm{~g} \mathrm{Na}$ /day lost respectively, 1.4 or $3.0 \mathrm{~g} \mathrm{Na}$ /day with their faeces. Under the assumption that the efficiency of true $\mathrm{Na}$ absorption is $90 \%$ of intake (Schonewille and Beynen, 2005) and body weight of the cows is $485 \mathrm{~kg}$, endogenous fecal $\mathrm{Na}$ losses are calculated to be 1.5 and $0.8 \mathrm{mg} / \mathrm{kg} \mathrm{BW}$ when cows ingest 6.9 or $26.3 \mathrm{~g} \mathrm{Na} /$ day, respectively. These calculated values are much lower than those listed in Table 2 but the issue of endogenous fecal $\mathrm{Na}$ loss is complicated and hitherto there is much uncertainty on this topic.

The current value on the endogenous fecal $\mathrm{Na}$ loss is estimated from $\mathrm{Na}$ balance data and derived from regressing fecal $\mathrm{Na}$ output against $\mathrm{Na}$ intake (Schonewille and Beynen, 2005). Using this approach, the endogenous faecal $\mathrm{Na}$ losses are assumed to be represented by the faecal $\mathrm{Na}$ losses at zero $\mathrm{Na}$ intake; i.e. the intercept of the regression formula. It can, however, be disputed whether this approach can be conceptually defended because considerable exchange of $\mathrm{Na}$ can occur between the extracellular body pool and the contents of the gastro-intestinal tract (ARC, 1980; Bell, 1995). Moreover, it was suggested by Schonewille and Beynen (2005) that inevitable Na losses associated with mucosal cells and gastro-intestinal juices are, at least in quantitative terms, negligible. From this viewpoint, the German (DLG, 2001) approach to estimate the maintenance requirement of $\mathrm{Na}$ on the basis of the $\mathrm{Na}$ content of fecal water is from a physiological viewpoint more attractive and they (DLG, 2001) adopted a value of $0.35 \mathrm{~g} \mathrm{Na} / \mathrm{kg}$ faecal water as an estimate for the maintenance requirement of $\mathrm{Na}$. However, the latter value most likely overestimates the inevitable loss of $\mathrm{Na}$ with faeces because the DLG (2001) reports also that the Na concentration in faecal water can drop at least to $0.12 \mathrm{~g} / \mathrm{kg}$ faecal water. These values are more or less in line with the values reported by Boehncke et al. (1983) and Renkema et al. (1962) who reported that the $\mathrm{Na}$ concentration in fecal water can drop to value as low as $0.07 \mathrm{~g} \mathrm{Na} / \mathrm{kg}$. Clearly, the issue on the inevitable faecal $\mathrm{Na}$ excretion is not settled yet and may also depend on the dietary intake of K. It has been shown, at least in sheep that an increase of the $\mathrm{K}$ intake results in a decrease of the faecal Na excretion (Greene et al., 1983; Rahnema and Fontenot, 1986; Suttle and Field, 1967). It thus appears that a drop in the $\mathrm{Na}$ concentration of faecal water is accompanied by a rise in the $\mathrm{K}$ concentration of faecal water, thereby, keeping the sum of $\mathrm{Na}$ 
and K more or less constant (DLG, 2001; Van Weerden, 1959). Taken the aforementioned into account, it is clear that it seems without doubt that more research is needed to properly estimate the maintenance requirement of $\mathrm{Na}$ under various physiological conditions. It is obvious that the issue of endogenous faecal $\mathrm{Na}$ loss also affects the estimate of true $\mathrm{Na}$ absorption and the value listed in Table 2 may underestimate the efficiency of true $\mathrm{Na}$ absorption. Indeed, Delaquis and Block (1995a) reported values on apparent $\mathrm{Na}$ absorption ranging from 93.3 to $95.9 \%$ of intake and the latter value is almost the same as the value reported in Chapter $3(96.1 \%)$.

In the studies on Na reported in Chapter 3 and 4, the Na contents in milk were found to range from 0.21 to $0.62 \mathrm{~g} / \mathrm{L}$ with an overall mean Na content of $0.35 \mathrm{~g} / \mathrm{L}$. Thus, the overall mean $\mathrm{Na}$ content of milk as measured in the current studies was $\sim 24 \%$ lower than the value listed in Table 2. The latter value, however, is the overall mean that was calculated using the values on the $\mathrm{Na}$ content of milk (i.e. ranging from 0.40 to $0.63 \mathrm{~g} \mathrm{Na} / \mathrm{L}$ ) adopted by various authorities (ARC, 1980; CVB, 1996; DLG, 2001; NRC, 2001; INRA, 1989) and values from individual studies (Delaquis and Block, 1995a; Kemp, 1964; Shalit et al., 1991; Silanikove et al., 1997). Kemp (1964) observed a Na content of milk ranging from 0.31 to $0.49 \mathrm{~g} \mathrm{Na} / \mathrm{L}$, with a mean value of $0.38 \mathrm{~g} \mathrm{Na} / \mathrm{L}$ and mean $\mathrm{Na}$ contents of milk reported by Delaquis and Block (1995b), Shalit et al. (1991) and Silanikove et al. (1997) were 0.29, 0.42 and $0.45 \mathrm{~g} / \mathrm{kg}$, respectively. It thus appears that the Na contents of milk as measured in the current study fall well within the range of values reported in the literature.

Taken all aforementioned considerations into account, it can be suggested that the endogenous faecal $\mathrm{Na}$ losses as presented in Table 2, are overestimated and the efficiency of true $\mathrm{Na}$ absorption is underestimated. Moreover, in the current study, $\mathrm{Na}$ contents in milk were lower than $0.46 \mathrm{~g} / \mathrm{L}$ (Table 2). Thus, it seems that the previous calculation on the $\mathrm{Na}$ requirement of cows, i.e. $11.3 \mathrm{~g} /$ day, already overestimates the actual Na requirement of cows living under temperate conditions. This implies that the gap in $\mathrm{Na}$ requirements of heat stressed versus non heat stressed is even greater than previously assumed. This notion strengthens the previous conclusion that the $\mathrm{Na}$ losses associated with heat stress are much greater than indicated by Jenkinson and Mabon (1973).

In the experiments reported in Chapter 3 and 4, salivary $\mathrm{Na}$ concentrations in the $\mathrm{Na}$ depleted cows ranged from 132 to $82.1 \mathrm{mmol} / \mathrm{L}$ while salivary K concentrations ranged from 10.2 to $44.2 \mathrm{mmol} / \mathrm{L}$. In Na-deficient cattle there is a replacement of $\mathrm{Na}^{+}$with $\mathrm{K}^{+}$in the saliva, causing a reduction in $\mathrm{Na} / \mathrm{K}$ ratio (Murphy and Connell, 1970; Underwood and Suttle, 1999). Based on these experiments, the $\mathrm{Na} / \mathrm{K}$ ratio ranged from 14.6 to 2.3 . The salivary 
$\mathrm{Na} / \mathrm{K}$ ratio lower than 6 was used for the diagnostic tool of Na deficiency (Schonewille and Beynen, 2005). After dietary induced $\mathrm{Na}$ deficiency (Chapter 4), cows showed a $\mathrm{Na} / \mathrm{K}$ ratio in saliva lower than 4 in the first week with associated with signs of pica. The present study thus shows that the $\mathrm{Na} / \mathrm{K}$ ratio in the saliva of cows is an accurate and convenient measure to diagnose Na deficiency.

\section{PROTEIN SUPPLY AND MILK PRODUCTION OF THAI DAIRY COWS}

A positive correlation was found between protein intake and MY in early lactating dairy cows in Thailand (Chapter 2). This observation can be interpreted in that protein intake is relevant to improve dairy production in Thailand. Unfortunately, the correlation between protein intake and MY cannot be easily explained because the cause and effect relationship is not clear due to the confounding effect of energy intake.

The issue on protein supply was addressed in Chapter 5 as well and in this study, an increase of the dietary CP content from 15.4 to $16.6 \%$ (DM basis) was associated with an increase of $1.0 \mathrm{~kg}$ of milk. The observed increase in MY in response to the increase in the dietary $\mathrm{CP}$ content, is similar to the amount that can be predicted with regression formula derived from a meta-analysis conducted by Ipharraguerre and Clark (2005). The increase in MY (Chapter 5) was associated with an increase in DMI, i.e. $0.5 \mathrm{~kg}$. Thus, in this study too, the effect of dietary CP content on MY was confounded by DM intake and, therefore, with energy intake. On the other hand, the observation of a stimulatory effect on DM intake in response to an increase of the dietary $\mathrm{CP}$ content, is in line with a substantial body of evidence as reviewed by Oldham et al. (1984). It thus appears that, at least under the condition of ad libitum supply of feed, it is not possible to demonstrate a cause and effect relationship between the dietary CP content and MY. In contrast to MY, the yield of milk protein (kg/day) was not significantly affected by the increase of the dietary CP content and thus protein intake. Consequently, the increase in dietary CP content was associated with a decrease in the efficiency of nitrogen utilization (i.e. $\mathrm{N}$-milk/ $\mathrm{N}$ intake $\times 100 \%$ ). This result can be interpreted in that the protein ingested in surplus to the low $\mathrm{CP}$ ration (i.e. 1.8 to 2.0 $\mathrm{kg} /$ day, Chapter 5) was used as a source of energy rather than a source of protein to synthesize milk protein. This notion is corroborated by the observation that the blood urea nitrogen (BUN) concentration increased from 12.2 to $14.7 \mathrm{mg} / \mathrm{dL}$ when the cows were fed the high instead of the low CP ration. On the other hand, BUN is also related to the ammonia $\left(\mathrm{NH}_{3}\right)$ concentration in rumen (Odensten et al., 2005; Ropstad et al., 1989) and rumen $\mathrm{NH}_{3}$ concentrations increased from 24.3 to $28.3 \mathrm{mg} / \mathrm{dL}$ when cows were fed low or high CP 
rations, respectively (Chapter 5). Although $\mathrm{NH}_{3}$ is important for growth of rumen microbes, it can be disputed whether an increase from 24.3 to $28.3 \mathrm{mg} / \mathrm{dL}$ in rumen $\mathrm{NH}_{3}$ concentrations has the potency to effectively stimulate microbial growth (Dijkstra et al., 1998). Under the assumption that $\mathrm{N}$ supply to rumen microbes is the only limiting factor for their growth, maximum growth rate of rumen microbes is achieved when rumen $\mathrm{NH}_{3}$ concentration is $\sim 51$ $\mathrm{mg} / \mathrm{dL}$ (Dijkstra et al., 1998, value is converted for the sake of comparison). However, in case the rumen $\mathrm{NH}_{3}$ concentration is $24.3 \mathrm{mg} / \mathrm{dL}$, maximum growth rate is estimated to be only $\sim 5 \%$ lower compared to a rumen $\mathrm{NH}_{3}$ concentration of $51 \mathrm{mg} / \mathrm{dL}$. It can be suggested that the increase in rumen degradable protein (Chapter 5) was too small to effectively enhance microbial growth and, therefore, the flow of microbial protein from the rumen to the small intestine.

Next to $\mathrm{N}$, either in the form of $\mathrm{NH}_{3}$, amino acids or small peptides (Hackmann and Firkins, 2015), rumen microbes also require energy (i.e. ATP) to grow. This ATP is synthesized during rumen fermentation when organic matter is converted into volatile fatty acids (i.e. predominantly acetic acid, propionic acid and butyric acid). Thus, the amount of fermentable organic matter (FOM) that is ingested by ruminants is an important determinant of microbial growth and, therefore, the amount of microbial protein available for, amongst others, milk production. From this viewpoint, the content of fermentable carbohydrates in Thai dairy rations is of interest. In tropical countries, including Thailand, forages generally have high fibre contents (i.e. NDF, ADF and ADL, general introduction) and are, therefore, difficult to ferment by the rumen microbiota. It may, therefore, be that the forages used in Thai dairy practice are a poor source of energy for rumen microbes and thus limit microbial protein synthesis. From this viewpoint, caution is warranted to supplement Thai dairy rations with rumen degradable protein (RDP) because the $\mathrm{N}$ that originates from this RDP may not be incorporated in microbial protein and subsequently in milk protein, thereby, leading to low efficiency of $\mathrm{N}$ utilization. Hitherto, the FOM contents of Thai dairy feedstuffs are unfortunately not quantified and it can be suggested that this lack of knowledge hinders optimization of Thai dairy rations in terms of protein supply to the cows and, therefore, milk production in Thailand. 


\section{MILK YIELD AND MILK FAT CONTENT IN THAI DAIRY COWS}

The most important trait for Thai dairy producers is MY because it is directly associated with the income of the farmer. In addition, the content of milk fat is also of importance because it is considered in setting the price of milk (Thai Milk Board, 2016). The \% of milk fat relative to other countries is quite low in Thailand (i.e. 3.70\% fat, Kamphusiri, 2013) and the Thai Milk Board has currently set a standard for the minimum fat content of milk. The milk prize of milk that contains less than $3.4 \%$ of fat is reduced by the milk collecting center. Currently, an increasing number of farmers face the problem that their milk is not accepted by cooperatives due to the low fat content in milk. The issue of low milk fat is, therefore, of considerable interest in Thailand.

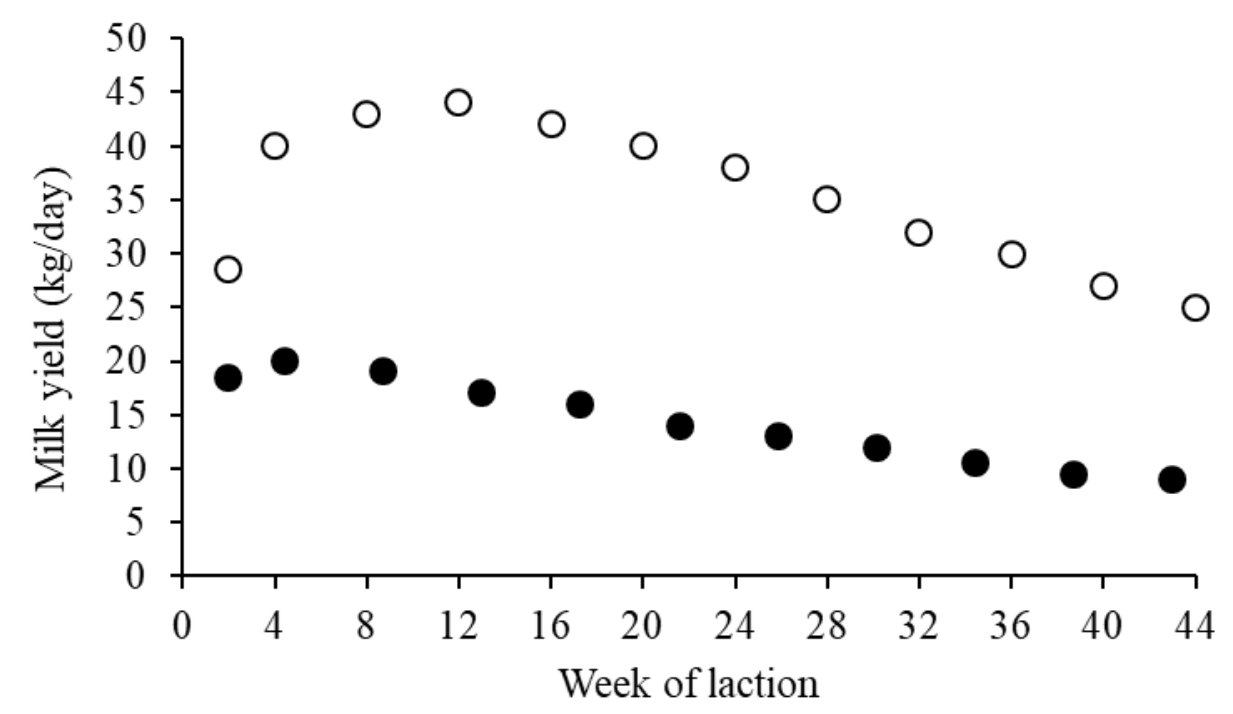

Figure 1. Milk yield in the course of time of cows producing either $\sim 4,400(\bullet$, Seangjun et al., 2009) or $\sim 10,800 \mathrm{~kg}$ of milk (०, Wu and Satter, 2000) during 305 days of lactation.

It was already mentioned that Thai dairy cows produce, on average, $12.2 \mathrm{~kg}$ milk/day (Pattamanont and Ruengpaibul, 2015) containing 3.70\% fat (Kamphusiri, 2013). Thus, the amount of milk produced in 305 days is, on average, $3,721 \mathrm{~kg} / \mathrm{cow}$. In the central part of Thailand, the most important dairy region in the country, the $305 \mathrm{~d}$ milk production is around $18 \%$ greater than the nations mean (i.e. $\sim 4,400 \mathrm{~kg}$ ) but still can be considered low. Compared to cows producing $\sim 10,800 \mathrm{~kg}$ milk/305 days, peak MY is low and this is considered the primary cause of the low $305 \mathrm{~d}$ milk production in Thai dairy cows because MY persist well over time (Figure 1). 
In light of the low level of MY in Thailand, a high milk fat content is expected because it is well known that MY and milk fat content are inversely related (Gaunt, 1980). However, as already mentioned, the fat content of milk is generally low in Thailand. The milk fat content of the cows sampled during the cross sectional study was found to be $4.06 \%$ (Chapter 2), while Kamphusiri (2013) and Yeamkong et al. (2010) reported 3.70\% and 3.4\%, respectively. In contrast, $\mathrm{Wu}$ and Satter (2000) for instance reported milk fat contents of $3.99 \%$ and $3.92 \%$ in combination with 39.1 and $32.6 \mathrm{~kg}$ milk, respectively in US dairy cows. It, therefore, seems plausible that the low fat $\%$ in milk of Thai dairy cows is not caused by a high level of MY. Instead, it can be speculated that the cows lack sufficient precursors of milk fat, at least relative to that of lactose (i.e. the principle determinant of MY (Linn, 1988)) to maintain an acceptable fat content in the milk.

The predominant fat in milk is triacylglycerol, which contains short- $\left(\mathrm{C}_{4}-\mathrm{C}_{10}\right)$, intermediate- $\left(\mathrm{C}_{12}-\mathrm{C}_{16}\right)$, or long-chain $\left(\mathrm{C}_{18}\right)$ fatty acids (Linn, 1988). The short-chain fatty acids are synthesized within the mammary gland from acetate and B-hydroxybutyrate; longchain fatty acids are almost exclusively derived from blood plasma fatty acids of dietary origin; and intermediate-chain acids arise from both sources. In broad terms, approximately 50-60 percent of the fatty acids in milk are synthesized in the mammary gland and the other 40-50 percent are derived directly from blood (Linn, 1988). Thus, both acetate and Bhydroxybutyrate are important precursors of fatty acid synthesis in ruminant mammary cells (Palmquist, 2006) and both volatile fatty acids originate from organic matter that is fermented in the rumen, i.e. FOM. It is well known that at a high rate of fermentation, the profile of volatile fatty acids shifts from acetate to propionate (Moran, 2005). Thus in case of a given amount of FOM, MY is enhanced because of greater availability of propionate to generate lactose. At the same time, lower amounts of milk fat can be generated due to lower amounts of precursors to generate milk fat and thus \% of milk fat will drop. In view of the latter, the amount of FOM that originates from roughages can be considered important to potentially increase the milk fat\% because this type of FOM generally has a low rate of fermentation (Noziere et al., 2011) and thus yields greater proportions of acetate. In view of the chemical composition of the major roughages used in Thailand (General introduction), it can be speculated that the contribution of absolute amounts of acetate that originates from those roughages is low because of their low FOM and thus only marginally contribute to the generation of milk fat. Fibrous feeds are characterized in general by less propionate shifted fermentation with more methane production as compared with concentrate. Improvement of roughage quality is crucial in the utilization of fibrous feeds for sustainable livestock 
production. There are many methods to improve roughage quality such as breeding, physical methods, chemical treatment methods and biological methods. Each method has different advantages and disadvantages, such as: breeding methods are effective but progress is slow, thermal treatment by steam improves nutritive value of waste product. Chemical treatments i.e. oxidizing agents (peroxyacetic acids, acidified sodium chloride, ozone etc.) decompose fairly efficiently the lignin and hydrolyzed agents $(\mathrm{NaOH}, \mathrm{KOH}, \mathrm{CaOH}$, ammonia, urea, etc.) are able to hydrolyze the chemical bonds formed between the indigestible lignin and the parietal polysaccharides (cellulose, hemicellulose) resulted in complete digestion or partial digestion (Chenost and Kayouli, 1997). Biological treatment i.e. enzymatic agents with cellulolytic and hemicellulolytic capability are added to fibrous feed in attempts to improve nutrient digestibility (Abdel-Aziz et al., 2015) and fungal treatments such as white rot fungi can decrease lignin and increase digestion (Shrivastava et al., 2011).

\section{GENERAL CONCLUSIONS}

- The Na supply of dairy cows in Thailand is an important constraint for milk production because of an observed positive correlation between $\mathrm{Na}$ intake and milk yield.

- Both dry matter intake and milk yield were affected by the Na content of the ration. An increase of $1 \mathrm{~g} \mathrm{Na} / \mathrm{kg}$ DM resulted in an increase of $0.91 \mathrm{~kg}$ of milk and 0.27 kg DM.

- The salivary $\mathrm{Na} / \mathrm{K}$ ratio is a more practical indicator of $\mathrm{Na}$ status in ruminants. A salivary $\mathrm{Na} / \mathrm{K}$ ratio lower than 6 appears to be a good indicator for $\mathrm{Na}$ deficiency.

- The Na requirements of heat stressed lactating dairy cows are much greater than non-heat stressed cows. The Na losses associated with heat stress are much greater than indicated by different authorities.

- Dry matter intake responds to an increase of the dietary crude protein content.

- The milk protein yield (kg/day) was not significantly affected by an increase of the dietary crude protein content and thus protein intake. 


\section{REFERENCES}

Abdel-Aziz, A., A. Z. M. Salem, M. M. El-Adawy, L. M. Camacho, A. E. Kholif, M. M. Y. Elghandour and B. E. Borhami. 2015. Biological treatments as a mean to improve feed utilization in agriculture animals- An overview. J. Integr. Agric. 14:534-543.

Agricultural Research Council (ARC). 1980. The Nutrient Requirements of Ruminant Livestock. CAB, Farnham Royal, UK.

Beede, D. K. and R. J. Collier. 1986. Potential nutritional strategies for intensively managed cattle during thermal stress. J. Anim. Sci. 62:543-554.

Bell, F. R. 1995. Perception of sodium and sodium appetite in farm animals, in Sodium in Agriculture, ed. by Phillip C. J. C. and P. C. Chiy. Chalcombe Publications, Canterbury, UK, pp. 82-90.

Boehncke, E., G. Mergardt, I. Fricke and R. Noack. 1983. Methods for Evaluating the Sodium Supply of Dairy Cows. Methodische Untersuchungen zur Diagnostik der Natriumversorgungslage bei Milchkühen. Fortschritte der Veterinärmedizin 37: 186189.

Brody, S. 1945. Bioenergetics and growth: with special reference to the energetic efficiency complex, in Domestic Animals, Reinhold, New York, pp. 354-403.

Central Bureau for Livestock Feeding (CVB). 1996. Handleiding Mineralenonderzoek bij Rundvee in de Praktijk. Commissie Onderzoek Minerale Voeding, 5th edn, Lelystad, The Netherlands.

Central Bureau for Livestock Feeding (CVB). 2005. Handleiding Mineralenvoorziening Rundvee, Schapen, Geiten. (Manual for Mineral Supply Cattle, Sheep, Goats). CVB, Lelystad, Netherlands.

Chenost, M. and C. Kayouli. 1997. Roughage utilization in warm climates, FAO Animal Production and Health Paper 135. Food and Agriculture Organization, Rome, p. 226.

Davison, T., M. McGowan, D. Mayer, B. Young, N. Jonsson, A. Hall, A. Matschoss, P. Goodwin, J. Gaughan and M. Lake. 1996. Managing Hot Cows in Australia: Information Series. Department of Primary Industries Queensland, Australia.

Delaquis, A. M. and E. Block. 1995a. Dietary cation-anion difference, acid-base status, mineral metabolism, renal function, and milk production of lactating cows. J. Dairy Sci. 78:2259-2284.

Delaquis, A. M. and E. Block. 1995b. The effects of changing ration ingredients on acid-base status, renal function, and macromineral metabolism. J. Dairy Sci. 78:2024-2039. 
Dijstra, J., J. France and D. R. Davies. 1998. Different mathematical approaches to estimating microbial protein supply in ruminants. J. Dairy Sci. 81:3370-3384.

DLG. 2001. Ausschuss für Bedarfsnormen der Gesellschaft für Ernährungsphysiologie; Energie-und Nährstoffbedarf Landwirtschaftlicher Nutztiere. DLG-verlag Nr.8. Empfehlungen zur Energie-und Nährstoffversorgung der Milchkühe und Aufzuchtsrinder. DLG-verlag, Frankfurt, pp. 71-88.

Gaughan, J. B., P. J. Goodwin, T. A. Schoorl, B. A. Young, M. Imbeah, T. L. Mader and A. Hall. 1998. Shade preferences of lactating Holstein-Friesian cows. Aust. J. Exp. Agric. 38:17-21.

Gaunt, S. N. 1980. Genetic variation in the yields and contents of milk constituents. Int. Dairy Fed. Bull. Doc. 125:73.

Greene, L. W., Jr. K. E. Webb and J. Fontenot. 1983 Effect of potassium level on site of absorption of magnesium and other macroelements in sheep. J. Anim. Sci. 56:12141221.

Gueguen, L., M. Lamand and F. Meschy. 1989. Mineral requirements, in Ruminant Nutrition: Recommended Allowance and Feed Tables, ed. by Jarrige R. INRA/John Libbey, Paris, pp. 49-59.

Hackmann, T. J. and J. L. Firkins. 2015. Maximizing efficiency of rumen microbial protein production. Front. Microbiol. 6:465.

Ipharraguerre, I. R. and J. H. Clark. 2005. Impacts of the source and amount of crude protein on the intestinal supply of nitrogen fractions and performance of dairy cows. J. Dairy Sci. 88: E22-E37 (E. Suppl.).

Jenkinson, D. M. and R. M. Mabon. 1973. The effect of temperature and humidity on skin surface $\mathrm{pH}$ and the ionic composition of skin secretions in Ayrshire cattle. Br. Vet. J. 129:282-295.

Kamphusiri, N. 2013. Milk Quality Control of Raw Milk in Thailand. Milk and milk product quality control division, Bureau of quality control of livestock product, Department of Livestock Development. Available at http://certify.dld.go.th/th/images/executive/2557/April/21042556/1/04.pdf. Downloaded on August 26, 2016.

Kemp, A. 1964. Sodium requirement of milking cows: balance trials with cows on rations of freshly mown herbage and on winter rations. Netherlands J. Agri. Sci. 12:263-280. 
Linn, J. G. 1988. Factors affecting the composition of milk from dairy cows, in Designing Foods: Animal Product Options in the Marketplace. National Academy Press, Washington, DC.

McDowell, R. E. 1972. Improvement of Livestock Production in Warm Climates. W. H. Freeman and Company, San Francisco, California.

McGuire, M. A., D. K. Baede, M. A. DeLorenzo, C. J. Wilcox, G. B. Huntington, C. K. Reynolds and R. J. Collier. 1989. Effects of thermal stress and level of feed intake on portal plasma flow and net fluxes of metabolites in lactating Holstein cows. J. Anim. Sci. 67:1050-1060.

Moran, J., 2005. How the rumen works, in Tropical Dairy Farming: Feeding Management for Small Holder Dairy Farmers in the Humid Tropics. Landlinks Press. Victoria, Australia.

Murphy, G. M. and J. A. Connell. 1970. A simple method of collecting saliva to determine the sodium status of cattle and sheep. Aust. Vet. J. 46:595-598.

Noziere, P., F. Glasser, C. Loncke, I. Ortigues Marty, J. Vernet and D. Sauvant. 2011. Modelling rumen volatile fatty acids and its evaluation on net portal fluxes in ruminants, in Modelling Nutrient Digestion and Utilisation in Farm animal, ed. by Sauvant D., J. Van Milgen, P. Faverdin and N. Friggens. Wageningen Academy Publishers. pp. 158-167.

National Research Council (NRC). 2001. Nutrient Requirements of Dairy Cattle (7th rev. edn). National Academy Press, Washington, DC.

Odensten, M. O., Y. Chilliard and K. Holtenius. 2005. Effects of two different feeding strategies during dry-off on metabolism in high-yielding dairy cows. J. Dairy Sci., 88:2072-2082.

Oldham, J. D. 1984. Protein-energy interrelationships in dairy cows. J. Dairy Sci. 67:10901114.

Palmquist, D. L. 2006. Milk fat: Origin of fatty acids and influence of nutrition factors thereon, in Advanced Dairy Chemistry (Vol.2), ed. by Fox, P. F. and P. L. H. McSweeney Springer, New York.

Pattamanont, P. and S. Ruengpaibul. 2015. Fertility and milk production of dairy cattle rearing in good management farm, Research Paper Number 58(2)-0211-006. Bureau of Livestock Extension and Development. Bangkok, Thailand (in Thai).

Rahnema, S. H. and J. Fontenot. 1986. Effect of potassium on association of minerals with various fractions of digesta and feces of sheep fed hay. J. Anim. Sci. 63:1491-1501. 
Renkema, J. A., T. Senshu, B. D. E. Gaillard and E. Brouwer. 1962. The activity of the intestinal wall of the cow in sodium homeostasis. Netherlands J. Agri. Sci. 10:52-57.

Rhoads, M. L., R. P. Rhoads, M. J. VanBaale, R. J. Collier, S. R. Sanders, W. J. Weber, B. A. Crooker and L. H. Baumgard. 2009. Effects of heat stress and plane of nutrition on lactating Holstein cows: I. Production, metabolism, and aspects of circulating somatotropin. J. Dairy Sci. 92:1986-1997.

Rogers, J. A. and C. L. Davis. 1982. Effects of intraruminal infusions of mineral salts on volatile fatty acid production in steers fed high-grain and high-roughage diets. J. Dairy Sci. 65:953-962.

Rogers, J. A., C. L. Davis and J. H. Clark. 1982. Alteration of rumen fermentation, milk fat synthesis, and nutrient utilization with mineral salts in dairy cows. J. Dairy Sci. 65:577-586.

Ropstad, E., L. Vik-Mo and A. O. Refsdal, 1989. Levels of milk urea, plasma constituents and rumen liquid ammonia in relation to the feeding of dairy cows during early lactation. Acta Vet. Scand. 30:199-208.

Sanchez, W. K., M. A. McGuire and D. K. Beede. 1994. Macromineral nutrition by heat stress interactions in dairy cattle: review and original research. J. Dairy Sci. 77:20512079.

Schneider, P. L., D. K. Beede and C. J. Wilcox. 1986. Responses of lactating cows to dietary sodium source and quantity and potassium quantity during heat stress. J. Dairy Sci. 69:99-110.

Schneider, P. L., D. K. Beede and C. J. Wilcox. 1988. Effects of supplemental potassium and sodium chloride salts on ruminal turnover rates, acid-base and mineral status of lactating dairy cows during heat stress. J. Anim. Sci. 66:126-135.

Schneider, P. L., D. K. Beede, C. J. Wilcox and R. J. Collier. 1984. Influence of dietary sodium and potassium bicarbonate and total potassium on heat-stressed lactating dairy cows. J. Dairy Sci. 67:2546-2553.

Schonewille, J. T. and A. C. Beynen. 2005. Reviews on the mineral provision in ruminants (V), in CVB Documentation Report Nr. 37, Central Bureau for Livestock Feeding, Lelystad, The Netherlands.

Seangjun, A., S. Koonawootrittriron and M. A. Elzo. 2009. Characterization of lactation patterns and milk yield in a multibreed dairy cattle population in the central Thailand. Kasetsart J. 43:74-82. 
Shalit, U., E. Maltz, N. Silanikove and A. Berman. 1991. Water, sodium, potassium, and chlorine metabolism of dairy cows at the onset of lactation in hot weather. J. Dairy Sci. 74:1874-1883.

Shrivastava , B., S. Thakur, Y. P. Khasa, A. Gupte, A. K. Puniya and R. C. Kuhad. 2011. White-rot fungal conversion of wheat straw to energy rich cattle feed. Biodegradation. 22:823-831.

Silanikove, N., E. Maltz, A. Halevi and D. Shinder. 1997. Metabolism of water, sodium, potassium, and chlorine by high yielding dairy cows at the onset of lactation. J. Dairy Sci. 80:949-956.

Silanikove, N., E. Maltz, D. Shinder, E. Bogin, T. Bastholm, N. J. Christensen and P. Norggarrd. 1998. Metabolic and productive responses of dairy cows to increased ion supplementation at early lactation in warm weather. J. Dairy Res. 65:529-543.

Suttle, N. F. and A. C. Field. 1967. Studies on magnesium in ruminant nutrition 8. Effect of increased intakes of potassium and water on the metabolism of magnesium, phosphorus, sodium, potassium and calcium in sheep. Br. J. Nutr. 21:819-931.

Thai Milk Board. 2016. Standard Price for Raw Milk 2016. Ministry of Agriculture and Cooperatives, Bangkok, Thailand.

Thiangtum, W., A. Yawongsa, J. T. Schonewille, T. Rukkwamsuk, C. Yuangklang, M. W. A. Verstegen and W. H. Hendriks. 2011. An attempt to define the sodium requirement of lactating dairy cows in a tropical environment. J. Sci. Food Agric. 91:2333-2337.

Thiangtum, W., J. T. Schonewille, M. W. A. Verstegen, S. Arsawakulsudhi, T. Rukkwamsuka and W. H. Hendriks. 2017. Response of saliva Na/K ratio to changing Na supply of lactating cows under tropical conditions. J. Sci. Food Agric. 97:24802486.

Underwood, E. J. and N. F. Suttle. 1999. Sodium and chlorine, in The Mineral Nutrition of Livestock (3rd edn). CABI, New York, NY, pp. 185-229.

Van Weerden, E. J. 1959. Over de osmotische waarde en de gehalten aan enige opgeloste bestanddelen van de darminhoud en de mest bij het rund, in Verband Gebracht met de Resorptie der Mineralen. Thesis, Rijksuniversiteit Utrecht, Utrecht, The Netherlands (in Dutch).

West, J. W. 1994. Interactions of energy and bovine somatotropin with heat stress. J. Dairy Sci. 77:2091-2102.

Wu, Z. and L. D. Satter. 2000. Milk production during the complete lactation of dairy cows fed diets containing different amounts of protein. J. Dairy Sci. 83:1042-1051. 
Yaemkong, S., S. Koonawootrittriron, M. A. Elzo and T. Suwanasopee. 2010. Milk quantity, quality and revenue in dairy farms supported by a private organization in Central Thailand. Livest. Res. Rural Del. 22:2 Available at http://www.lrrd.org/lrrd22/2/yeam22033.htm 
Summary 
Dairy cows in Thailand are Holstein Friesian crossbreds $(87.5 \% \mathrm{HF})$ and it is generally accepted that current milk yields of these cows are below their potential. The main reason for the low milk production of these dairy cows in Thailand is related to the prevailing environmental conditions. The tropical climate is an important constraint for milk production because of two main reasons. First, it is well known that the digestibility of forages is negatively affected by tropical conditions. Unfavorable growth conditions can result in low contents of protein and minerals in the plant and high amounts of so called structural carbohydrates. Secondly, heat stress affects animal performance by affecting feed intake.

The objectives of this thesis were to provide a basis for improvement of milk production in small farm holders in Thailand through supplementation of protein and salt $(\mathrm{NaCl})$. Four experimental objectives were identified for this research, and it was anticipated that the outcome of the research can be applied so as to improve dairy production in Thailand and potentially other countries where dairy cows are maintained under tropical conditions.

In Chapter 2, a preliminary investigation is described into the relationship between ration composition and milk production of dairy cows in Thailand. The positive correlation between milk yield and crude protein (CP) intake was high during early lactation $(r=0.65)$. Cows consumed 5 and $8 \%$ greater $\mathrm{CP}$ than requirement during early- and mid-lactation, respectively. Interestingly, significant positive correlations were found between $\mathrm{Na}$ intake and milk yield. This observations is somewhat difficult to explain as Na intake was highly correlated with concentrate intake $(r=0.66)$. In other words, the increased milk yield may been related to a higher intake of $\mathrm{Na}$ but this was confounded with the amount of concentrate intake. In conclusion, protein, non-fibre carbohydrates and $\mathrm{Na}$ intake may have limited milk production by dairy cows on the Thai farms participating in the current study.

The study in Chapter 3 investigated the Na requirement of lactating dairy cows under tropical conditions by measuring $\mathrm{Na}$ in saliva, milk and faeces. The $\mathrm{Na}$ intake did not change the concentrations of $\mathrm{Na}$ and $\mathrm{K}$ in milk, faeces and serum, but did affect sodium concentration in the saliva. This observation was corroborated by the salivary $\mathrm{Na}$ and $\mathrm{K}$ concentrations with the cows on the low $\mathrm{NaCl}$ diet having a salivary $\mathrm{Na}$ concentrations $<120$ $\mathrm{mmol} / \mathrm{L}$ in combination with salivary $\mathrm{K}$ concentrations $>20 \mathrm{mmol} / \mathrm{L}(P<0.05)$. The ratio of $\mathrm{Na}: \mathrm{K}$ in saliva was a good indicator of $\mathrm{Na}$ intake by dairy cattle. Consumption of a daily ration formulated to contain the current $\mathrm{Na}$ requirement as set by the NRC appears to be too high for lactating cows under tropical conditions. A tentative value of $1.2 \mathrm{~g} \mathrm{Na} / \mathrm{kg} \mathrm{DM}$ is proposed as the $\mathrm{Na}$ requirement for dairy cows under tropical conditions. 
In Chapter 4, the assessment of the $\mathrm{Na}$ requirement of heat stressed lactating cows is hindered by accurate estimates of the Na losses through sweat. Direct studies, therefore, are needed on the time course of healthy animals to become $\mathrm{Na}$ depleted and the subsequent rate of repletion. The rate of $\mathrm{Na}$ depletion and subsequent rate of $\mathrm{Na}$ repletion with two levels of dietary $\mathrm{Na}$ to lactating dairy cows housed under tropical conditions was investigated using the salivary $\mathrm{Na} / \mathrm{K}$. The 12 lactating cows rapidly developed clinical signs of $\mathrm{Na}$ deficiency, including pica, polyuria and polydipsia, reduced body weight and reduced milk yield when fed a Na-low (0.33 g/kg DM) ration during 3 weeks. Deficiency symptoms were associated with a rapid decrease in salivary $\mathrm{Na} / \mathrm{K}$ ratio to $<4.3$ from 7-21 d. Subsequent repletion of the cows with $\mathrm{NaCl}$ to a ration concentration of 1.1 or $1.6 \mathrm{~g} \mathrm{Na} / \mathrm{kg} \mathrm{DM}$ for 5 weeks did not restore salivary $\mathrm{Na} / \mathrm{K}$ ratio to values of $>6$. A daily $\mathrm{Na}$ intake of heat-stressed lactating cows to a ration intake of $1.6 \mathrm{~g} \mathrm{Na} / \mathrm{kg} \mathrm{DM}$ was insufficient to restore $\mathrm{Na}$ deficiency. One week was sufficient to deplete heat-stressed lactating cows of $\mathrm{Na}$ allowing for rapid dose-response studies utilizing the salivary $\mathrm{Na} / \mathrm{K}$ ratio as a parameter for $\mathrm{Na}$ status of cows under tropical conditions.

In Chapter 5, an experiment is reported where the effects of two levels of dietary CP in concentrates with similar proportions of rumen undegradable protein (RUP) on rumen metabolism, milk yield and composition in mid lactating cows was investigated. Concentrate feeds were formulated to provide low dietary CP [17.3\%; LCP] or high dietary CP [19.0\%; $\mathrm{HCP}$. The proportion of rumen degradable protein and RUP was $61 \%$ and $39 \%$ in both diets, respectively. Diets were isocaloric in terms of net energy for lactation. Milk yield, milk lactose yield, dry matter intake (DMI), and apparent digestibility of DM, CP and neutral detergent fibre (NDF) were greater in cows fed the HCP than in those fed the LCP. Concentration of blood urea nitrogen $(\mathrm{N})$ was elevated in cows fed HCP diets. Rumen ammonia- $\mathrm{N}$ concentration and $\mathrm{pH}$ tended to increase in cows fed the HCP diet. Rumen microorganism counts and volatile fatty acids levels in the rumen did not differ between treatments. In conclusion, increasing CP content in mid-lactating cow was beneficial to increase DMI, apparent digestibility of DM, CP and NDF and therefore milk yield.

In Chapter 6, the results of the experimental studies reported in this thesis are discussed in light of Thai dairy production conditions. 
บทสรุป

โคนมในประเทศไทยส่วนใหญ่เป็นโคนมพันธุ์โฮลสไตน์ฟรีเชียนที่มีสายเลือดของโคนมพันธุ์แท้อยู่ $87.5 \%$ แต่ ความสามารถในการผลิตน้ำนมต่ำกว่าความสามารถของพันธุกรรมที่ผลิตนมได้ สาเหตุหลักมาจากภูมิอากาศของ ประเทศเป็นแบบเขตร้อนชื้น สภาพอากาศดังกล่าวทำให้พืชอาหารหยาบมีคุณภาพต่ำส่งผลให้เกิดการย่อยยาก เนื่องจากมีองค์ประกอบของเยื่อใยสูง มีปริมาณโปรตีนและแร่ธาตุต่ำ นอกจากนี้ความเครียดเนื่องจากความร้อนยัง ส่งผลต่อประสิทธิภาพโคนมโดยทำให้การกินได้ของโคลดลง

วิทยานิพนธ์นี้มีวัตถุประสงค์เพื่อเป็นข้อมูลพื้นฐานในการปรับปรุงการผลิตน้ำนมในฟาร์มโคนมรายย่อย ของประเทศไทย โดยการศึกษาเรื่องการเสริมโปรตีนและเกลือในอาหาร ซึ่งประกอบด้วย 4 เรื่องการศึกษา จากผล การศึกษานี้หวังว่าจะสามารถนำไปประยุกต์ใช้ในฟาร์มโคนมที่เลี้ยงในเขตร้อนชื้นเพื่อช่วยเพิ่มผลผลิตน้ำนม

บทที่ 2 เป็นการศึกษาเบื้องต้นเกี่ยวกับความสัมพันธ์ระหว่างองค์ประกอบอาหารและผลผลิตน้ำนมของโค นมในประเทศไทย พบว่าปริมาณน้ำนมในช่วงต้นของการให้นมมีความสัมพันธ์ในเชิงบวกกับปริมาณโปรตีนที่โค ได้รับ $(\mathrm{r}=0.65)$ โดยแม่โคที่อยู่ในระยะต้นและระยะกลางของการให้นมที่ได้รับโปรตีนมากกว่าค่าความต้องการ โปรตีนระดับมาตรฐานอยู่ $5 \%$ และ $8 \%$ ตามลำดับ และยังพบว่าปริมาณโซเดียมที่โคได้รับมีความสัมพันธ์ในเชิง บวกกับปริมาณน้ำนม $(\mathrm{r}=66)$ แต่ความสัมพันธ์นี้อาจไม่ใช่ความสัมพันธ์ที่แท้จริงเนื่องจากปัจจัยกวนจากปริมาณ อาหารข้นซึ่งมีโซเดียมเป็นองค์ประกอบอยู่ค่อนข้างมาก โดยสรุปจากการศึกษาพบว่าปริมาณโปรตีน คาร์โบไฮเดรตที่ไม่ใช่เยื่อใย และโซเดียมที่โคได้รับ อาจส่งผลต่อการผลิตน้ำนมในประเทศไทย บทที่ 3 เป็นการศึกษาความต้องการโซเดียมของโครีดนมในเขตร้อนชื้น โดยการวัดระดับโซเดียมใน น้ำลาย น้ำนม และมูล พบว่าปริมาณการกินโซเดียม ไม่ส่งผลต่อความเข้มข้นของโซเดียมและโปแทสเซียมใน น้ำนม มูล และซีรั่ม แต่ส่งผลต่อความเข้มข้นของโซเดียมในน้ำลาย พบว่าโคนมที่กินอาหารที่มีเกลือ $(\mathrm{NaCl})$ ใน ระดับต่ำ จะมีความเข้มข้นของโซเดียมในน้ำลายน้อยกว่า 120 มิลลิโมลต่อลิตร และมีความเข้มข้นของโปแทสเซียม ในน้ำลายมากกว่า 20 มิลลิโมลต่อลิตร $(P<0.05)$ สัดส่วนของโซเดียมต่อโปแทสเซียมในน้ำลายเป็นตัวบ่งชี้ที่ดีของ ปริมาณโซเดียมที่โคได้รับ จากการศึกษาครั้งนี้พบว่าความต้องโซเดียมที่กำหนดโดย $\mathrm{NRC}$ สูงกว่าความต้องการของ โครีดนมที่อยู่ในเขตร้อนชื้น ซึ่งมีความต้องการ โซเดียม 1.2 กรัมต่อกิโลกรัมวัตถุแห้ง 
บทที่ 4 เป็นการศึกษาความต้องการโซเดียมของโครีดนมที่อยู่ในภาวะความเครียดจากความร้อน โดยนำ การสูญเสียโซเดียมทางเหงื่อมาร่วมคำนวณด้วย ทำการศึกษาในโครีดนม 12 ตัวให้อยู่ในภาวะขาดโซเดียม $(0.33$ กรัมต่อกิโลกรัมวัตถุแห้ง) เป็นระยะเวลา 3 สัปดาห์ พบว่าโคทั้งหมดแสดงอาการขาดโซเดียม โคกินน้ำและขับ ปัสสาวะมาก น้ำหนักตัวและปริมาณนมลดลง ร่วมกับการลดลงของสัดส่วนโซเดียมต่อโปแทสเซียมในน้ำลายน้อย กว่า 4.3 ในระหว่างวันทดลองที่ $7-21$ และหลังจากนั้นทำการแบ่งโคเป็น 2 กลุ่ม เพื่อทดแทนโซเดียมในระดับต่ำ (1.1 กรัมต่อกิโลกรัมวัตถุแห้ง) และระดับสูง (1.6 กรัมต่อกิโลกรัมวัตถุแห้ง) เป็นระยะเวลา 5 สัปดาห์ ผลกศึกษา พบว่าการทดแทนโซเดียมทั้ง 2 กลุ่ม ไม่สามารถทำให้สัดส่วนโซเดียมต่อโปแทสเซียมในน้ำลาย กลับมามีสัดสัดที่ มาก 6 โดยสรุปสัดส่วนโซเดียมต่อโปแทสเซียมในน้ำลายสามารถบ่งชี้ภาวการณ์ขาดโซเดียมได้ภายใน 7 วัน

บทที่ 5 เป็นการศึกษาเมตาบอลิซึมในกระเพาะรูเมน ปริมาณนม และองค์ประกอบน้ำนมของโครีดนม ระยะกลาง โดยทดลองให้อาหารข้นที่มีโปรตีนต่างกัน 2 ระดับคือระดับต่ำ $(17.3 \%)$ และระดับสูง $(19.0 \%)$ ซึ่งมี สัดส่วนของโปรตีนไหลผ่านในอาหาร (RUP, 39\%) และพลังงานสุทธิในการให้น้ำนมเท่ากัน ผลการทดลองพบว่า ปริมาณน้ำนม ปริมาณแลคโตส ปริมาณการกินได้ที่คิดเป็นวัตถุแห้ง และการย่อยได้ปรากฎของวัตถุแห้ง โปรตีน และเยื่อใยที่ละลายในสารฟอกที่เป็นกลาง (NDF) ในโคที่ได้รับโปรตีนระดับสูงจะสูงกว่าในโคที่ได้รับโปรตีน ระดับต่ำ ความเข้มข้นของยูเรียในกระแสเลือดเพิ่มขึ้นในโคที่ได้รับโปรตีนระดับสูง โดยที่ความเข้มข้นของ แอมโมเนียไนโตรเจน และความเป็นด่างในกระเพาะรูเมนมีแนวโน้มมีค่าสูงขึ้นในโคที่ได้รับโปรตีนระดับสูง ปริมาณโปรตีนในอาหารไม่ส่งผลต่อจำนวนจุลชีพ และ กรดไขมันระเหยง่ายในกระเพาะรูเมน โดยสรุปการเพิ่มขึ้น ของโปรตีนในอาหารโคนมระยะกลางส่งผลต่อการเพิ่มขึ้นของการกินได้ของวัตถุแห้ง การย่อยได้ปรากฏของวัตถุ แห้ง โปรตีน $\mathrm{NDF}$ และปริมาณน้ำนม

บทที่ 6 ผลการศึกษาทั้งหมดที่อยู่ในวิทยานิพนธ์นี้ได้ถูกนำมาอภิปรายภายใต้สภาพการเลี้ยงโคนมใน ประเทศไทย 
Acknowledgments 
I would like to acknowledge and express my sincere gratitude to those who helped and supported me during my Ph.D. study. Because of the length of the journey of my Ph.D., there are many people who have been involved. I am sorry if I omitted someone's name here.

I would like to pay special thanks and grateful appreciation to people and organizations mentioned below:

Prof. Dr. Ir. Anton Beynen, Assoc. Prof. Dr. Theera Rukkwamsuk and Dr. Robert Paling who initiated my inspiration to get involved in the Ph.D. program.

Prof. Dr. Ir. Wouter H. Hendriks, Dr. Thomas Schonewille and Prof. Dr. Ir. Martin W. A. Verstegen who gave me the opportunity to continue my studies in Wageningen University and supported me in the conduct of the studies and in every bit of writing Ph.D. dissertation, without their support it would have been impossible for me to accomplish my Ph.D.

Assoc. Prof. Dr. Jeerachai Kanjanapruthipong and Asst. Prof. Dr. Chalermpon Yuangklang who gave me valuable advice and supported me throughout my studies.

My colleagues, the staff at Kasetsart University Veterinary Demonstration Farm, Miss Suvimon Pratummanee and Mr. Sitthiporn Phothitheerabut who supported and helped to collect samples and Mrs. Siriluk Jara who provided me access to the laboratory.

Mariet and Martin Verstegen who provided me extensive personal help and guidance and taught me a great deal of both in terms of scientific research and living life in general.

The Faculty of Veterinary Medicine, Kasetsart University and Utrecht University for partial financial support of my Ph.D. program and Animal Nutrition Group, Wageningen University $\&$ Research for financial support of publishing my dissertation.

Finally, my parents and my siblings who have been continually staying at my side and given me moral and emotional support all these years, as well as all of my friends who have supported me along the way. The most important person that I want to give special thanks to, is my beloved husband who always loves and supports me with everything I do/needed. 


\section{About the author}

Curriculum vitae

List of publications 


\section{ABOUT THE AUTHOR}

Wandee Thiangtum was born on October 21, 1970 in Chanthaburi province, Thailand. She obtained the degree of Doctor of Veterinary Medicine (D.V.M.) in 1996 from Kasetsart University, Thailand. After her graduation, she worked for 8 months as a small animal practitioner at Kasetsart University Veterinary

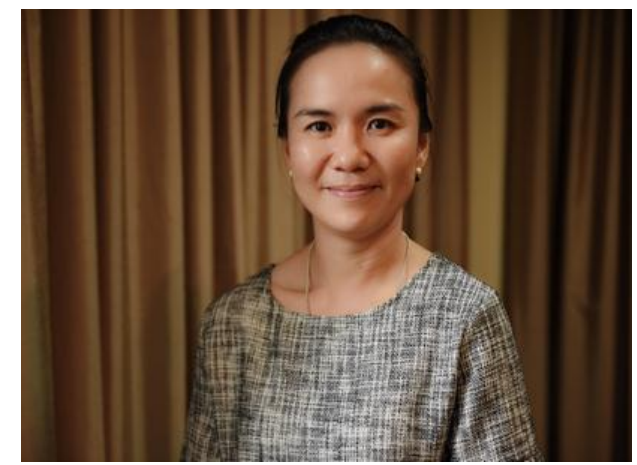
Teaching Hospital at the Kamphaeng Saen campus. Thereafter she became a staff member at the Large Animal and Wildlife Clinical Sciences, Faculty of Veterinary Medicine, Kasetsart University. In 2004, she received a M.Sc. degree in Veterinary Epidemiology and Economics from Utrecht University, the Netherlands. That same year, she started her Ph.D. studies through a sandwich program with Faculty of Veterinary Medicine, Utrecht University and made the switch in continuing her studies at the Animal Nutrition Group, Wageningen University \& Research in 2010. She has been promoted to an Assistant Professor in 2013. During the Ph.D. program she started preliminary experiments and conducted her research work focusing on sodium and protein requirement of lactating cows under tropical conditions. This thesis provides information on the work she did during her Ph.D. and was defended in public on May 7, 2018, at Wageningen University \& Research, the Netherlands. 


\section{LISTS OF PUBLICATIONS}

\section{Paper publications}

Thiangtum, W., A. Yawongsa, J .T. Schonewille, T. Rukkwamsuk, C. Yuangklang, M. W. A. Verstegen, W. H. Hendriks. 2011. An attempt to define the sodium requirement of lactating dairy cows in a tropical environment. J. Sci. Food Agric. 91: 2333-2337.

Thiangtum, W., S. Kananub, C. Sujaritthanyakul. 2013. Association between urine pH and subclinical hypocalcaemia among periparturient dairy cows in Western part of Thailand. Chiang Mai Vet. J. 11: 3-8.

Thiangtum, W., J. Th. Schonewille, A. Yawongsa, T. Rukkwamsuk, J. Kanjanapruthipong, M. W. A. Verstegen and W. H. Hendriks. 2014. Effect of Dietary Protein Levels on Rumen Metabolism and Milk Yield in Mid-Lactating Cows under Hot and Humid Conditions. J. Anim. Vet. Adv. 13:9-14.

Tokita, N., A. Shirasaka, W. Thiangtum, N. Ratanapob, Y. Kawamoto and T. Tokita. 2015. Potential digestibility of tropical grasses for swamp buffalo (Bubalus bubalis) in Thailand. Asian J. Plant Sci. Res. 5:32-37.

Thiangtum, W., J. Th. Schonewille, M. W. A. Verstegen, S. Arsawakulsudhi, T. Rukkwamsuk and W. H. Hendriks. 2017. Response of saliva Na/K ratio to changing Na supply of lactating cows under tropical conditions. J. Sci. Food Agric. 97: 24802486.

\section{Conferences and symposia proceedings}

Rungrattanaubol, W., K. Nantaklang, J. Rattanachunuprakan, T.Musikacharoen, A. Yawongsa, V. Boonyawiwat, N. Tongthip, J. Wongsanit, and P. Arunwipas. Retrospective study of Hematological findings from cattle with Babesiosis. 1999. in Proceeding of 25th Annual Conference of the Thai Veterinary Medical Association under Royal Patronage. 27-29 October, 1999. pp. 333-336.

Wajjwalku, W., S. Kasemsuwa, W. Chumsing, J. Wongsanit, A. Yawongsa, K. Tancharoen, N. Tongthip, W. Rungrattanaubol, and T. Pinyopummintr. Isolation of foot and mouth disease virus from clinical cases.1999. in Proceeding of 37th Annual Conference of Kasetsart University. 3-5 February, 1999. pp. 117. 
Musikacharoen, T., W. Wajjwalku, W. Chumsing, K, Wonghong, B. Tirapat, W. $\underline{\text { Rungrattanaubol, }}$ and M. Ookwaha. Establishment B95ab cell line for isolation of canine distemper virus and serum neutralization test.1999. in Proceeding of 37th Annual Conference of Kasetsart University. 3-5 February, 1999. pp. 118.

Yawongsa, A., W. Rungrattanaubol, and T. Rukkwamsuk. Relationship between urea nitrogen concentration in serum and milk of dairy cows. 2003. in Proceeding of 41st Annual Conference of Kasetsart University. 3-7 February, 2003. pp. 516-520.

Yawongsa, A., K. Jeenacharoen, W. Rungrattanaubol, and T. Rukkwamsuk. 2003. The use of heart girth length of estimate body weight in cross-bred Holstein Friesian. in Proceeding of 41st Annual Conference of Kasetsart University. 3-7 February, 2003. pp. 525-531.

Yawongsa, A., K. Jeenacharoen, W. Rungrattanaubol, and T. Rukkwamsuk. 2003. Reproductive performance of crossbred Holstein Friesian. in Proceeding of 41st Annual Conference of Kasetsart University. 3-7 February, 2003. pp. 521-524.

Rungrattanaubol, W., A. Yawongsa, T. Rukkwamsuk, S. Arsawakulsudhi, C. Yuangklang and A.C. Beynen. 2005. Effect of low versus high dietary crude protein on milk composition and milk yield in early and mid- lactating dairy cows. In Proceedings New Dietary Strategies to Improve Animal Health and Food Safety. Khon Khaen. Thailand. 16-17 November, 2005. pp. 64-69.

Thiangtum, W., A. Yawongsa, T. Rukkwamsuk, C. Yuangklang, J. T. Schonewille and A. C. Beynen. 2007. Influence varying dietary ratio of $\mathrm{NaCl}$ intake on excretion, blood and saliva concentration of sodium, potassium and chloride in lactating dairy cows. In Proceedings current research on feeds and feeding of ruminants in Tropical countries. Bangkok. Thailand, 15-16 October, 2007. pp. 35-39

Thiangtum W., J. Rattanakunuprakarn, S. Aunsiri, N. Muangthong, K. Jeenacharoen, A. Serbsai and K. Nanklang. Comparative hematology of cattle infected with Babesia sp., Anaplasma sp. and Trypanosome sp.: a retrospective study. In Proceedings International Conference on Asian meeting of animal medicine specialties (AMAMS). Asian Veterinary (1st Dermatology, 2nd Internal Medicine, 1st Surgery) Meeting. Taipei, Taiwan. December 11-13, 2009. 
Thiangtum, W., N. Ratanapob, S. Srisomrun, S. Kananub, C. Sujaritthanyakul, A. Khantaboot. Determination of serum calcium concentration in periparturient dairy cows. In Proceedings International Conference on Veterinary Science II CAB, APHIS, FAO Joint Symposiums “ASIA Web for World Food Security” Bangkok. Thailand, February 29-March 2, 2012. pp. 242-243.

\section{Training courses}

Dairy Medicine Workshop covering theoretical and practical aspects of milk quality and mastitis in machine milked dairy herds. By John G. Ryan Post Graduate Foundation in Veterinary Science. December 14-15, 1998.

Dairy Medicine Workshop covering theoretical and practical aspects of nutrition in dairy herds in Thailand. By John G. Ryan Post Graduate Foundation in Veterinary Science. 21-23 March, 1999.

Animal Production and Veterinary Public Health. Utrecht, The Netherlands from 13 March to 28 April, 2000.

Nutrition Based on Local Feedstuffs in Ruminant Production and Health. Khon Khaen, Thailand. Asia-link program from 21 April - 2 May, 2008.

Advanced Methods for Increasing Dairy Yield: Small and Large Animal. The Hebrew University of Jerusalem Rehovot Campus, Israel from 2-26 May, 2011. 


\section{Colophon}

The research described in this thesis was financially supported by the Faculty of Veterinary Medicine, Kasetsart University, Thailand, Utrecht University and Wageningen University \& Research, the Netherlands.

Cover design by Saranya Saichan and Soammarisa Paungpornsri

Cow picture ID 10190794 by VectorStock ${ }^{\circledR}$ (203155)

Salt icon by Flaticon

Printed by Digiforce, Proefschriftmaken.nl 